Andrews University

Digital Commons @ Andrews University

\title{
An Integration of Quality Assurance and Existing Worship Components: A Model to Improve Worship in the Small Seventh- day Adventist Church
}

Nelson Fernando de Oliveira

Andrews University

Follow this and additional works at: https://digitalcommons.andrews.edu/dmin

Part of the Practical Theology Commons

\section{Recommended Citation}

de Oliveira, Nelson Fernando, "An Integration of Quality Assurance and Existing Worship Components: A Model to Improve Worship in the Small Seventh-day Adventist Church" (2002). Professional Dissertations DMin. 603.

https://dx.doi.org/10.32597/dmin/603

https://digitalcommons.andrews.edu/dmin/603

This Project Report is brought to you for free and open access by the Graduate Research at Digital Commons @ Andrews University. It has been accepted for inclusion in Professional Dissertations DMin by an authorized administrator of Digital Commons @ Andrews University. For more information, please contact repository@andrews.edu. 


\section{ABSTRACT}

AN INTEGRATION OF QUALITY ASSURANCE AND EXISTING WORSHIP COMPONENTS: A MODEL TO IMPROVE WORSHIP IN THE SMALL SEVENTH-DAY ADVENTIST CHURCH

by

Nelson Fernando de Oliveira Jr.

Adviser: Lilianne Doukhan 
ABSTRACT OF GRADUATE STUDENT RESEARCH

Dissertation

Andrews University

Seventh-day Adventist Theological Seminary

Title: AN INTEGRATION OF QUALITY ASSURANCE AND EXISTING

WORSHIP COMPONENTS: A MODEL TO IMPROVE WORSHIP

IN THE SMALL SEVENTH-DAY ADVENTIST CHURCH

Name of researcher: Nelson Fernando de Oliveira Jr.

Name and degree of faculty adviser: Lilianne Doukhan, Ph.D.

Date completed: July 2002

\section{Problem}

Corporate worship is an experience that needs to be relevant to all. Small-church leaders face the challenge of transforming existing worship components into a more dynamic service, and increasing member involvement. Leaders at small churches have been known to express frustration trying to improve lives, and to worship in spirit and truth. Currently, there is little or no interface between the Seventh-day Adventist (SDA) components of the worship service (e.g., music, offering, preaching, and Scripture reading) and current discussions of quality assurance in relationship to a more vibrant corporate worship experience. There is a need to develop a model to revitalize worship in the small SDA church. 


\section{Method}

This study presents a survey of biblical principles for corporate worship as well as official guidelines and suggestions for worship practices of the small SDA church. It integrates suggestions from current literature on worship and quality assurance with the APIE model for worship service improvement. This model is designed to assist the leaders of small churches to Assess, Plan, Implement, and Evaluate the needs of their congregation within the corporate worship experience. Consequently, this project will integrate the proposed APIE model with actual worship practices.

\section{Conclusions}

The ultimate goal of this project is to assist small churches to have more profundity and variety, achieve more lay involvement, and improve the worshiper's ability to understand and communicate the Gospel message. It also should improve the quality of worship service in the small SDA church. The principles specified in this dissertation could be used to meet similar needs in other parts of the world. 
Andrews University

Seventh-day Adventist Theological Seminary

AN INTEGRATION OF QUALITY ASSURANCE AND EXISTING WORSHIP COMPONENTS: A MODEL TO IMPROVE WORSHIP

IN THE SMALL SEVENTH-DAY ADVENTIST CHURCH

\author{
A Dissertation \\ Presented in Partial Fulfillment \\ of the Requirements for the Degree \\ Doctor of Ministry
}

by

Nelson Fernando de Oliveira Jr.

July 2002 



\title{
AN INTEGRATION OF QUALITY ASSURANCE AND EXISTING WORSHIP COMPONENTS: A MODEL TO IMPROVE WORSHIP IN THE SMALL SEVENTH-DAY ADVENTIST CHURCH
}

\author{
A dissertation \\ presented in partial fulfillment \\ of the requirements for the degree \\ Doctor of Ministry
}

by

Nelson Fernando de Oliveira Jr.

APPROKAL BY THE COMMITTEE:

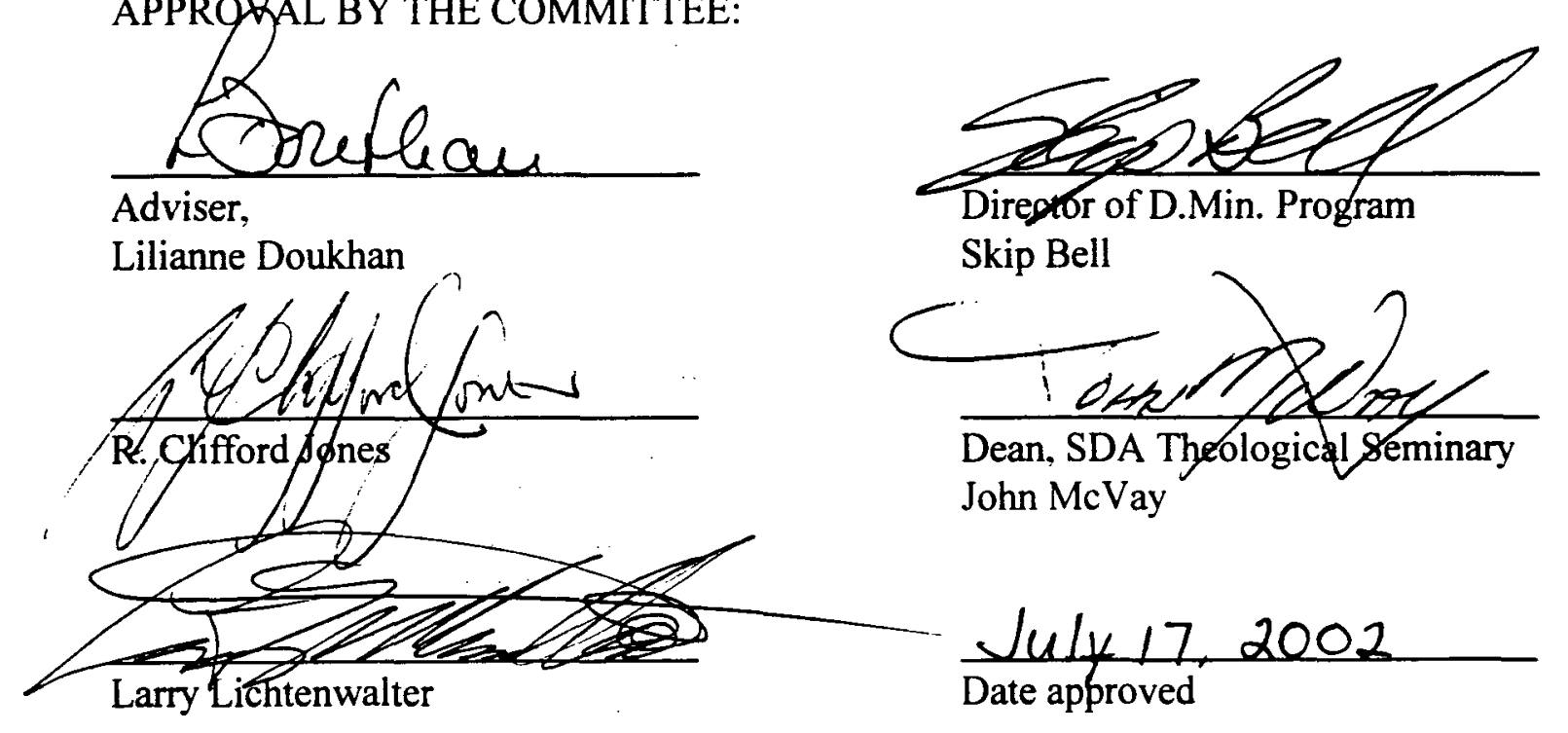




\section{TABLE OF CONTENTS}

ACKNOWLEDGMENTS $\ldots \ldots \ldots \ldots \ldots \ldots \ldots \ldots \ldots \ldots \ldots \ldots \ldots$ vi

Chapter

1. INTRODUCTION $\ldots \ldots \ldots \ldots \ldots \ldots \ldots \ldots \ldots \ldots \ldots \ldots \ldots \ldots \ldots$

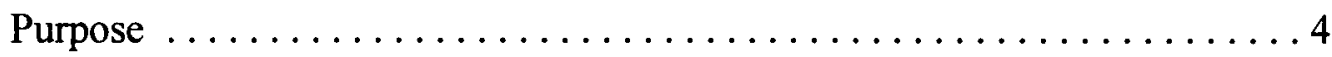

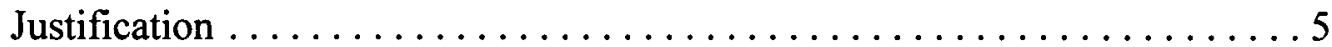

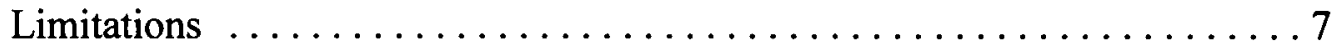

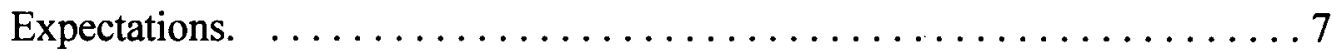

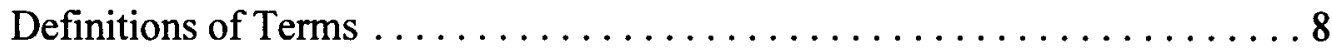

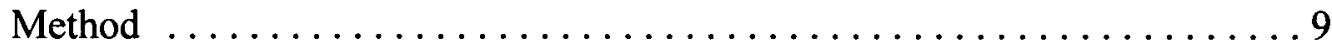

2. THEOLOGICAL AND BIBLICAL PRINCIPLES OF. CORPORATE WORSHIP $\ldots \ldots \ldots \ldots \ldots \ldots \ldots \ldots \ldots \ldots \ldots \ldots$

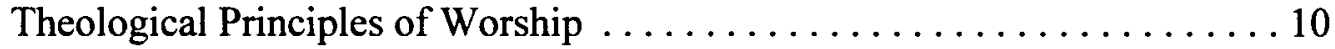

Biblical Principles of Corporate Worship . . . . . . . . . . . . . 15

Corporate Worship in the Old Testament ................. 21

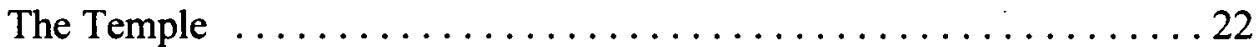

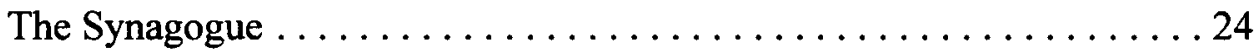

Corporate Worship in the New Testament . . . . . . . . . . . . 26

Empowerment Through the Holy Spirit . . . . . . . . . . . . . . 29

Jesus' Example .......................... 31

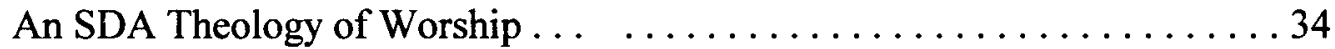

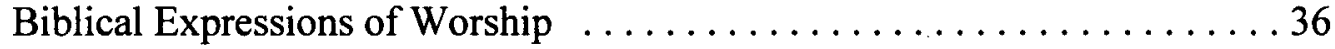

Summary . . . . . . . . . . . . . . . . . . . 38

3. WORSHIP IN THE SMALL SDA CHURCH: OFFICIAL GUIDELINES AND SUGGESTIONS

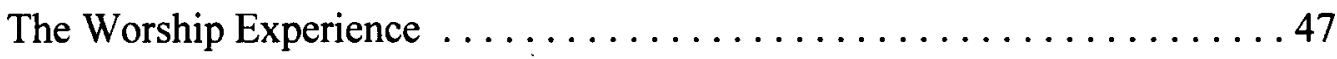

Description of Worship ........................ 49

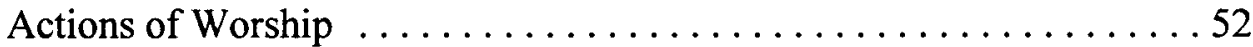

Challenges in Church Worship ..................... 54

The SDA Pioneers and Corporate Worship ................ 58 


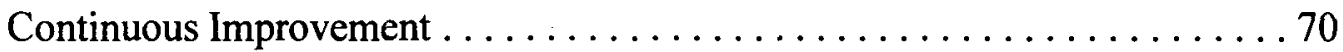

Step One: Assess the Worship Experience and Congregation ......... 76

Obstacles for Worship Improvement . . . . . . . . . . . . . . 77

Assessment Procedures ........................... 79

Step Two: Plan the Worship Service $\ldots \ldots \ldots \ldots \ldots \ldots \ldots \ldots \ldots \ldots . \ldots . \ldots 7$

A Biblical Approach to Planning . . . . . . . . . . . . . . . . 89

God Has a Plan for Us ....................... 89

God Is the Source to Achieve Plans $\ldots \ldots \ldots \ldots \ldots \ldots \ldots . \ldots 9$

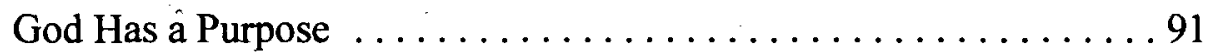

Visualization of the Complete Plan .................92

SDA Leadership Advice for Worship Planning ............. 93

Aspects of Planning ........................... 96

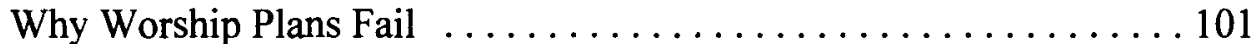

Steps in Organizing the Worship Service $\ldots \ldots \ldots \ldots \ldots \ldots \ldots 103$

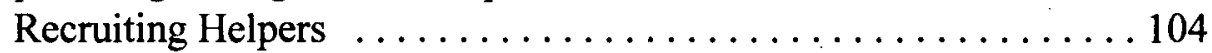

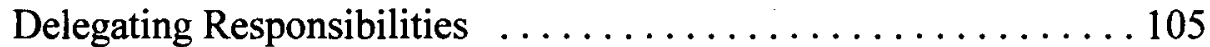

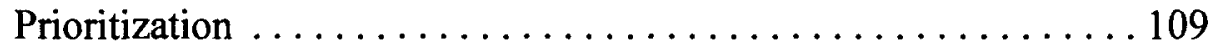

Step Three: Implement the Elements of Worship $\ldots \ldots \ldots \ldots \ldots \ldots \ldots 110$

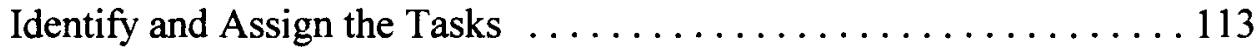

Train and Direct .................................. 113

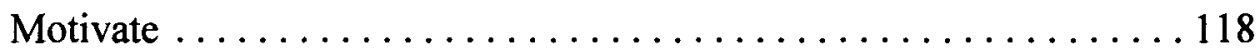

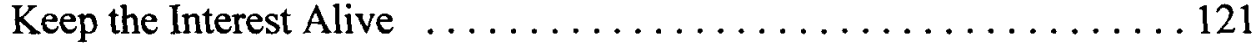

Recommendations for Leading in Worship ............. 122

Seven Cs for Successful Worship Service ............... 124

Step Four: Evaluate the Results in the Life of the Congregation . . . . . . . 126

The Biblical View of Evaluation and Performance .......... 127

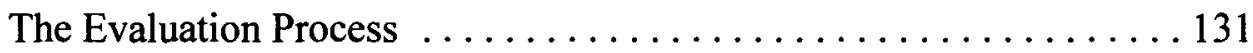

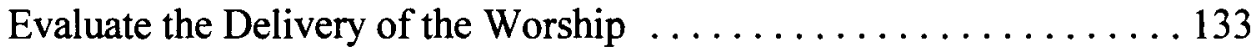

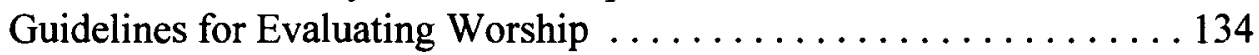

Avoid Reasons for Failure . . . . . . . . . . . . . . . . . 137

5. THE INTEGRATION OF APIE WITH CORPORATE WORSHIP

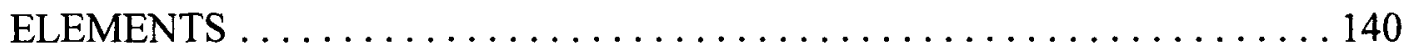

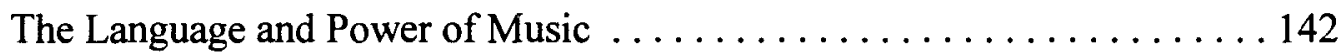

Worship Music in the World But Not of the World .......... 143

Reasons for Improving Music in Worship . . . . . . . . . . . 148

Practical Suggestions for Music Improvement . . . . . . . . . 149

The Power of Prayer in Corporate Worship ................ 154

Practical Advice for Public Prayer Improvement $\ldots \ldots \ldots \ldots \ldots 156$ 
The Importance of Scripture Reading in Worship ............. 162

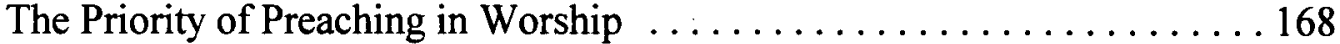

Preach from the Scripture ...................... 172

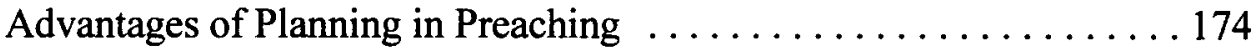

Making the Offering Meaningful ........................ 175

Children and Youth Involvement in Worship ............... 180

Practical Ideas for Involving Children and Youth in Worship ..... 184

Treating Youth as Real Worshipers .................. 187

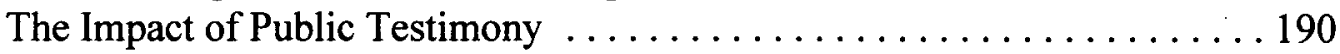

The Value of Benediction . . . . . . . . . . . . . . . . . . . 192

Conclusion ...................................... 195

6. SUMMARY, CONCLUSIONS, AND RECOMMENDATIONS . ........ 199

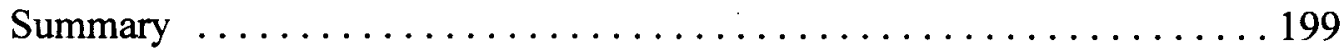

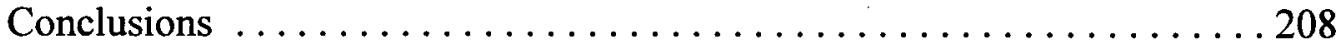

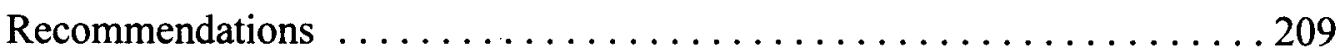

Appendices

A. WORSHIP ELEMENTS PRIORITIES $\ldots \ldots \ldots \ldots \ldots \ldots \ldots \ldots \ldots \ldots \ldots \ldots \ldots \ldots \ldots$

B. YOUR PERSONAL EVALUATION OF THE WORSHIP SERVICE

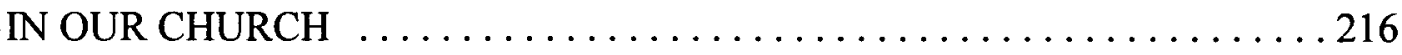

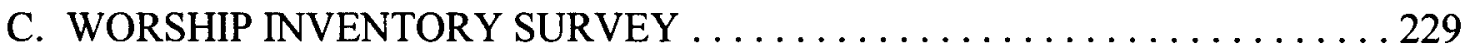

D. WORSHIP EXPERIENCE QUESTIONNAIRE $\ldots \ldots \ldots \ldots \ldots \ldots \ldots . \ldots 234$

E. WORSHIP SURVEY SAMPLE LETTER $\ldots \ldots \ldots \ldots \ldots \ldots \ldots \ldots \ldots 236$

F. WORSHIP PLANNING WORKSHEET $\ldots \ldots \ldots \ldots \ldots \ldots \ldots \ldots \ldots \ldots \ldots \ldots$

G. WORSHIP EVALUATION FOR THE LEADERS $\ldots \ldots \ldots \ldots \ldots \ldots \ldots 240$

H. WORSHIP SERVICE EVALUATION $\ldots \ldots \ldots \ldots \ldots \ldots \ldots \ldots \ldots \ldots \ldots \ldots \ldots \ldots \ldots$

I. MY ENCOUNTER WITH GOD $\ldots \ldots \ldots \ldots \ldots \ldots \ldots \ldots \ldots \ldots \ldots \ldots \ldots \ldots \ldots$

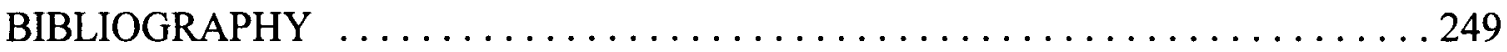

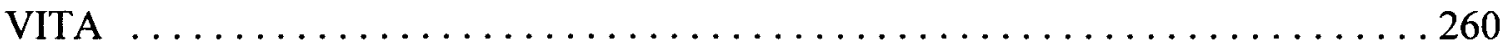




\section{ACKNOWLEDGMENTS}

I want to lift up God's name on high and express my gratitude for His faithfulness and extreme guidance; for giving me freedom to praise, worship, and serve Him.

I would like to express my gratitude to my friends for their encouragement and prayers and to several individuals who through their encouraging words and actions have made the completion of this project possible, meaningful, and inspiring.

Special gratitude needs to be given to my "fofinha" and lovely wife Najla who has been a wonderful inspiration, support, friend and lover, always together in life and ministry. Acknowledgment is owing also to our two children, Neander and Narlon, who motivate me to keep growing and learning the important lessons in life as well as for being my best friends.

I also wish to acknowledge my parents for their financial and spiritual support, and to certain church members of Sao Paulo, Curitiba, Porto Alegre, Brasilia, Provo and Vernal, the Sao Paulo Conference, the Central Brazil Union, the Nevada-Utah Conference, and the department of Pastoral Ministry at Andrews University—all have helped to make my dream a reality.

Finally, I would like to thank the members of my committee, Doctors Lilianne Doukhan, Clifford Jones, and Larry Lichtenwalter, for their guidance and appropriate suggestions. To all I give my sincere gratitude and appreciation. 


\section{CHAPTER 1}

\section{INTRODUCTION}

Corporate worship, the unification of God with His people, is an experience that needs to be relevant to all. Corporate worship is at the very center of the life of every church. It is in worship that a congregation gathers to share and express common beliefs. It is in worship that the individual Christian becomes aware that he or she is a part of a larger family of believers.

God expects some form of worship from His people, both individually and corporately. Consequently, pastors and church leaders must make every effort to integrate quality assurance and meaningful worship components to create a rich, meaningful corporate worship experience for all believers. All believers should be encouraged to participate in corporate worship improvement.

Where an individual approaches God, one on one, as a member of Christ's Body, corporate worship typically takes place as a church family function. This concept of corporate worship on earth is reflected in Scripture. In the Old Testament the whole assembly bowed in worship ( $2 \mathrm{Chr} 29: 28$ ). In the New Testament, the book of Acts refers to the believers meeting together in one place (2:1), devoting themselves to the apostles' teaching and fellowship (2:42); all who believed were together (2:44). The believers' 
worship experience became a proclamation experience so that others could have the same fellowship with the Father and with His Son, Jesus Christ (1 John 1:3).

Since corporate worship requires a connection between God and His people, churches would do well to avoid those worship practices that reflect a ministerial monopoly. In some churches, only ordained leaders are allowed to take responsibilities in the worship service and no involvement from lay people is present. Church leaders need to keep in mind that corporate worship is the service of God's people. It was never God's intent that authority (pastors, elders, church leaders) act as an intermediary between Him and His people. As George Barna points out, highly effective churches succeed in worship because they take seriously the responsibility of connecting people to God through worship, and they "have discovered the antidote to spiritual anemia: genuine, dynamic church wide worship."

During the corporate worship experience, worshipers must sense that they are participators and not just spectators. Not only are they to share in the hymns, prayers, and responsive readings, but lay members should be involved in the entire creative process of the worship service. The bounty borne from such participation will testify to the fact that leadership, in corporate worship, is not the exclusive privilege of men set apart by ordination. At the same time, the congregation will feel integrated and ready to interact in the worship improvement process.

${ }^{1}$ George Barna, The Habits of Highly Effective Churches (Ventura, CA: Regal Books, 1999), 111. 
The Scriptures prophesied latter-day worship revitalization in Rev 14:6,7:

Then I saw another angel flying in midair, and he had the eternal gospel to proclaim to those who live on the earth - to every nation, tribe, language and people. He said in a loud voice, "Fear God and give him glory, because the hour of his judgment has come. Worship him who made the heavens, the earth, the sea and the springs of water."

Ellen G. White challenged the Seventh-day Adventist Church (SDA) to strive for this worship revitalization through the guidance of the Holy Spirit, and thereby increase member participation. She went on to suggest the following:

The prevailing monotony of the religious round of service in our churches needs to be disturbed. The leaven of activity needs to be introduced that our church members may work along new lines, and devise new methods. The Holy Spirit's power will move upon hearts when this dead, lifeless monotony is broken up, and many will begin to work in earnest who never before thought of being anything but idle spectators. ${ }^{1}$

Although the Holy Spirit grants spiritual gifts to His people to be used in revitalizing corporate worship, many small churches ${ }^{2}$ are handicapped by a member shortage. Compared to the larger churches, small churches suffer a hardship for which there is no simple solution. A lack of members who have the adequate skills and training, who practice their gifts, or who are willing to participate in the corporate worship experience significantly limits the possibilities for meaningful and creative worship in the small church. There is no simple answer to this problem.

Dennis Williams and Kenneth Gangel suggest some reasons why people are not more involved in church; for example: (1) some seem indifferent to their responsibilities;

${ }^{1}$ Ellen G. White, Testimonies to Ministers and Gospel Workers (Mountain View, CA: Pacific Press, 1923), 204.

${ }^{2}$ For the purpose of this dissertation "Small Churches" means a congregation with an average membership between 30-50; in any case less then 100 attending members. 
(2) some have never been challenged to become involved in God's work; (3) some lack confidence in their abilities; and (4) some misunderstand the task. ${ }^{1}$

Today's pastors must train and equip their church leaders in the ways of corporate worship and, as far as possible, allow them the freedom to develop ways to improve the corporate worship experience. Church leaders must in turn challenge the individual worshiper to see the importance of accepting the responsibility to serve God through participation in the corporate worship experience. When people in any congregation exercise worship improvement, for which God has given them gifts through the power of the Holy Spirit, miraculous things can happen.

\section{Purpose}

The overall purpose of this dissertation is to develop a model for improving the corporate worship service experience in the small SDA church. Many of the concepts presented are based on renewal discussions found in current worship literature and resources. Utilizing an APIE (assess, plan, implement, and evaluate) model, which will be further presented and discussed, church leaders can prayerfully assess, plan, implement, and evaluate their church's corporate worship experience. Most will become aware of a need for more extensive worship planning and increased variation in corporate worship expression. The ultimate goal of this project is to assist small churches in having more

'Dennis E. Williams and Kenneth O. Gangel, Volunteers for Today's Church (Grand Rapids, MI: Baker Books, 1993), 39-43. They also present some other reasons: Some feel it requires much more time and effort than they can contribute, some have been improperly catalogued, some are too busy, some must cope with dual-care households, and some make different choices in how they use their free time. 
profundity and variety, achieving more lay involvement, and improving the worshiper's ability to understand and communicate the Gospel message.

More specifically, chapters 2-4 of this dissertation contain resource materials to assist pastors in creating awareness in small-church leaders and helping them revitalize the quality of the corporate worship service through learning how to use the APIE model. Chapter 5 suggests an integration of the APIE model with traditional corporate worship elements. Chapter 6 presents a summary, conclusion, and some recommendations for further study. The appendix presents suggestions for church leaders in how to apply the APIE model in assessing, planning, implementing, and evaluating their present form of corporate worship.

\section{Justification}

God is the source and end of all true worship. He calls us to worship and to improve our lives. Corporate worship is one response to that divine call. It is imperative that Christians understand and worship God in spirit and truth (John 4:23). Randy T. Hodges believes that the most important activity in any church is worshiping God in His holiness. If the church does only one thing, it must worship. ${ }^{1}$

Leaders of small churches have been known to express frustration while trying to improve lives and to worship in spirit and truth. Someone was heard saying, "We're from a small congregation. When we go to camp meetings and see what different churches are

'Randy T. Hodges, $A$ Call to Worship (Kansas City, MO: Beacon Hill Press, 1996), 15. 
doing, we just get depressed because we don't have the resources-money and people-that many other churches have."

Almost every small church suffers feelings of inferiority when it compares itself to larger churches with more worship resources. Each has different gifts, and each a unique set of blessings and challenges. God does not call one church to be like another. God calls each church to do its best with the resources it has been given. This project encourages the small church to improve what it has rather than seeking to be something it is not. The information presented in this dissertation is designed to help the small church assess its current state of worship, explore new resources, create a plan for improving corporate worship, implement the plan, and then evaluate the effect of that plan on its quality of worship. No longer need the small church suffer feelings of inferiority when comparing itself to larger churches.

All churches, whether large or small, experience some form of corporate service, typically the main worship service that occurs each Sabbath. Currently, there exists little interaction between the components of the worship service (e.g., music, offering, preaching, and Scripture reading) and quality assurance, as reflected in a more vibrant corporate worship experience. Small church leaders face the challenge of transforming existing worship components into a more dynamic service, and increasing member involvement. Many small-church pastors and leaders are dissatisfied, and have expressed an interest in a corporate worship service improvement program.

Although there are few SDA writings addressing the corporate worship experience, there exists much non-SDA literature on this subject. However, few programs 
have actually been designed to put into practice an ongoing assessment of needs, coupled with redesigning and implementing solutions, in the small church's worship service.

There is a need to develop a model to revitalize worship in the small SDA church-one which integrates the existing small-church worship practices with current worship renewal practices. The model presented herein will be based on the need to "Assess, Plan, Implement, and Evaluate" (APIE) the corporate worship experience in order to revitalize the worship service.

\section{Limitations}

This study lays no claim to being exhaustive. Its focus will be to impart basic knowledge and provide tools that will enable church leaders to revitalize existing worship components by prayerfully incorporating some of the resources presented. In spite of the fact that some worship and quality assurance principles are discussed, this study does not offer a plan that fully explores all areas of worship and quality assurance. Although some principles are given, no attempt is made to provide a complete handbook on corporate worship. In like manner, this dissertation does not address the issue of corporate worship styles for the small church.

\section{Expectations}

This project will attempt to revitalize the corporate worship service in small, North American SDA churches, and will further attempt to provide a model for worship service revitalization that can and will be used in small SDA congregations in different cultural and geographical settings around the world. 
Leaders of small SDA churches may become better equipped to enrich their experience as worship leaders. Congregations may become better informed about the worship process through the use of the APIE model, thereby becoming more actively involved in the corporate worship process.

Finally, this project will help me acquire a deeper knowledge of quality assurance in corporate worship and will make me more effective as a pastoral worship leader.

\section{Definitions of Terms}

Several terms associated with the Seventh-day Adventist church and common to its leadership's vocabulary are utilized throughout this dissertation. Some of those terms are discussed in the immediate context in which they appear. However, to improve effective communication with the reader, a selection of the main terms is listed and defined below. For practical purposes, the terms will appear in alphabetical order.

APIE: A continuous improvement model to provide process skills to a small SDA church to Assess, Plan, Implement, and Evaluate its corporate worship service.

Church: A term that means not only a church building but includes any location where the members meet.

Continuous Improvement in Corporate Worship: Working together every week to make all things 1 percent better, rather than just one thing 100 percent better, in order to satisfy the needs of the worshiper and ultimately satisfy God.

Corporate worship: Worship that results from the joining together of Christians with like beliefs and ideas. 
Lay Leader or Church Leader: A person who does not hold a full-time paid position in the work of the local church.

$S D A$ : Seventh-day Adventist.

Worship-output: The delivery, the actions, and the results of worship created for a worshiper by the corporate worship process.

\section{Method}

In preparation for developing a model to improve the corporate worship service of the small SDA Church, this project will provide a survey of biblical principles for corporate worship as well as an analysis of current worship practices in the small SDA church. Furthermore, it will integrate ideas and suggestions from current literature on corporate worship and quality assurance in the presentation of the APIE model, and the discussion of the integration of this model with corporate worship elements. In addition, my fifteen years of pastoral work and experience in observing the need for corporate worship revitalization in small SDA churches will contribute an existential dimension to this study.

It is my belief that a model for corporate worship service improvement, designed to assist the leaders of small SDA churches to Assess, Plan, Implement, and Evaluate (APIE) the needs of their congregation within the corporate worship service, is imperative if the small North American church is to respond to its latter-day calling. Consequently, this project will emphasize the integration of the proposed APIE model with actual worship practices. 


\section{CHAPTER 2}

\section{THEOLOGICAL AND BIBLICAL PRINCIPLES OF CORPORATE WORSHIP}

\section{Theological Principles of Worship}

"O come, let us worship and bow down: let us kneel before the Lord our maker. For He is our God; and we are the people of his pasture, and the sheep of his hand" (Ps 95:6-7). What a magnificent invitation to worship! In a world that worships anything and anyone, here is a call to worship God, the Creator and Redeemer. Scripture insists that God is to be the recipient of human worship. "Worship God" is the command of Rev 19:10. "Exalt the Lord our God and worship at his holy mountain," is the call of Ps 99:9. The basic theological principle of worship is the attribution of supreme worth to God and to His Son, and they are the center and focus of worship. Worship begins with God and ends with the human response to the divine nature (Ps 27:8); it is to be emphasized that the human response itself is divinely inspired (John 6:44). Worship can rightly be offered only to God Himself (Matt 4:10). Worship is an end in itself considering that God is worthy of worship because of who He is.

The English word "worship" simply means "worth-ship." It is derived from the Anglo-Saxon weorthscipe-worth and ship, meaning the recognition of a person worthy of reverence and honor. When we worship, we are declaring that God is worthy. 
Etymologically, the word "worship" means the recognition and celebration of worth, value, goodness, and holiness. The Greek term most often indicating worship is proskuneo, meaning, literally, to kiss the hand toward one, or to prostrate oneself before another in reverence. ${ }^{2}$ John says, referring to God, "You are worthy, O Lord, to receive glory and honor and power" ( $\operatorname{Rev} 4: 11)$, and "Worthy is the Lamb who was slain" (Rev $5: 12)$.

When worshipers gather in corporate worship, every part of this spiritual experience needs to be directed toward God, and not toward any person or organization. God is to be honored, praised, adored, and obeyed. ${ }^{3}$ Only God is worthy of our worship. Warren Wiersbe affirms that "what people worship is a good indication of what is really valuable to them." To Wiersbe, the principle here presented is that "worship is the response of all that we are to all that God is and does. We don't worship God for what we get out of it, but because He is worthy of worship."

Worship celebrates the presence of God and the Lamb. All the worship actions in Rev 4 and 5 take place around the throne of God. Mankind is not called to glorify man,

'Joseph T. Shipley, Dictionary of Word Origins (New York, NY: Philosophical Library, 1945), s.v. "Worship."

${ }^{2}$ Franklin M. Segler, Christian Worship (Nashville, TN: Broadman \& Holman Publishers, 1996), 6.

${ }^{3}$ Robert A. Morey, Worship: It's Not Just Sunday Morning (Iowa Falls, IA: World Bible Publishers, 2001), 15-16.

${ }^{4}$ Warren W. Wiersbe, Real Worship, 2nd ed. (Grand Rapids, MI: Baker, 2000), 20.

${ }^{5}$ Ibid., 21. 
but to glorify God. Mankind is given worth not through self-exaltation, but by the voluntary death of Christ. Mankind's right place is on his/her knees before the throne of God, in the same way as the "elders fell down and worshiped" (Rev 5:14). Mankind is to glorify God (Ps 16:11) and to fear to be separated from His presence (Ps 51:11-12).

The cross and the resurrection of Christ are at the core of Christian worship, just as they are at the core of the church's preaching (see 1 Cor 15:1-8). The preaching of the gospel makes believers, who become worshipers. Christian worshipers will especially recognize the worthiness of God through His salvation act in Jesus. Paul wrote:

"Therefore God exalted him to the highest place and gave him the name that is above every name, that at the name of Jesus every knee should bow, in heaven and on earth and under the earth, and every tongue confess that Jesus Christ is Lord, to the glory of God the Father" (Phil 2:9-11 NIV).

The call to worship is this: "Repent therefore, and turn again, that your sins may be blotted out, that times of refreshing may come from the presence of the Lord" (Acts 3:19 RSV). The acceptance of this call is the key note for the celebration of the worthiness of the Lamb with singing and rejoicing. The worship in Rev 5 is dedicated to the praise of Christ as the victorious Lamb of God. Such worship is a recapitulation of salvation history and must find its parallel in the worship of God's people on earth. It is through a salvation-relationship with Jesus that man enters into worship with God. Because of His ministry, we are invited to come boldly into the presence of God. When we recognize the gifts of God, and see His great mercy and how He loves to have us spend time in contemplation of His love for us, we will worship Him in spirit and in truth. 
Worship is offering. Throughout the Old Testament, to worship was to present an offering that was always symbolic of the offering of oneself (Ps 96:8). Sacrifice was regarded as the totality of worship. Likewise, the priesthood of the New Testament was established to the same end-to offer up spiritual sacrifices (1 Pet 2:5). We go to church primarily to give, and secondarily to receive.

The true offering to God is righteousness of heart and life. Moreover, worship involves the whole individual. In includes seeking for "clean hands" and "a pure heart" (Ps 24:3-4). It also embraces obedience and service (Luke 6:46). The true worshiper not only seeks to be in His presence, but also to look forward to follow His purpose (see Exod $3: 2,10 ;$ Isa $6: 1,8)$. True worship motivates us to go about doing good, identical to what our Lord did.

Let us remember that authentic worship will be worship that is primarily directed to God. Not only will words and thoughts in worship be directed to God, but they will be of, or about, God. Because God is the object of worship, any reference to the individual will be incidental (Rev 5:9). If we are setting out to worship God, we will not be putting ourselves at the center. A prayer of request to God that asks for something from Him, is not really praise and worship to God-not in the real sense of the word. Genuine worship occurs when we recognize the greatness and power of God, and we bow in awe and reverence. However, when we do that, it is not a very big step to the place where we recognize our need of Him, and call on Him. That is what we must do. That is what He is asking of us. Genuine worship means that when we recognize our need, we concentrate on Him, and His ability and desire to help us, rather than on all our sorrows or wishes. 
The biblical theology of worship leads us into four specific actions in worship: adoration, celebration, devotion, and renewal.

Through adoration in worship we affirm the goodness of God (1 Sam 12:7; Ps 103:1-6); we recognize His worthiness (Rev 5:9, 12-13); we gain a sense of awe and wonder (Deut 4:39; Ps 8:1, 3-4); we acknowledge His sovereignty (1 Chr 16:25; Ps 45:6); and we adore Him with reverence (Heb 12:28).

With celebration in worship we give praise and thanksgiving (1 Chr 16:8-10; Ps 100:1-3); we bring gifts to God (1 Chr 16:29; Mal 3:10; 2 Cor 9:7); we testify about Him (Mal 3:16; $2 \operatorname{Tim} 1: 8$ ); we proclaim His Word (Rom 1:16; $2 \operatorname{Tim} 4: 2 ; 3: 16-17)$; we develop community and participation (Col 3:16; Heb 10:25); we worship with spontaneity in expression (Ps 47:1,6); and we rejoice in the cross of Christ (Gal 6:14).

Through devotion in worship we seek for meditation and reflection in our Redeemer (Ps 1:1-3; 19:14); we look for prayer and intercession (Jer 29:12-13; Pss 51:10; 139:23-24); we desire repentance (Ps 51:1-3; Isa 40:1-2; Acts 2:38); and we receive the presence of the Spirit and His gifts (John 16:13; Rom 8:14-16; 1 Cor 12:1, 4; Eph 4:1113).

Seeking for renewal in worship, we experience wholeness (Ps 23:1; Mic 6:8; 1 Thess 5:23); we experience peace and rest (Jer 17:7-8; Heb 4:9); we experience a sense of destiny (Isa 40:31; Heb 11:10); we receive restoration to God's image (Ps 23:3; Jude 24, 25); and we glorify God in life and service (Matt 28:19-20; Eph 3:17-21).

God must be seen as the initiator, the prime mover in the drama of salvation, and because God is love, He is the object of our adoration (John 3:16; Rom 5:6-8; 1 John 3:1; 
4:7-8). The cross stands for the savings acts of God in Christ (Gal 6:14; Eph 2:11-18;

Phil 2:5-11). Although to the ancients it was a symbol of torture and degradation, to the Christian it is cause for jubilant celebration and an inexhaustible theme for preaching and praise. The cross leads us into the experience of repentance (Job 42:6; Isa 6; Acts 2:18; Rom 2:4). Here the gospel impacts the individual, bringing reorientation at the deepest and most personal level. Consequently, repentance will guide us to experience wholeness (Rom 5:1-5; 8; Col 1:21-28). Whole in status and achieving wholeness in state, the Christian finds in worship many opportunities to rejoice in assurance and to grow in grace.

\section{Biblical Principles of Corporate Worship}

Occasions of corporate worship are recorded throughout the Bible. This biblical overview of corporate worship will provide valuable examples of principles and practical worship applications for leaders in the small church today.

Much can be learned from examining corporate worship as presented in both the Old and New Testaments. The apostle Paul pointed back to the Old Testament when he instructed us, "For everything that was written in the past was written to teach us, so that through endurance and the encouragement of the Scriptures we might have hope" (Rom 15:4). We, too, must look back, learn from our predecessors, and carry these truths into our modern-day churches. Contemporary church leaders must be encouraged to study these biblical examples and use them to better meet the needs of today's church.

This chapter will identify some of these biblical corporate worship principles, explore how biblical worship was established, and examine how the principles can be 
applied to the contemporary worship experience. Since Christians believe the Word of God to be the ultimate authority, these principles gain credibility when gleaned from the Bible, and, as such, there exists no finer "self-help" manual for the present-day church lay leader.

The Bible tells us that corporate worship is one of God's instruments used to fulfill the intellectual and spiritual needs of His people. Some of the scriptural references, found herein, will not only provide corporate worship references, but will help us better understand the kind of worshiper God is seeking. Jesus said: "Yet a time is coming and has now come when the true worshipers will worship the Father in spirit and in truth, for they are the kind of worshipers the Father seeks" (John 4:23 NIV).

The biblical worship experience emphasizes first of all a personal relationship with God and, second, service to Him through corporate worship. The Lord demonstrated this principle when He told Martha that, by sitting at His feet, Mary had chosen what was better (Luke 10:38-42). In the same way, it is important that a person first experience worship with the Lord personally before worshiping Him in a corporate way. Worship should be a progressive experience. Worship begins privately, then becomes corporate, and then improves through quality assurance in choosing how best to worship God. It should be the lay church leader's goal to encourage congregants to adopt a "Mary" attitude, thereby improving the quality both of their private and corporate worship experience.

As we further explore biblical principles of worship, a progressive pattern emerges illustrating the benefits of a deeper worship experience: (1) God is looking for worshipers 
(Luke 19:40); (2) He desires to manifest Himself to them and through them (2 Chr 16:9;

Ps 95:6; John 4:23-24); as we manifest Him, (3) we minister to the Lord (Ezek 44:15-16;

1 Pet 2:9); (4) as we worship, we draw near to God and He draws near to us (Heb 10:19-

25 ; Jas 4:8); and consequently, (5) we respond to His presence (Luke 19:35-40).

Since the beginning God has intended for us to have a personal relationship with Him and then extend this experience to the corporate level where we share our experience with others. God relates to His people as individuals and as a group. He is willing to communicate with them and have a dynamic experience now and forever. Vernon Whaley further illustrates this principle when he comments as follows:

The Bible chronicles God's plan to bring humanity to himself so that together they may enjoy a dynamic relationship through communication, obedience, service, ministry, humility, and prayer. When he provided the Old and New Testaments, he revealed his plan for redemption and in the process provided a snapshot of how we will worship in eternity.'

Throughout the Bible the concept of worship is first personal, and then is demonstrated in a corporate way. God seeks human beings in a personal way with the ultimate purpose that they will worship Him for eternity. Corporate worship demonstrates the willingness of God's people to one day be for eternity worshiping the Creator and Savior Jesus Christ.

So far we have recognized the personal and corporate components of biblical worship. Now we will examine the situations in which corporate worship occurred. The Old and New Testaments not only show the personal aspect of worship but

'Vernon M. Whaley, The Dynamics of Corporate Worship, ed. Warren W. Wiersbe, Ministry Dynamics for a New Century (Grand Rapids, MI: Baker Books, 2001), 53. 
also present worship as a community revealed in a public worship experience that can be seen in different situations. Each situation was for the purpose of making the participants more God-conscious. The elements of the worship service existed so that God's people might be reminded of Him and draw closer to Him. These Stages of Worship ${ }^{1}$ are introduced in the first book of the Bible when "men began to call on the name of the Lord" (Gen 4:26), and can be outlined as follows:

1. Altars are used to honor God (Gen 8:20). Through the Altar, a person could bring offerings in response to His divine nature. Worship is an offering. The objective was primarily to give and secondarily to receive. In worship we are to think of God first and of ourselves only in relation to God and His attributes. The aspect of bringing ourselves as a living offering to the Altar can help in the revitalization process of actual worship.

2. The Tabernacle and Ark of the Covenant were built to receive God's presence (Exod 25:8-9). God's house was a place of revelation and response- a place where a person could respond to the mystery, the majesty, and the mercy of God. The sense of God's presence has been lost and needs to be given more attention. The worship service needs to provide time to listen to His voice and to respond to His voice calling the church to worship and serve Him.

3. The Temple stands as a "permanent" house for the Ark (2 Chr 2:1), demonstrating the need to be permanently in God's presence. Worshipers would come to

'See Patrick Kavanaugh, Worship: A Way of Life (Grand Rapids, MI: Chosen Books, 2001), 66. 
His house in the spirit of eager anticipation of His presence. In order to experience the essential nature of worship, the worshiper needs to demonstrate a spirit of expectancy of been permanently in His presence. Temple worship was a symbolic ritual with mainly sacrificial emphasis that was to find its culmination in Jesus Christ's sacrifice of Himself. The temple suggests the concept of a special space set apart to worship. It cannot be common. The place is to be permanent with a special purpose-to worship.

4. A synagogue offers a gathering place for worshipers (Luke 4:16). As a symbol of the assembly of God's people, it shows worship to be essentially a corporate experience. Worship begins privately and is celebrated corporately. It celebrates salvation in Christ who came. Going to church helps to create an idea of God's family which one day will be together forever.

5. Christian church services were held in the remains of the Temple (Acts 5:12), then in homes (Rom 16:5), and later in church buildings. The latter would not happen until long after the New Testament was written. The early believers had a new hope in the return of Christ. All worship activities were geared toward family, community, and oneness, with the desire to live in God's presence for eternity.

The biblical experience of corporate worship provides the worshiper with an opportunity to seek God's presence, to draw closer to Him, and to honor the Lord. These events demonstrate that it is God's intention for each one of us to have a personal relationship with Him and, then, to share this experience with others. He desires through corporate worship to recover the idea of the church as a family under His protection as a Father. 
Old Testament symbols of worship pointed to Jesus, and, in the New Testament, the cross pointed to Jesus as the center of our worship. We worship God through Jesus. Each component, symbol, and element of worship has the unique purpose of drawing us to the sacrificial Jesus worthy of our worship. Congregating in corporate worship is not sufficient; the gathering must happen around Jesus focusing on the physical elements of the cross, table, communion, and church, which demonstrate corporately our salvation experience.

Through worship in the Bible we see God seeking His people and ultimately inviting His children to worship Him for all eternity and abide in His house forever. It is His intention to be close to us and have this closeness shared with others in corporate worship of His holiness. Corporate worship demonstrates that God's people are willing to accept His invitation to worship Him for eternity because He is worthy to receive glory, honor, and power $(\operatorname{Rev} 4: 11)$.

Although the contemporary church does not function exactly as described in the Bible, it should keep the biblical principles alive in all corporate worship activities. The worship service should provide the worshiper with an opportunity to honor the Lord, to draw closer to Him, and, ultimately, to seek to be in His presence. In some churches, worship of the Creator has turned somewhat to worship of the symbols, the furniture, and the elements. Church leaders are charged with the responsibility of providing a special environment in which believers can freely come, worship, and strive for the experience of an encounter with God as presented in the Bible.

The Bible is the ultimate source of faith; its principles, when put into practice, will 
help the church revitalize its corporate worship experience. Paul Basden points out:

For Christians, the ultimate rule of faith is the Bible. This means that we must turn to holy Scripture for our primary source of knowledge about worship. The biblical story shows us that worship is fundamentally a response of an individual or a people to a mighty act of God. The pattern that emerges in the Scriptures looks like this: God powerfully acts on behalf of God's people, the people respond in gratitude and praise, and God accepts their act of worship. This pattern, consistent throughout the Bible, points out a central truth: in worship, God always initiates. Worship is a human response to the divine initiative. You can see the pattern in both the Old Testament and the New Testament.'

It is important to consider some important aspects of corporate worship in the Old and New Testaments, and God's experience with people in those days, as well as Jesus' example and the influence of the Holy Spirit in the early Christian church.

\section{Corporate Worship in the Old Testament}

The Old Testament provides the foundation for most corporate worship principles. It is here that we are presented with the first insights into what God expects of His people through corporate worship and are shown time and again that God always provides for His people. God uses the corporate worship experience to teach His people, who are then called upon to communicate His goodness and mercy to the rest of the human race.

Some elements of the worship experience in the Bible are still part of a personal and corporate experience today. At least five general elements of corporate worship are present in the Old Testament: (1) thanksgiving-His people's gratitude for God's miraculous protection at the Red Sea (Exod 15:1-21); (2) praise for victory-when terrible, unexpected news comes (e.g., warfare), God's people immediately arise, seek His solution

\footnotetext{
'Paul Basden, The Worship Maze: Finding a Style to Fit Your Church (Downers Grove, IL: InterVarsity Press, 1999), 19.
} 
to the problem, and give Him praise (2 Chr 20:21-22); (3) feasts, demonstrating the need to be regular and not sporadic in the worship of the Lord (Lev 23:24-27; Deut 16:16); (4) celebration, bringing the idea of freedom to worship the Lord "with all our might," knowing that God joyfully accepts such an offering of exuberant praise (2 Sam 6:12-23; 1 Chr 15-16); and (5) dedication, suggesting the necessity of dedication when beginning something new (2 Chr 5:1-7:10; 29:3-36; Ezra 3:11-13; Neh 12:27-43). ${ }^{1}$ These components of corporate elements in worship provide a platform that presents elements of worship for our own experience. God is looking for a kind of intimacy in worship that these components of worship as thanksgiving, praise for victory, feasts, celebration, and dedication can be present in our lives and part of the actual church worship experience.

Some aspects of corporate worship in the Old Testament, such as buildings, leadership, and a consecrated place, are still present in today's church. However, some aspects of worship were lost, while others became confirmed. The following discussion will focus on two corporate experiences as they relate to the contemporary church service needs: the Temple and synagogue worship services and the way they influence the current church service.

\section{The Temple}

We draw two lessons from corporate worship at the Temple: God's autonomy and the worship of His people. The Temple worship service was the center of Israel's worship. It was the place, set aside by God, for human beings to come and partake of the

${ }^{1}$ Kavanaugh, 68-73. 
corporate worship experience. Temple worship was a highly symbolic ritual that was based on the principle of a common recognition of God's autonomy. Its main emphasis was sacrifice, an emphasis that was to find its culmination in the shedding of Christ's blood on the cross-the ultimate sacrifice. Our worship should be Christ-centered.

Corporate worship was presented with form, sequence, and organization, with the touch of human involvement. Many priests were involved in the Temple activities. In daily services after the offering of incense, an unblemished lamb was sacrificed and formal prayers were recited, including a recitation of the Shema, the Jewish profession of faith (Deut 6:4-9). The service then closed as it had begun with the offering of incense. The same order of worship was observed in the worship services.

The personal spiritual experience was demonstrated through the singing in corporate worship at the Temple. In examining the components of Temple worship, we find that, on certain occasions, the psalms served an important role as they were chanted and sung. These holy songs provided a public opportunity to praise God for His attributes (Ps 147), creative acts (Ps 8; 19:1), and rulership of the nations (Ps 67:4). Psalms also provided opportunity for an intimate spiritual experience (Pss 34:1-10; 40:1-3), thanksgiving (Pss 103, 105), prayers of deliverance (Ps 142), confession of sin (Ps 51), and lament and anger (Pss 38;42), as they were chanted by the people of Israel on many occasions.

Corporate worship experience at the Temple demonstrates that God is willing to occupy a constant presence among His people. Consequently, the Temple becomes a 
place for prayer, instruction, and the revelation of God's Word. ${ }^{1}$

The contributions of the traditional Temple service to contemporary corporate worship are extensive. Small SDA churches today still use many of its basic concepts. From the Temple are borrowed such terms as sacrifice, lamb, repentance, forgiveness, high priest, and the partaking of bread and wine during the communion service. ${ }^{2}$

Foundational concepts— such as giving praise to the Lord, coming before Him with prayer and thanksgiving, and seeking His forgiveness for our sins, to identify a few-are all essential parts of the contemporary worship experience, illustrating that God is the same yesterday, today, and tomorrow.

The Synagogue

As we examine worship at the synagogue, we become aware of the growing involvement of the congregation during the service.

Ezra the priest was instructed to read the Book of the Law of Moses before the assembly. During this gathering the Lord was blessed, the people lifted their hands proclaiming "Amen," and they bowed their heads and worshiped with their faces to the ground. With the return from exile, the Temple now destroyed, this reference to worship may indeed be one of the first prototypes of the synagogue service. Even though New

'See Whaley, 57.

${ }^{2}$ Bread and wine appear for the first time as ritual symbols in the narrative of Melchizedek, as a ritual symbol of the partaking of bread and wine (Gen 14:18). The symbolism is then further carried out in the sacrifices of meat and wine of the Temple, and finally becomes bread and wine (both in the synagogue and the church) after the destruction of the second Temple. 
Testament references are more abundant, we are left with little doubt that synagogue worship found its roots in Old Testament times.

Synagogue leadership was entrusted to the elders, who in turn selected the ruler of the synagogue from among themselves. This ruler was responsible for conducting synagogue worship services and often delegated the various tasks to others. Lay persons were the active agents of the corporate worship service. Here we find the pattern for our pastors and lay church leaders who are the active agents for today's corporate worship.

On Sabbath, as part of the traditional synagogue service, at least seven persons took turns reading the Scriptures. Indeed, one distinctive aspect of corporate worship, found in the synagogue and carried over into contemporary Christian worship, was the emphasis given to the reading and exposition of Scripture and to prayer, which where done through chanting and singing. We find the recitation of the Decalogue and the Shema, and the singing of Psalms. ${ }^{1}$

Andrew Hill points out that central to synagogue worship were issues of faith, justice, and mercy, as taught from the Torah. This worship design follows, in part, the Sabbath Temple experience. It served as a basis for synagogue teaching and has become central to our modern-day worship service. ${ }^{2}$

'For a discussion of the continuity of the worship practices between the Temple and the synagogue see C. W. Dugmore, The Influence of the Synagogue Upon the Divine Office (Westminster: Faith Press, 1964); Martha Zimmerman, Celebrate the Feasts of the Old Testament in Your Own Home Church (Minneapolis, MN: Bethany House Publishers, 1981); and Ralph P. Martin, Worship in the Early Church (Grand Rapids, MI: Eerdmans Publishing, 1992). 1993), 231.

${ }^{2}$ Andrew E. Hill, Enter His Courts with Praise (Grand Rapids, MI: Baker Books, 
If the actual church received the basic concepts of worship from the Temple, the synagogue set the general pattern for the modern worship service elements. The worship service of the small SDA church, like the synagogue, includes Scripture reading, exposition of the Word, prayer, and some acts of worship such as standing for prayer, reading responsively, and responding (as with "Amens").

\section{Corporate Worship in the New Testament}

An investigation of New Testament worship will enrich our study with still more information about principles of worship. The lesson we learn from New Testament worship will furnish us with principles of worship, forms and expressions of worship, and the spirit of worship.

New Testament examples of worship are found in the Gospels and the books of Acts and Revelation. For instance, the first scene of corporate worship appears in the Gospel story of the angels singing "Gloria in excelsis deo" as an announcement of Jesus' birth (Luke 2:8-14). The apostles and church leaders, instead of God directly, provide now the primary source of information to God's people.' A few other examples, such as the disciples singing a hymn before going to the Mount of Olives after the Last Supper (Mark 14:26), and the post-crucifixion worship described in Acts, are scattered throughout the New Testament. The final scene of corporate worship appears in heaven as described by John in the book of Revelation. We will use Patrick Kavanaugh's categories to present these principles.

'Eugene B. Habecker, Leading with a Follower's Heart (Wheaton, IL: Victor Books, 1990), 174. 
According to Kavanaugh, New Testament descriptions of worship events reveal six principles of worship:

1. Worship toward Jesus: Whoever does not honor the Son does not honor the Father who sent Him (John 5:22-23). There is a need to worship Jesus as He truly is the Savior of the world and the only way to God (Col 1:16-18). He was worshiped openly by groups of believers (see Matt 2:11; 14:33; 21:9; Mark 11:1-11; Luke 19:28-40; John $12: 12-15)$

2. Worship of the risen Christ: The actions surrounding resurrection mean victory (see Matt 28:9; Luke 24:52).

3. Worship associated with the Holy Spirit: Scenes of corporate worship after receiving the power of the Holy Spirit (see Acts 1:8-14; 2:1; 4:31; 10:44-46; John 14:26; $16: 13)$.

4. The disciples' praise: A lifestyle of praise is indicative of continual daily worship experience (see Luke 24:53; Acts 2:46-47; Rom 10:4; Col 2:16-17).

5. Worship as a witness: The best form of service is to witness with joy and confident praise when in crisis (see Acts 16:25).

6. Heavenly worship: Corporate worship in the New Testament both begins and ends in the heavens (see Luke 2:13-14; Rev 4:1-11; 5:6-14; 7:9-12; 11:15-19; 14:1-3; $15: 2-5 ; 19: 1-7) .^{\prime}$

As for the forms and expressions of worship, Vernon Whaley suggests that at least nine such expressions can be found in the New Testament and be applied to the church life

'Kavanaugh, 75-82. 
experience today: (1) spontaneous expressions of praise, (2) preaching, (3) Scripture reading, (4) singing and making melody, (5) confessions of faith, (6) fellowship, (7) prayer, (8) breaking of bread, and (9) communion. ${ }^{2}$

These New Testament forms of worship are characterized by a spirit of worship that can be summarized into the following categories:

1. Spontaneity and vitality. While in the Old Testament Temple and synagogue worship the expression of worship was more formal, corporate worship among the New Testament Christians was characterized by irrepressible vitality and spontaneity. It is possible that this rejoicing attitude was carried over from the Israelites' way of celebrating the various festival.

2. Simplicity. Corporate worship in the New Testament seems to value simplicity. It is expected that coming from a Jewish-Christian background the worship service was compounded of some of the main elements of synagogue worship, such as the responsive reading, Scripture exposition, and the recitation of prayers.

3. Flexibility. Paul's writings to the Gentile Christian church at Corinth exemplify the unity in diversity to be modeled by church leaders. Flexibility in the worship service and courage to experience new elements are qualities existing churches need to improve in order to respond to the needs of different communities and people.

4. Organization. The freedom given of the worshipers involved in corporate

\footnotetext{
'The introduction of hymns as a new element in New Testament worship service can be seen in several New Testament passages, e.g., Eph 5:19; Col 3:16; see also some hymn fragments in Eph 3:21; 1 Tim 3:16; 2 Tim 2:11-13; Rev 4:8 and 5:9.

${ }^{2}$ Whaley, 60 .
} 
worship may wrongly be associated with lack of organization. However, absence of formality does not necessarily mean that the worship services were conducted without a decided pattern or that they were at the mercy of the mood or desire of the people. In corporate worship, spontaneity and freedom, when rightly understood, do not imply disorder, lack of improvement or excellence, or a worship service detached from traditional forms and elements. While the New Testament church recognized the value of freedom, enthusiastic expression, and spontaneity in corporate worship, it was not without consideration of the fact that this freedom brought with it an element of limitation and a constant interest in corporate worship revitalization (1 Cor 14).

None of the ways in which we express our worship, however, can achieve something without the empowerment of the Holy Spirit.

\section{Empowerment Through the Holy Spirit}

Whaley points out that "public and private worship in the New Testament reflect the realization that God's spirit dwells in the hearts of people."

It seems evident that in the worship experience of the New Testament church, the Holy Spirit was manifest in great power (Acts 1:8), affecting every element of worship-the singing, praying, preaching, witnessing, and offering-and making the apostolic church worship very intense and vibrant. Ellen $\mathrm{G}$. White comments that "if all were willing, all would be filled with the Spirit.... The Lord is more willing to give the

'Ibid., 59. 
Holy Spirit to those who serve Him than parents are to give good gifts to their children."1 It is hard to cultivate the spirit of the New Testament church without the presence of the Holy Spirit. It seems that all were happy with the gifts received from the Father. Within them dwelt a surge of emotion, and most astounding things happened to them; a deep thankfulness and irrepressible joy possessed them, and their praises were simple, spontaneous, and exuberant.

Corporate worship in the New Testament was primarily of the spirit, that is, conducted in such a way that the fingerprint of the Holy Spirit could be seen in every simple and familiar expression of the worship service. At the beginning of his first letter, Peter assigns a tribute of praise and thanksgiving to God for His mercy and living hope through Jesus Christ (1 Pet 1:3). Ellen White says that it is because of the wonders of the Holy Spirit in the church that Paul expresses his joy over their conversions and growth in grace and he gives God all the praise for the transformation of heart and life. ${ }^{2}$

Empowered by the Holy Spirit, these new believers now become actively involved in the worship service of the New Testament church. Paul declares: "This is what I mean, my brothers. When you meet for worship, one person has a hymn, another a teaching, another a revelation from God, another a message in strange tongues, and still another the explanation of what is said. Everything must be of help to the church" (1 Cor 14:26 TEV).

${ }^{1}$ Ellen G. White, The Acts of the Apostles (Mountain View, CA: Pacific Press, 1911), 50.

${ }^{2}$ Ibid., 325. 
Corporate worship when led by the Holy Spirit will always seek to maintain harmony within the church through the revelation of Jesus Christ as contained in the Bible. Paul offers inspired advice, saying that "the gift of proclaiming God's message should be under the speaker's control, because God does not want us to be in disorder but in harmony and peace" (1 Cor 14:32-33 TEV).

Paul was also seeking improvement and quality assurance in the corporate worship of the New Testament church. In his letter to the church of Corinth (1 Cor 14), Paul tries to correct some abuse in the worship service of the Corinthian church when he sets forth principles to guide the local church: (1) All these things must be done for the strengthening of the church (vs. 26), (2) God is not a God of disorder but of peace (vs. 33), and (3) everything should be done in a fitting and orderly way (vs. 40).

\section{Jesus' Example}

Any study of a Christian activity, including worship, would be incomplete without an examination of Christ's experience. His experience provides an additional interactive leadership model that demonstrates that $\mathrm{He}$ is not only our Lord and Savior, but our example, mentor, and teacher. From the beginning of His ministry He was already leading through example and forming leaders through instruction.

Jesus faithfully participated in the corporate worship of God as practiced in His day. Luke tells us of Jesus' public worship habit: "So He came to Nazareth, where He had been brought up. And as His custom was, He went into the synagogue on the Sabbath day, and stood up to read" (Luke 4:16 NKJV). Everyone who claims to be a 
follower of Jesus Christ should worship God. As Jesus customarily worshiped corporately with God's people, so we should follow His example. Ellen G. White comments that "happy is the family who can go to the place of worship on the Sabbath as Jesus and His disciples went to the synagogue."1

Communion with the risen Christ, with the breaking of bread (1 Cor 11:1-34), was another form of corporate worship in the New Testament between Jesus and His disciples. After Jesus ascended to heaven, His followers met with the firm conviction of the continuing real and intimate presence of their living Lord. As a small church in those days, they trusted in what Jesus had promised: "Where two or three come together in my name, there am I with them" (Matt 18:20 NIV). In the same way, we need the corporate worship experience to recapture this intimate presence of Christ.

One of the venues for corporate worship in the time of the early Christians in the New Testament was private homes (Rom 16:5; 1 Cor 16:19; Col 4:15; Phlm 2), validating the assurance that Jesus can be present in any size of congregation, and demonstrating, in a peculiar way, a sense of togetherness and intimacy in the presence of Jesus Christ.

Under the influence of the Holy Spirit, with the example of Jesus and the Word of God, and out of this experience of intimacy with the real presence of Christ, the early church in the New Testament was inspired to serve the Lord and one another. They were following the biblical principle stating that "you shall worship the Lord your God, and Him only you shall serve" (Matt 4:10). Warren Wiersbe points out that "worship and service 140.

'Ellen G. White, My Life Today (Washington, DC: Review and Herald, 1952), 
go together, in fact, it is difficult to conceive of worship apart from service. . . . Service is worship if we're serving the Lord and giving Him our best."'

Christ-centered worship became the major priority for the new believers, and service through worship became their mission. According to Robert Webber, "when Christ is the center of worship, all of the goals for worship are achieved: Christ-centered worship educates, evangelizes, heals, develops spirituality-and is most enjoyable."2

The New Testament church was focused on worship. As Sally Morgenthaler points out, "worship was the main attraction." The Bible says that the apostles and new believers devoted themselves to the teachings, fellowship, breaking of bread, and prayer. Every day they. met in the Temple to praise God and "enjoy the favor of all people." As a result, the Lord "added to their number daily those who were being saved" (Acts 2:4247). As Robert Webber puts it so well, "in both the Old and New Testaments, God's purpose in revealing himself, in redeeming, and in bringing a people into existence was to create a worshiping community to be a sign of his redeeming work." ${ }^{.4}$

'Wiersbe, 70 .

${ }^{2}$ Robert Webber, The Worship Phenomenon (Nashville, TN: Abbot Martyn, 1994), 33.

${ }^{3}$ Sally Morgenthaler, Worship Evangelism: Inviting Unbelievers into the Presence of God (Grand Rapids, MI: Zondervan Publishing House, 1995), 39.

${ }^{4}$ Robert Webber, Worship Is a Verb : Eight Principles for Transforming Worship, 2nd ed. (Peabody, MA: Hendrickson Publishers, 1992), 29. 


\section{An SDA Theology of Worship}

The theological idea of the everlasting gospel (Rev 14) is central to the SDA mission, and as such should be reflected in both worship theology and experience.

God's last message begins with a call to His followers to worship Him as a united people (see Rev 14:7). Consequently, SDA worship has the responsibility "to proclaim" (Rev 14:6) in its worship the Word of God, the eternal gospel, which contains the three themes of the Sabbath, the heavenly ministry of Christ, and His second coming:

Then I saw another angel flying in midair, and he had the eternal gospel to proclaim to those who live in the earth - to every nation, tribe, language and people. He said in loud voice, "Fear God and give him glory, because the hour of his judgment has come. Worship him who made the heavens, the earth, the sea and the springs of water." (Rev 14:6-7 NIV)

It is not possible for SDA members to think about worship, or to participate in worship, without reference to the Sabbath and its meaning. The Sabbath points to Creation and redemption and is a reminder that time is to be used to the glory of God and the edification and well-being of mankind. The celebration of these two emphases are central to worship for the SDA church.

Defining the day of rest for the SDA church, the Sabbath provides many deep insights into worship, gathered around themes such as creation, remembrance, and rest. In SDA worship God is adored as Creator (Pss 8 and 19), and the very cycles of time bring an anniversary-type remembrance. Ultimately, Sabbath brings rest and security (Gen 2:13; Isa 58; Heb 4), a rest that comes with success and completeness, with security from evil, and even with the assurance of justice.

Yet, for the SDA church, worship is not only remembering God's past acts, but 
also focusing on the present activity of our Lord in the heavenly sanctuary: Christ who has died for us and now lives for us, making intercession before the throne of God (Heb 12:12). As the objective of our devotion in worship stands in human flesh and priestly robe, carrying our concerns and needs into the Father's presence, we need to worship with musical and liturgical symbols and actions that help us to connect with the transcendent events and actions going on at the present time in heaven.

The focus of Adventist worship is not only on the past events of history, or on the present events in the sanctuary above that will determine history, but also on the fulfillment of God's Word in future historical events. As Paul wrote: "Our citizenship is in heaven. And we eagerly await a Savior from there, the Lord Jesus Christ, who, by the power that enables him to bring everything under his control, will transform our lowly bodies so that they will be like his glorious body" (Phil 3:20-21 NIV). That hope rests firmly on the Biblical promises concerning the imminent return of Christ. Adventist worship takes place in the assurance of His coming (Matt 24; 1 Cor 15; 1 Thess 4; Heb 9:29). The prospects of complete renewal of the person (body, mind, and spirit) and the renewal of nature itself, are connected, in the Adventist worshiper's mind, to the second advent. It is in anticipation of that day that the church of the present time worships.

Finally, Adventist worship is more than a collection of congregations around the world, all confessing Jesus as Lord. It is the gathering together, under His lordship, of those who are bound together in a unity of belief, set apart and identified as His body by their faith in Christ and their obedience to His commandments (Rev 14:12). What we say and do when we worship is a corporate act that defines and illustrates the biblical truth for 
the endtimes, and the final gathering with Jesus at His second coming.

The Adventist perspective and understanding of worship indicate that in preparation for the return of Christ there is to be a new and united institution, that a new name has been given under which we are to assemble as the people of God, that in the last days the historic message of salvation in Christ is rooted in the Sabbath, His heavenly ministry, and His coming again, and that the celebration of His expectant church is to be reflective of these elements (see Rev 14:12). Certainly, the content of our worship actions needs to be faithful, strong, and biblically sound, until the time He appears for His gathered people. If, as we believe, the SDA church is the true movement calling God's people to a unity based on the Scriptures, then its worship ought to reflect that conviction.

\section{Biblical Expressions of Worship}

The Bible contains many expressions of worship which can be applied to and experienced by the church today. These elements of worship are valid for private or corporate worship. The following list of biblical expressions of worship is not intended to be exhaustive in any way, and other expressions can be found and added to these.

The biblical expressions of worship are presented as follows:

1. Singing to God (2 Chr 29:27; Ps 149:1-2; Col 3:16).

2. Singing a new song (Pss 96:1-2; 144:9; Isa 42:10).

3. Singing or speaking with your spirit (1 Cor 14:14-17).

4. Speaking about God (Ps 145:6-12).

5. Playing musical instruments ( 2 Chr 5:11-14; 29:25-30; Pss $144: 9 ; 149: 3 ; 150)$. 
6. Shouting with joy unto the Lord (Ezra 3:10-11; Pss 47:1; 66:1).

7. Clapping hands. This is the "Father's heartbeat." Release of joy and thanksgiving. Also a powerful tool against the enemy's strongholds, many times combined with shouting, praise and singing (Pss 47:1; 98:8).

8. Dancing. This celebration of God's victory is a full expression of joy, rejoicing, and intimacy with the Lord (Exod 15:20; 2 Sam 6:14-16; 1 Chr 15:29; Pss 149:3; 150:4).

9. Celebrating God with banners (Pss 20:5; 60:4; Cant 2:4; Isa 13:2).

10. Weeping is a response of intimacy, joy, and awe in God's presence (Ezra 3:12$13)$.

11. Lifting up of hands symbolizes praise, prayer, and meditation, an outward expression of our hearts that shows dependence, gratitude, and surrender (Neh 8:6; Pss $28: 2 ; 63: 4 ; 119: 48 ; 134: 2)$.

12. Bowing in repentance and worship. Bowing with faces to the ground demonstrated reverence and respect (Neh 8:6; Pś 95:6-7).

13. Kneeling. Kneeling, literally meaning "to bless" God, shows humility, meekness, and submission (Ps 95:6).

14. Lying prostate. Having one's face in the dust demonstrates total awe, reverence, humility, and adoration ( $\operatorname{Rev} 1: 10-17)$.

15. Standing in His presence in acknowledgment of reverence and service to royalty (Deut 10:8).

16. Meditating and pondering the attributes of God in our hearts (Ps 77:12; Phil $4: 8)$. 
17. Giving of the first fruits as an offering (Prov 3:9).

18. Reading, learning, teaching, and memorizing God's Word (Ps 119).

\section{Summary}

The Scriptures certainly are the best starting place for the study of Christian corporate worship. The Temple, the synagogue, the disciples, Jesus, and the empowerment of the Holy Spirit are perfect examples of basic principles for corporate worship in the Bible. The Bible leaders wrote, exemplified, and provided principles of worship that are needed in the SDA small church. The biblical principles reveal necessary qualities for an effective revitalization in corporate worship. Corporate worship experience in the Bible demonstrates that God, through His autonomy and the worship of His people, is willing to occupy an everlasting presence among His people, providing a place for prayer, instruction, and the revelation of God's Word. Likewise, under the influence of the Holy Spirit, through the example of Jesus and the Word of God, and out of this experience of intimacy with the real presence of Christ, the early church in the New Testament was inspired to serve the Lord and one another through corporate worship. Moreover, Christ-centered worship became the major priority for the new believers, and service through worship became their mission.

Even though our study is concerned with corporate worship, the biblical principles can be applied in any context of a personal or corporate worship experience. Whatever setting church leaders find themselves in, be it at home before the Lord, in a small-group setting, or in a corporate worship experience, they must come to the Lord looking forward 
to having these two experiences:

1. For their personal worship: times of unbroken communion with God, the sharing of thoughts and emotions with Him; worship that cultivates an authentic interchange of love between God and the individual; the clear and sensible presence of God in restoration and salvation.

2. For the corporate worshipers, people who are thirsty to come into God's presence, hungry for communion with Him: reaching out to God with joyful surrender; submissive to each of His approaches; all in one accord with the Holy Spirit and with each other.

As we contemplate these two avenues of the worship experience, it is important to remember that the quality of personal worship plays an important role in enhancing the corporate worship experience.

It is appropriate for church leaders to look both to the Bible and to current literature for helpful insights in order to improve their corporate worship services. The aim of loving Christian leaders should be to help lead the people of God and His church to a fuller realization of His will for them in becoming true worshipers. In order to do this properly, leaders must care for the flock and ensure that the needs of the people are met. They must create opportunities for involvement, creativity, spontaneity, and development of spiritual gifts, all under the influence of the Holy Spirit. As leaders fulfill these roles, they and the whole church body will move forward to experience worship improvement and the inexhaustible possibilities contained within the will of God.

In order to ensure the quality of corporate worship and help individual members to 
offer God the best according to their respective gifts, church leaders must seek to Assess, Plan, Implement, and Evaluate (APIE) the worship elements of their church. It is, therefore, necessary at this point to look at the current worship practices of the small SDA church and its challenges for revitalization, and discuss those in the light of principles taken from current worship literature for leading worship. 


\section{CHAPTER 3}

\section{WORSHIP IN THE SMALL SDA CHURCH: OFFICIAL GUIDELINES AND SUGGESTIONS}

Going to church is a way of life for most people in the Seventh-day Adventist Church. They take worship seriously and are worshiping in increasingly diverse ways. Gone are the days when a simple order of worship printed in the Sabbath bulletin sufficed to define the order of SDA worship. Congregations are now experimenting with new forms of liturgy, different styles of music, and alternate ways of worshiping God and reaching His people. Adventist worship, once resounding with a heavy English accent, has now become an exuberant chorus sounding the voices of many "tribes and peoples." Leading worship, a task once reserved for pastors, is now likely to involve a broad cross section of members serving as planners and participants.

Corporate worship in the SDA church emphasizes both the transcendent and eminent character of God: God is great and God is here, God is above us and God is among us. ${ }^{1}$ Church leaders should seek to become specialists in leading the congregation into a true worship experience.

For SDA church members, the Sabbath worship service is the most important of all

'General Conference of Seventh-day Adventists, Seventh-day Adventist Minister's Handbook (Washington, DC: Author, 1997), 145. 
the meetings of the church. The Church Manual suggests that worshipers should gather week by week to unite in a spirit of praise and thanksgiving, to hear the Word of God, to gather strength and grace to fight the battles of life, and to learn God's will for them in soul-winning service.' The manual further indicates that reverence, simplicity, and promptness should characterize the whole worship service. ${ }^{2}$

The SDA church believes that worship of God is based on the premise that He is our Creator and we are His creatures (Ps 95:6; Rev 14:7), and that Creation is the foundation of true worship. ${ }^{3}$ Consequently, true Christian worship is centered in God and focused upon Him. At the same time, worship around the world may take different forms and use different symbols as expressions of public or private worship. However, it will be truly worshipful only so long as it leads to a personal encounter with God. ${ }^{4}$

According to the Seventh-day Adventist Elder's Handbook:

1. Worship includes adoration. Meaningful worship is concerned more with the attitude with which we approach worship than with the form or order our worship takes.

2. Worship includes proclamation. Worship is a time for the proclamation of

${ }^{1}$ General Conference of Seventh-day Adventists, Seventh-day Adventist Church Manual, 16th ed. (Hagerstown, MD: Review and Herald, 2000), 71.

${ }^{2}$ Ibid.

${ }^{3}$ General Conference of Seventh-day Adventists, Seventh-day Adventists Believe (Washington, DC: Author, 1988), 74.

${ }^{4}$ General Conference of Seventh-day Adventists, Seventh-day Adventist Elder's Handbook (Washington, DC: Author, 1994), 137. 
God's Word. It includes the study of God, and studying God results in love and joy for knowing Him better.

3. Worship includes renewal. The result of worship should be renewal. It involves reflection, prayer, meditation, repentance, and supplication for Christ's forgiveness.

4. Worship includes fellowship. Corporate worship is vital to maintaining the strength of the body of Christ. All Christians are encouraged to unite with other believers in a community of worshipers (Heb 10:25; Col 3:16).

5. Worship includes participation. When church leaders encourage the participation of members in the worship service, the feeling of community in the church will be promoted. ${ }^{1}$

The life of an Adventist Christian should be a day-by-day experience seeking for spiritual rebirth, joyful reconciliation, faithfulness, and humble obedience to God ( 2 Cor 5:17; Phil 2:5-8). Whatever a Christian does, or is involved in, including the worship service and meetings of the church, should be a testimony of this new life in Christ and a sharing of the fruits in the Spirit. ${ }^{2}$ Accordingly, the local congregation, in a corporate way, should be fulfilling the purpose of the SDA church, which is (1) to worship God for His creative work and for all the benefits of His salvation; (2) to understand His Word, His teachings, and His purposes; (3) to fellowship with one another in faith and love; (4) to witness about one's personal faith in Christ's atoning sacrifice at the cross; and (5) to learn

'Ibid., 138-9.

${ }^{2}$ Seventh-day Adventist Church Manual, 67. 
how to fulfill the gospel commission of making disciples in all the world (Matt 28:19, 20). ${ }^{\prime}$

The Sabbath morning worship service in the small SDA church usually follows the format suggested by the Church Manual using two main divisions: the congregational response in praise and adoration —expressed through song, prayer, and gifts—and the message from the Scriptures. ${ }^{2}$ Although the Church Manual does not prescribe a set format for corporate worship, a short order of service is usually better to assist the church in achieving a genuine spirit of worship. The suggestion is that "the opening exercises should not, under any circumstances, consume time required for worship and for the preaching of the Word of God." Conversely, observation indicates that some churches spend more than thirty minutes in opening announcements despite having a pre-printed format in the bulletin.

Most small SDA churches choose to follow one of the worship service formats presented in the church manual:

1. The longer order of worship includes an organ prelude, announcements, the entrance of the choir and the ministers, the doxology, the invocation, a Scripture reading, a hymn of praise, prayer, an anthem or special music, the offering, a hymn of consecration, the sermon, a hymn, the benediction, the congregation standing or seated for a few moments of silent prayer, and an organ postlude.

'Ibid.

${ }^{2}$ Ibid., 72.

${ }^{3}$ Ibid. 
2. The shorter order of worship contains announcements, a hymn, prayer, the offering, a hymn or special music, the sermon, a hymn, the benediction, and the congregation standing or seated for silent prayer. ${ }^{1}$

It is interesting to note that many churches have traditionally used the same format and order of church service for years. Members know by memory what is going to happen in the church service even before they get there. For many, the spontaneity of the Spirit no longer exists and worship has become too predictable. Decade after decade they make the same announcements, sing the same songs, and pray the same type of prayers, without considering any creative alternatives. They act as though the suggestions offered in the Church Manual are hard and fast rules, instead of a starting point for creating a vibrant worship service.

Church leaders, especially elders, should follow the advice given in the Elder's Handbook which encourages worship leaders to respect diversity in worship styles when they result from cultural differences. Unfortunately, most elders fear to be accused of adapting worship to contemporary changes in society. ${ }^{2}$ There is a need for improvement and revitalization of the worship service in the small SDA church, making it more vibrant and relevant to all. Too often "we do not obtain a hundredth part of the blessing we should obtain from assembling together to worship God." ${ }^{3}$ We often fail to make room

'Ibid., 88.

${ }^{2}$ Seventh-day Adventist Elder's Handbook, 137.

${ }^{3}$ Ellen G. White, Testimonies for the Church, 9 vols. (Mountain View, CA: Pacific Press, 1948), 6:362. 
for the Holy Spirit's prompts which would guide us to a more perfect form of worship. Ministers and church leaders of the SDA church are invited to consider some ingredients of worship based on Rev 14 and described in the Seventh-day Adventist Minister's Handbook:

1. Adventist worship should be awe-inspiring. The first angel declares, "Fear God and give glory to Him" (vs. 7 NKJV). We give glory to Him because He portraits the eternal gospel; because He made the heavens, the earth, the sea, and the spring water; and because the hour of His judgment has come. We worship Him because He is the Creator of the universe, our Creator, and my Creator. He is also the re-Creator of this earth and the re-Creator of our broken lives. He gives us hope of restoration so we can worship Him for eternity. "Fear" suggests reverence and awe. Friendly churches may provide an opportunity for warmhearted feelings and good relationships with other worshipers, but fellowship must not be misunderstood as worship. True worship involves having warmhearted feelings toward God. Corporate worship must lead God's people into God's throne room. In reality, the primary purpose of worship is not to feel good, but to see God and be in His presence. Ellen G. White amplifies this idea of inspiring worship: Unless correct ideas of true worship and true reverence are impressed upon people, there will be a growing tendency to place the sacred and eternal on a level with common things, and those professing the truth will be an offense to God and a disgrace to religion. ${ }^{1}$

2. Adventist worship should be joyful. Rev 14:2-3 describes God's redeemed people in worship: "The sound I heard was like that of harpists playing their harps. And

'Ibid., 5:500. 
they sang a new song" (NIV). They should be joyful because they have a message to proclaim to every nation on earth, an invitation to all mankind to join in the singing of the new song of redemption. It is a song of remembrance, of faith, and of hope, a song about the Lamb who has slain for the sins of the world. It is a song about His creative power, His redemptive love, His daily care from heaven, interceding for us, and His glorious return. This text reveals that joy is a part of worship. Preparing for heavenly worship means to be prepared for joyful worship. To sing it together today in worship is to rehearse for that great day when His people will join the heavenly hosts in everlasting praise of the Father and the Son.

3. Adventist worship should be experiential. Rev 14:3 speaks about a song that "no one could learn" (NIV). Why? Because it is a song of personal experience. Nobody else can do it for us. Worship is experiential. Worship is not a routine. It is not a tradition. It is not a passive spectator sport. Worship is an event, a happening, a personal interaction between the Creator and the created. Worship is encounter.'

\section{The Worship Experience}

Although the Bible does not prescribe an order of worship, it is the church's basic orientation and authority for private and corporate worship. The Bible reveals the God we worship and the kingdom established by the crucified and risen Christ. The Bible commands worship, shows us the Christian community in corporate worship, and in its totality gives us the raw material for making certain claims regarding worship.

${ }^{1}$ Seventh-day Adventist Minister's Handbook, 145-6. 
For a member of the SDA church, corporate worship is not a substitute for private devotions. Rather, each life lived in personal relationship with God brings an indispensable contribution to the corporate worship experience. Segler indicates that worship experience should involve at least three main factors: the worshiper, the power of the Holy Spirit, and the human leadership provided in the order and conduct of worship. ${ }^{1}$ In like manner, the SDA leader should be encouraged to integrate his/her personal experience under the leadership of the Holy Spirit, and, by following Bible principles, seek to provide a meaningful worship experience every Sabbath morning. Ellen G. White describes this experience as true worship:

The religion that comes from God is the only religion that will lead to God. In order to serve Him aright, we must be born of the divine Spirit. This will purify the heart and renew the mind, giving us a new capacity for knowing and loving God. It will give us a willing obedience to all His requirements. This is true worship. It is the fruit of the working of the Holy Spirit. By the Spirit every sincere prayer is indited, and such prayer is acceptable to God. Wherever a soul reaches out after God, there the Spirit's working is manifest, and God will reveal Himself to that soul. For such worshipers He is seeking. He waits to receive them, and to make them His sons and daughters. ${ }^{2}$

True worship is not a human invention; rather, it is a divine offering. God offers Himself in a personal relationship, seeks for people to worship Him, and people respond. God's offer of love invites response in worship. ${ }^{3}$

Worship has different meanings for different people. To many, it means going to

'Segler, 239. 189.

${ }^{2}$ Ellen G. White, The Desire of Ages (Mountain View, CA: Pacific Press, 1940), ${ }^{3}$ Segler, 5-6. 
church. For others, it involves quiet meditation at home or out in nature. The environment may largely influence the worship experience, but worship is not determined only by environment. ${ }^{1}$

Some members go to church to see their friends. Others go because they like the preacher, or the music, or perhaps the sound of the organ or the choir. Again, these things may not necessarily be part of true worship. Worship is not a religious activity to be performed out of duty or to be observed by a spectator. It is not something to be watched. It is something to become involved in and to own. True worship involves an attitude of mind where worshipers immerse themselves in the worship experience. It is a giving as well as a receiving event. ${ }^{2}$ Worship "embraces both understanding and emotions." ${ }^{\prime 3}$ It means communication with God in the broadest sense of the term. This communication happens at the individual level, elevating the corporate worship experience for all.

\section{Description of Worship}

Christian worship goes beyond definition. It can only be experienced. A living worship experience may be analyzed, but it cannot be completely contained in formulas, creeds, and worship services. ${ }^{4}$

'Alf Birch, "What Is Worship?" Record [South Pacific Division], June 1991, 4. ${ }^{2}$ Ibid.

${ }^{3}$ D. A. Carson, Worship: Adoration and Action (Grand Rapids, MI: Baker Book House, 1993), 17.

${ }^{4}$ Segler, 7. 
Although the desire to worship is universal, confusion often arises about the meaning and nature of worship. While efforts to define worship may seem inadequate, certain aspects of worship need to be described. According to Franklin Segler, the following descriptions may aid in clarifying both private and corporate worship.

1. Mystery. Worship is both revelation and mystery. A worshiper experiences the presence of God in revelation and stands in awe of God in the face of mystery. God both reveals and withholds at the same time. While worshipers can be conscious of God in their lives, they can never fully comprehend the ultimate meaning of God. In worship, they experience both mystery and revelation.

2. Celebration. Worship is essentially the celebration of the acts of God in history: His creation, providence, covenant of redemption, and redemptive revelation through Jesus Christ. Worship is indeed a celebration of the gospel. Worshipers worship in appreciation for what God has done.

3. Life. Worship is not limited to acts of devotion, rites, and ceremonies. For Christians, worship is synonymous with life, with encounter. Encounter is not just a feeling, a fleeting moment spent with someone else. Real encounter implies "confrontation." Genuine encounter is a life-changing event which transforms and changes our lives in a concrete way, our relationships, our life style, our spiritual

'C. Raymond Holmes, Sing a New Song! (Berrien Springs, MI: Andrews University Press, 1984), 10. 
discipline. Encounter with God is also the reforming and transforming event that is God's gracious gift which provides a new context, a new story, a new goal, and a new identity for the believer, and leads on to growth in faith (1 Thess $1: 9 ; 2: 12)$ Acts of worship are more meaningful when the whole life is devoted to God. And the life one leads is a direct reflection of the quality of worship being experienced. Rom 12:1 says that we are to offer our bodies "as living sacrifices, holy and pleasing to God-this is your spiritual act of worship." Giving ourselves, wholly and completely, unto the Lord, is worship.

4. Dialogue. Worshipers experience God in a conscious dialogue. Worship is both revelation and response. God takes initiative in revelation, and humankind responds in worship. God is revealed to the worshiper's spirit through the Holy Spirit, Bible, and other worship elements such as music, prayer, etc. Humans respond to God through words, music, and acts.

5. Offering. The purpose of worship is not primarily to receive blessings from God but to make offerings to God. Worship is first of all the offering of self, intellect, feelings, attitudes, and possessions to God.

6. Eschatological fulfillment. Worship is the eschatological function of the church. It is the very essence, the continuing decisive working out of salvation in history, which ends in the eternal adoration of God. In worship, humanity anticipates that coming time when worshipers shall be gathered together around God's throne in heaven.'

It must be remembered that corporate worship is never just what the local congregation offers to God. The church is nothing if it is presented as an isolated group

${ }^{1}$ Segler, 7-8. 
of worshipers. When we come together in corporate worship, we are emulating what corporate worship will be for eternity. The Psalmist says, "I will praise the name of God with song, and will magnify him with thanksgiving" (Ps 69:30). The local church joins with the eternal Church triumphant and all the multitudes of heaven to praise Him. Therefore, with angels and with all the company of heaven, we all, and in a loud voice, magnify His glorious name every time we come together to worship. Again the Psalmist says, "O magnify the Lord with me, and let us exalt his name together" (Ps 34:3).

\section{Actions of Worship}

For the most part, SDA churches lack Christ-centered corporate worship. Many lack an understanding of basic corporate worship principles. Often worship revolves around the practice of "l" and "me" rather than "we" and "us" in the God-and-human relationship. Sometimes church leaders take advantage of their positions in order to push their own tastes and personal worship biases on the congregation, forgetting that corporate worship centers around the needs of all members.

Robert Webber explores eight principles that should be considered in guiding corporate worship:

1. Worship celebrates Christ. It is the proclaiming of God's saving work through Christ in song, story, prayer, and thanksgiving.

2. Worship tells and acts out the Christ event. The order of worship is designed to reveal God's action in history. Through that order, the worshiping community meets the God who has acted and who continues to speak and act among His people. 
3. In worship God speaks and acts. If worship is truly rooted in the gospel and celebrates Christ, then people can expect a divine action to occur in worship, revealed through words and signs.

4. Worship is an act of communication. Communication takes place in worship when the Lord speaks and acts and the people of God respond. Worship employs both the spoken word and the symbolic act so that God can touch all areas of an individual's life and communicate with people of varying personalities.

5. In worship, people respond to God and to each other. More than an intellectual assent to doctrine or prayer, worship is an experience of the presence of a holy God.

6. Worship is an act of the people. Worship is not a service or entertainment performed for the laity; it is an act that requires the participation of all members in the body of Christ.

7. Worship makes effective use of God's creative gifts. The Bible envisions worship as an offering of the entire person in living sacrifice to the Lord.

8. Worship is a way of life. Worship is not an action limited to the weekly church service. It is a way of life that the church experiences through each of its members day by day. ${ }^{1}$

Taking these principles into account, church leaders should strive to help worshipers experience uplifting worship-to have the satisfaction of an experience in

'Robert Webber, The Complete Library of Christian Worship (Nashville, TN: Star Song Publishing House Group, 1994), 2:370-6. 
which they find communion, response, involvement, and a life-enriching experience. The art of balancing these elements of worship, resulting in worshiper satisfaction, is a continuous challenge.

\section{Challenges in Church Worship}

As we continue to examine the corporate worship experience of the small SDA church, two extremes emerge. One extreme is worship which is ornate, ceremonially elaborate, and complex in formalism. The other extreme is a formless worship, extemporaneous and unplanned, confusing, and poverty stricken. Either extreme is unhealthy and must be avoided in worship services. ${ }^{1}$

Church leaders, by virtue of their calling, are leaders of worship. Since worship is an art, leaders of worship should be artists. They should embody the spirit of worship, inspire a sense of reverence in others, and develop the skills that enable them to lead worship in an acceptable and attractive manner. ${ }^{2}$

Church leaders should not forget that the human aspect of worship, as in any other endeavor, needs to be improved continuously. There is the temptation to develop a reasonable, satisfactory order of service and repeat it ad infinitum. The only change made through the years is the number of the hymn and the sermon title. ${ }^{3}$

${ }^{1}$ Class notes for "Worship Workshop: Church Leadership Training Program," Sao Paulo, SP, Brazil, January 1995.

${ }^{2}$ Class notes for "Corporate Worship Renewal Seminar," Curitiba, PR, Brazil, February 1992.

${ }^{3}$ Class notes for "Program in Public Worship Development," Brasilia, DF, Brazil, July 1994. 
Worship practices in small churches present a challenge for those hoping to restore and provide a more biblical, meaningful aspect to the worship service. A faulty understanding of the nature and purpose of worship, combined with local cultural idiosyncrasies, has produced a variety of unhealthy worship practices in many small churches. These have resulted in weak, dry, or uninspiring worship services and fail to produce a meaningful encounter between the people and God. Terry Wardle presents some concerns which might create awareness in this area:

1. Sermon-centeredness. A worship service is more than believers gathering to listen to a sermon. In many churches, the focal point of the worship service is the proclamation event. When that is so, corporate worship suffers. Anything done before or after the sermon becomes of lesser value.

2. Leader domination. Leaders are often too involved in the worship service. Some churches expect pastors or lay leaders to perform all ministries. The worship service must go beyond the pastor or local leader. Member involvement in worship can open the door to a new power and excitement.

3. Spectator mentality. For many members, a worship service is similar to attending a concert. Worship is a spectator event. This trend grows directly from domination by the leader. The fewer people called upon to participate, the more passive worship becomes.

4. Predictability. Worship services become overly predictable. Members are familiar with what is happening; the sublime, magnificence, and renovation are eliminated. 
5. Traditionalism. Form and order of worship are often dictated purely by tradition. The worship service certainly should be sensitive to tradition but not completely determined by tradition. Form of worship should not be institutionalized.

6. Irrelevance. What happens in worship is not always relevant to daily living. People will not embrace Christianity simply because the message is true. Form, order, and message in worship should be relevant to the culture, language, and experience of daily living.

7. Lack of an encounter with God. People often do not encounter God in worship. They leave church without sensing His presence in worship. The entire experience becomes an exercise in human effort. Where and when this is true, people leave the service much as they entered it.'

These worship obstacles exist in some small SDA churches. Leaders must become introspective, paying more attention to these challenges in order to make church worship more attractive and meaningful. When church leaders in small congregations understand the deep meaning of worship, they will improve the worship service of the whole church. It is not uncommon, when a member leaves the church, for church leaders to assume the member has a spiritual problem which must be addressed. Rarely do they consider that the worship service may be pushing people away from God. If the small SDA church is to bolster its responsibility in fulfilling the "Great Commission," it must confront and solve some of these problems.

\footnotetext{
'Terry Howard Wardle, Exalt Him! (Camp Hill, PA: Christian Publications, 1988), $11-21$.
} 
Robert Webber lists some symptoms of the unhealthy worship service: (1) The congregation is passive and lacks enthusiasm and a spirit of joy; (2) visitors do not feel welcome or drawn into the community and its worship; (3) worship is cerebral and oriented almost exclusively toward teaching; (4) worship is evangelistic and oriented almost exclusively toward conversion; (5) communication skills in preaching and leading worship are weak; (6) sermons tend to be long, didactic, and lacking in application; (7) communion is celebrated infrequently as part of the worship service; (8) people sit in a manner in which vision is blocked or attention is diverted; (9) singing lacks life and most selection of music is limited; and (10) people have no sense as to the order of worship nor when it will finish. ${ }^{1}$ Certainly, awareness of these symptoms could help leaders of small SDA churches to improve church worship.

This is not just a regional problem. Observing small SDA churches in South and North America, Europe, and the Orient over the past ten years indicates that the following characteristics are often present in worship services: coldness and a dead atmosphere; ceremonial and formal formality, lack of power; indifferent behavior, no amens, no responses, drowsy indifference; not interesting, dry format, sleepy services, monotony, and lifeless singing. Church leaders must remember that many of the same negative characteristics caused problems in the early Adventist church, and counsel was received regarding how to revitalize and improve the corporate worship experience.

\footnotetext{
${ }^{1}$ Webber, The Complete Library of Christian Worship, 3:101.
} 


\section{The SDA Pioneers and Corporate Worship}

Some leaders of small SDA churches tend to think that all congregations should follow the same model, sequence, and order of worship, with no space for diversity and creativity. This, in fact, comes in direct opposition to the principles, counsels, and suggestions presented in the Scriptures, in the writings of Ellen G. White, and in the church manual. In reality, these sources teach that corporate worship should be an alive and vibrant experience.

Experiences in the early Adventist church suggest that what is appropriate for one congregation today might not be appropriate for another. There is a place for creativity, improvement, and enthusiasm. An examination of Ellen G. White's writings reveals her advice to the early SDA church:

1. Praise God with a loud voice.

But God will have a people on the earth that will not be so cold and dead but that they can praise and glorify him. He will receive glory from some people, and if his chosen people, who keep his commandments should hold their peace the very stones would cry out... With such a prospect as this before us, such a glorious hope, such a redemption that Christ has purchased for us by his own blood, shall we hold our peace? Shall we not praise God, even with a loud voice, as the disciples did when Jesus rode into Jerusalem? Is not our prospect far more glorious than theirs was? Who dare then forbid us glorifying God, even with a loud voice, when we have such a hope, big with immortality and full of glory? We have tasted of the powers of the world to come, and long for more. My whole being cries out after the living God, and I shall not be satisfied until I am filled with all his fullness.'

2. Voices united in praise and prayers to God bring forth the Holy Spirit.

November 26, at our season of prayer in the morning, we were led out to pray fervently that God would especially bless my husband, and give him a large measure of

'Ellen G. White, "To the Brethren and Sisters," Review and Herald, 10 June 1852, 21. Emphasis in all the following quotes has been supplied. 
His Holy Spirit. The Spirit of God rested upon us, and we were especially revived and strengthened in the Lord, and we united our voices in praise to God.... We all had an unusual spirit of prayer. Heaven seemed very near. We felt the sanctifying influence of the Spirit of God; not a cloud intervened between us and our Saviour, and unspeakable gratitude filled our hearts, and we could not hold our peace. We shouted the high praise of God for his rich and precious blessing which was by us more highly prized than any earthly treasure. How rich, how exceedingly precious, seemed the promises of God!

3. Blessings come as we experience freedom in prayer.

All who engaged in these seasons of prayer were greatly blessed. They not only felt a burden of prayer for my husband, but in their own behalf. With brokenness of spirit, with their faces bathed in tears would these servants of God entreat that a deep work of grace might be wrought in their own hearts. Shouts of victory, and praise to God ascended to Heaven for his tokens of love and acceptance. I never enjoyed greater freedom in prayer. We had the assurance that our petitions were heard. We were often so refreshed with heavenly showers of grace that we could say, "My cup runneth over." We could weep and praise God for his rich salvation. ${ }^{2}$

4. Songs of rejoicing, victory, and praise bring forth the sweet spirit of Christ.

And you who have been hanging on to the skirts of Zion, we want to hear your songs for rejoicing ere this meeting shall close. We want to see you stand in the congregation of the saints, and say, Hear what the Lord has done for me. We want to hear your voices speaking forth the honors of your Redeemer. We want to hear songs of praise from lips that have not sounded his praise for months. We want to hear shouts of victory from those that have been overcome. We want to have the sweet Spirit of Christ come freely into our midst. We want the waters of salvation to flow here. And we want all to take hold of the work together. Shall we take right hold together, and sweet union and love be here, melting, and cementing, and uniting our hearts together as one? Oh, that here we might triumph in God! ${ }^{3}$

Why not awake the voice of our spiritual songs in the travels of our pilgrimage? Why not come back to our simplicity and life of fervor? The reason why we are not more

97.

'Ellen G. White, "Our Late Experience," Review and Herald, 27 February 1866,

${ }^{2}$ Ibid.

${ }^{3}$ Ellen G. White, "Remarks by Mrs. E. G. White, at the Tent-Meeting in Oakland, July 2, 1869," Review and Herald, 17 August 1869, 57. 
joyful is that we have lost our first love. Let us then be zealous and repent, lest the candlestick be moved out of its place.'

5. Seek for powerful worship.

The course taken by the hardhearted and impenitent inhabitants of the doomed city is similar to the attitude of churches and individuals toward Christ at the present time. They neglect His requirements and despise His forbearance. There is a form of godliness, there is ceremonial worship, there are complimentary prayers, but the real power is wanting. ${ }^{2}$

6. Avoid too much formality and preach energized by the Holy Spirit.

Praise the Lord in the congregation of His people. When the word of the Lord was spoken to the Hebrews anciently, the command was: "And let all the people say, Amen." When the ark of the covenant was brought into the city of David, and a psalm of joy and triumph was chanted, "all the people said, Amen, and praised the Lord." This fervent response was an evidence that they understood the word spoken and joined in the worship of God. There is too much formality in our religious services. The Lord would have His ministers who preach the word energized by His Holy Spirit; and the people who hear should not sit in drowsy indifference, or stare vacantly about, making no responses to what is said. The impression that is thus given to the unbeliever is anything but favorable for the religion of Christ. ${ }^{3}$

7. Seek to make the meetings intensely interesting and attractive.

Our meetings should be made intensely interesting. They should be pervaded with the very atmosphere of heaven. Let there be no long, dry speeches and formal prayers merely for the sake of occupying the time. All should be ready to act their part with promptness, and when their duty is done, the meeting should be closed. Thus the interest will be kept up to the last. This is offering to God acceptable worship. His service should be made interesting and attractive and not be allowed to degenerate into a dry form. ${ }^{4}$

'White, Testimonies for the Church, 6:368.

${ }^{2}$ Ibid., 5:258.

${ }^{3}$ Ibid., 5:318.

${ }^{4}$ Ibid., 5:609. 
8. Avoid lifeless manner, sleepy, and indifferent ways of leading worship.

Is your temporal business of as much consequence as the service of God? Matters where eternal interests are involved? God is displeased with your lifeless manner in his house, your sleepy, indifferent ways of conducting religious worship. You need to bear in mind that you attend divine service to meet with God, to be refreshed, comforted, blessed, not to do a duty imposed upon you. ${ }^{1}$

9. Corporate worship is not merely for personal refreshing.

While we are exhorted not to forsake the assembling of ourselves together, these assemblies are not to be merely for our own refreshing. We are to be inspired with greater zeal to impart the consolation we have received. It is our duty to be very jealous for the glory of God and to bring no evil report, even by the sadness of the countenance or by ill-advised words, as if the requirements of God were a restriction upon our liberty. Even in this world of sorrow, disappointment, and sin the Lord desires us to be cheerful, and strong in His strength. ${ }^{2}$

Every heavenly intelligence is interested in the assemblies of the saints who on earth meet to worship God. In the inner court of heaven they listen to the testimony of the witnesses for Christ in the outer court on earth, and the praise and thanksgiving from the worshipers below is taken up in the heavenly anthem, and praise and rejoicing sound through the heavenly courts because Christ has not died in vain for the fallen sons of Adam. ${ }^{3}$

10. A worship experience with the inspiration of the Holy Spirit will result in

personal strength and encouragement to others.

Let us all bear in mind that in every assembly of the saints below are angels of God, listening to the testimonies, songs, and prayers. Let us remember that our praises are supplemented by the choirs of the angelic host above. Then as you meet from Sabbath to Sabbath, sing praises to Him who has called you out of darkness into His marvelous light. "Unto Him that loved us, and washed us from our sins in His own blood" let the heart's adoration be given. Let the love of Christ be the burden of the speaker's utterance. Let it be expressed in simple language in every song of praise. Let the inspiration of the Spirit of God dictate your prayers. As the word of life is

'Ellen G. White, "The New Heart," Review and Herald, 14 April 1885, 225.

${ }^{2}$ White, Testimonies for the Church, 6:365.

${ }^{3}$ Ibid., 6:366. 
spoken, let your heartfelt response testify that you receive the message as from heaven. This is very old-fashioned, I know; but it will be a thank offering to God for the bread of life given to the hungry soul. This response to the inspiration of the Holy Spirit will be a strength to your own soul and an encouragement to others. It will give some evidence that there are in God's building living stones that emit light. ${ }^{1}$

11. Corporate worship requires excellence and improvement.

The atmosphere of the church is so frigid, its spirit is of such an order, that men and women cannot sustain or endure the example of primitive and heaven-born piety. The warmth of their first love is frozen up, and unless they are watered over by the baptism of the Holy Spirit, their candlestick will be removed out of its place, except they repent and do their first works. ${ }^{2}$

The prevailing monotony of the religious round of service in our churches needs to be disturbed. The leaven of activity needs to be introduced that our church members may work along new lines, and devise new methods. The Holy Spirit's power will move upon hearts when this dead, lifeless monotony is broken up, and many will begin to work in earnest who never before thought of being anything but idle spectators. ${ }^{3}$

Now, just now, we are to proclaim present truth, with assurance and with power. Do not strike one dolorous note; do not sing funeral hymns. ${ }^{4}$

The evil of formal worship cannot be too strongly depicted, but no words can properly set forth the deep blessedness of genuine worship. When human beings sing with the spirit and the understanding, heavenly musicians take up the strain and join in the song of thanksgiving. He who has bestowed upon us all the gifts that enable us to be workers together with God, expects His servants to cultivate their voices so that they can speak and sing in a way that all can understand. ${ }^{5}$

'Ibid., 6:367.

${ }^{2}$ White, Testimonies to Ministers and Gospel Workers, 167-8.

${ }^{3}$ Ibid., 204.

${ }^{4}$ Ellen G. White, Evangelism (Washington, DC: Review and Herald, 1970), 122.

${ }^{5}$ White, Testimonies for the Church, 9:143-4. 
Fervent enthusiasm and motivation marked the Adventist pioneers' religious experience. The same spirit shined forth in the Old and New Testament times. The challenge for the contemporary SDA church is to keep alive the worship service led by the Holy Spirit. Ronald Graybill believes that "our spiritual ancestors had livelier services than many of us would be comfortable with today."' He affirms also that anyone interested in the topic of worship "must take seriously the fact that in its early history, the Adventist Church experienced, endorsed, and encouraged a more exuberant form of worship." The Bible and the Adventist pioneers support the idea of a worship environment which continuously strives for improvement in all activities and forms of corporate worship.

In order to improve the corporate worship experience in the small SDA church, it is important to continually assess, plan, implement, and evaluate what, as a church, is happening every Sabbath morning. Toward that end, the Sao Paulo Conference offered counsel to its church leaders at the church leadership training program in 1996:

1. The goal of worship is to focus on the greatness of God rather than on ourselves or our needs.

2. The result of worship must be healing and power for living transformed lives. It must bring us into closer relationship with Jesus and with other worshipers, and then 1991,10 .

'Ronald D. Graybill, "Enthusiasm in Early Adventist Worship," Ministry, October ${ }^{2}$ Ibid., 12. 
challenge us to purposeful service in the world.

3. Worship must clearly tell the story of Jesus Christ as our only hope and must also show how His story can become ours.

4. Worship must examine and affirm what we as Seventh-day Adventists believe about God.

5. Because worship is an offering to God, it must be taken seriously and done with excellence.

6. Each worship service must be carefully and purposefully planned.

7. Each element of worship is important and must contribute to the goal of that particular service.

8. The atmosphere of worship must include celebration, contemplation, and commitment.

9. Worship must be participative for all present, not a performance for spectators.

10. Each worship service must be intensely interesting and should take advantage of the incredible power of variety.

11. Each aspect of worship must be understandable and useful for the first-time guest. $^{1}$

In summary, small SDA church leaders must strive to create an environment in which God's people are alive with the power of the Holy Spirit, one in which the service

\footnotetext{
${ }^{1}$ Class notes for "Worship Workshop: Church Leadership Training Program," Sao Paulo, SP, Brazil, January 1996.
} 
itself becomes a dialogue between God and the people of God, one in which God moves toward His people in revelation, and they, in turn, move toward God as a worship response, one in which God comes to His people full of grace, and His people respond in thankful obedience, and one in which the gospel is inspiringly preached, and God's people respond with grateful hearts of surrender.

Because this concept of worship is misunderstood in some places, it requires continual refinement and improvement. The underlying principle remains a sound one. Worship must cease to be a purely human activity, one in which worshipers are merely passive spectators; it rather needs to become an active engagement with God. Church leaders are charged with creating a worship service alive and full of His presence. What will attract worshipers is not the worship program or format, but the knowledge that on the Sabbath each will meet with the Lord and go home renewed.

A church may have many different outward attractions, but the quality of its worship remains the magnet by which people are drawn to its services. Sensationalism may bring about quick and cheap results, but relevant and satisfying worship is essential for the permanent usefulness and growth of the church. Many small churches do not realize the importance of an authentic worship experience. In many churches worship is poorly done, in a predictable, boring, and irrelevant manner. As a result, the same practices are repeated over and over again. Instead of attracting people to Christ, those churches are distracting them from Christ. Small- church leaders must recapture vitality in the life of the church. They must be provided with more instruction and training 
concerning corporate worship principles, and they should be encouraged to implement these principles in striving for worship revitalization.

Through the model presented in the next chapter, church leaders discover ways to improve and revitalize worship services through Assessing the congregation's spiritual needs, Planning properly for the worship service, Implementing those changes needed in the corporate worship service, and Evaluating the results. The APIE model will become a living improvement model that will help revitalize the corporate worship experience, ultimately bringing people closer to God. 


\section{CHAPTER 4}

\section{A MODEL OF CORPORATE WORSHIP SERVICE}

\section{IMPROVEMENT: APIE}

The APIE (Assess, Plan, Implement, and Evaluate) model is a continuous improvement model providing process skills to leaders of small SDA churches who need to be continuous "leaders," thereby contributing to worship service success. The process skills presented in the model apply to all leaders involved in delivering any of the church worship elements (i.e., music, prayer, Scripture reading, preaching the Word, offering, testimony, children/youth involvement, and benediction), whether they be pastors, elders, or other members.

The APIE model has been designed to be used by church leaders who have a desire to make the worship service meaningful to all worshipers. The APIE continuous improvement model is a structured, yet adaptable, process for improving corporate worship which will help the church achieve its vision and move in the direction it wants to go.

For corporate worship to be successful, a church must have a clear goal and direction. When church leaders are able to envision the ideal future of a church, they can develop plans and focus on efforts which move in that direction. Key areas for 
improvement should be identified. Churches that do not have a worship vision must still be able to provide information to the worshipers as to the direction they wish to take and the areas in which they need to improve. Those churches who do not have a worship vision but have been proceeding by custom should still be able to explain why they are doing things the way they are doing and thus provide some direction to the worship service.

With an increased number of churches, worshipers are able to choose their place of worship, thus requiring leaders involved in the worship service process to take on a leadership role in worshiping God and serving worshipers better, supporting the church's overall worship efforts, and involving and motivating all worshipers.

A great challenge church leaders face is that of successful interaction with worshipers. Whether they are empowering worshipers to perform certain tasks more independently or developing an environment in which worshipers can make more decisions regarding the worship service, church leaders need to know how to help each worshiper participate in worship.

For a church to survive and prosper, it must accept and meet its responsibilities to its worshipers. It must create a worship "program" which will help people come before God. A church that does not satisfy the worshiper's needs in coming before God will not survive.

In order for a church to be successful, it must see its worshipers as partners and be committed to their spiritual success. The church must have a "God-worshiper-focus" mentality. Churches need to find out directly from their members how they are doing in 
their corporate worship experience. This helps to determine their needs, expectations, challenges, and the worship elements required. A church can then focus on providing them with a worship service that will enable them to truly worship God.

In a seminar on quality assurance and improvement in 1992, Washington Olivetto pointed to a government survey which found the following to be true about customer complaints: (1) 96 percent of unhappy customers never complain about rude or discourteous treatment; (2) 90 percent, or more, who are dissatisfied with the service they receive will not buy again or come back; (3) each unhappy customer will give a history to at least nine other people; (4) 13 percent of unhappy former customers will tell their stories to more than twenty people.' Because human behavior can extend to customerlike attitudes regarding worship, it is important to improve our worship services in order to provide a better worship experience for all believers.

To be successful in a time when worshipers have choices regarding place and styles of worship, churches must deliver a worship service which will help to solve their worshipers' spiritual problems and exceed their expectations for an environment of worship to God. The church must make a commitment to continuously look for ways to improve everything it does in the elements of worship in connection with God and the worshiper. This will ensure that God as our ultimate reason for worship will be offered quality acts of worship in the corporate setting.

Small SDA churches are becoming more pressured by the ever-increasing

\footnotetext{
'Washington Olivetto, Seminar in "Building Quality Into Your Organization," Sao Paulo, SP, Brazil, May 1992.
} 
expectations of worshipers, who are demanding high-quality worship services and more involvement in the worship process. There are no shortcuts to quality when it comes to the worship service. The APIE quality improvement model for corporate worship is a never-ending cycle, requiring the full support and participation of individual worshipers, church leaders, and pastors.

Before focusing on the Assess, Plan, Implement, and Evaluate (APIE) model for corporate worship improvement, it is necessary to define, for the purpose of this dissertation, what continuous improvement means in the setting of corporate worship.

\section{Continuous Improvement}

The definition of continuous improvement may differ from one church to another. Individuals within the church leadership may even differ in their understanding of what the term means in relation to their church's corporate worship experience. For purposes of this study, continuous improvement in corporate worship is defined as everyone working together, every week, to make one hundred things 1 percent better, rather than just one thing 100 percent better, in order to fulfill the needs of the worshiper and ultimately "please" God (Ps 69:30, 31; Rom 12:2 NIV).

Our definition has eight elements: (1) Everyone; (2) Working together; (3) Every week; (4) To make; (5) One hundred things 1 percent better; (6) One thing 100 percent better; (7) Fulfill the needs of the worshiper; (8) Ultimately please God.

1. Everyone. All worshipers (i.e., pastor, elders, church leaders, members, attendees, visitors) must be involved in the continuous improvement process of corporate 
worship. Each individual worshiper needs to make a commitment to look at what he or she can do every week in order to identify incremental improvements. Continuous worship improvement is not the responsibility of one department, worship committee, or pastor. Continuous improvement of corporate worship is everyone's responsibility.

2. Working together. Even though continuous worship improvement involves all individual worshipers, it also requires teamwork to be successful. People must be able to rely on others to help them identify their spiritual gifts, areas for improvement, and new ways for using their gifts. Effective worship service takes advantage of everyone's experiences and gifts. Working together requires cooperation, communication, and initiative.

3. Every week. Continuous worship improvement must be a way of life. Such constant attention keeps the worship service attractive to visitors. Continuous improvement is not the exclusive job of the pastor. Making the continuous improvement of corporate worship a way of life in the church takes commitment from all worshipers.

4. To make. Corporate worship improvement does not just happen. It takes effort. It takes commitment. It takes an ability to see beyond the obvious or the traditional or the contemporary. Making continuous improvement in church worship requires new skills and new attitudes. It also requires a clearly articulated vision that all worshipers can understand, believe, and act upon. Only then can the actions and the elements of worship de facto get improved.

5. One hundred things 1 percent better. Continuous improvement in corporate worship is made up not only of victories, unmistakable actions, or professional 
performances. It involves making every little thing better, even if the improvement happens only in small increments. Once an element has been improved by 1 percent, the church leader continuously reexamines it, evaluating it for another 1 percent improvement at the worship service. Doing so means that all the elements of the worship service (i.e., music, prayer, Scripture reading, preaching, offering, children/youth involvement, testimony, benediction) continue to improve.

6. One thing 100 percent better. This idea seeks to improve one specific element, such as the weakest link, rather than trying to improve all elements at the same time. Too often small churches rely on the big hit to change the way they do things in weekly worship. Many times the big hit never comes, or it does not produce the expected results. As church leaders, we must look at making significant improvements in selected areas of worship elements which are particularly weak. We are challenged to examine every single element of the worship service, assess the weakness of a specific element, and work toward improving that element 100 percent.

7. Fulfill the needs of the worshiper. All continuous worship improvement efforts should seek to fulfill the worshiper's need to worship and to please God. Each person, each worship element, and each action in the worship service need to provide worshipers with the opportunity to accomplish what they came for, which is to worship God. People go to a restaurant to eat, to a stadium to watch a game, and to a church to worship God.

8. Ultimately please God. Continuous corporate worship improvement must accomplish the ultimate task of pleasing God. Within this process, the primary focus should be on pleasing God by obeying His commands, inviting all the earth to worship 
Him (Rev 14), and teaching obedience only to God and salvation through Jesus Christ, with the assurance that $\mathrm{He}$ will be with us forever (Matt 28:19-20). In focusing on God, a grateful worship environment will be created for His people.

Continuous worship improvement benefits everyone. It aids worshipers in meeting their needs to worship God, it provides benefits to the church by fulfilling God's command to minister to His people, and brings joy to our Lord who knows that all His children are coming together to worship the Creator.

The APIE continuous improvement model follows a four-step process to help church leaders as they Assess, Plan, Implement, and Evaluate their weekly worship service. In following the APIE model, church leaders are asked to consider two questions: (1) What do we have to do to please God? (2) What do we have to do to fulfill the needs of the worshiper? As pointed out above, there should be no difference between what God and the worshiper require for a successful worship experience.

When there is a dichotomy between God's requirement and the worship process actually followed by the worshipers, the whole worship process is out of balance and the following problems may result:

1. When the worshiper's needs are fulfilled, but God's requirements are not met, the worshiper's salvation is jeopardized. There is often disharmony within the church. Instead of acting as a worship center, the church becomes an entertainment center.

2. When church leaders do all the planning of the worship service without care for the worshiper's expectations or needs (reasoning that "this is His will, or this is His music, or this is God's style, or this is 'our' church, etc."), some worshipers will become 
discouraged. The worshiper's relationship with the church, and moreover with God, is at risk and the growth of the church is jeopardized. It will be hard for those looking for a personal Savior to hear His message and understand the promise of "casting all your care upon Him, for He cares for you" (1 Pet 5:7). The church, instead of being a worship center and a place of love, compassion, and caring, will become a mausoleum of legalistic saints driving dissenters away from God.

By balancing the needs of the worshiper with God's will to see His children coming together to worship Him, we can ensure that the church will find what it needs to survive and to grow, and that worshipers will find what they need in order to be satisfied and grow in their spiritual relationship with the Lord. All interested worshipers must be invited to the "table" to plan the worship service. The Lord created each of His children with a unique personality and set of needs. We honor His will by welcoming the input of each of His creatures.

Toward this end, we might consider some simple guidelines offered by Aubrey Malphurs: (1) leaders must be worshipers; (2) worship should be relevant culturally; (3) worship must be done well and beautifully; (4) worship needs a proper environment; (5) worship must be creative and innovative; (6) worship should be reverent; (7) worship should be genuine; (8) worship should be well timed; and (9) worship should be supremely God-conscious, Christ-mastered, and Spirit-led. ${ }^{1}$

The proposed APIE model provides a four-step process of continuous

${ }^{1}$ See Aubrey Malphurs, Planting Growing Churches for the 21st Century (Grand Rapids, MI: Baker Book House, 1995), 180-1. 
improvement to help the church focus on the worship service issues, opportunities or problems which have an impact on the church worship service, vision, objectives, mission, and on the identified needs of the worshipers. Few local church leaders possess knowledge of this concept, or even the need for this process. If church leaders can learn to utilize the principles presented in the APIE model, members will be more satisfied with the worship experience, churches will be fulfilling the Lord's command, and, most importantly, God will be pleased. Church leaders can use this model as a tool to improve the worship service in a four-step continuous model as they consider to:

1. Assess the congregation. This first step involves perceptive knowledge and opinions about, as well as attitudes and behavior during, the general worship service, considering its elements and the attending worshipers. In essence this step involves gathering and organizing information. It provides the foundation for all the other steps in the continuous worship improvement process by determining "What is happening now?"

2. Plan the worship service. Information gathered in the first step is used to make decisions about objectives, goals, and directions to be taken in the worship service. This second step in the model answers the question, "Based on what we have learned about the church worship service, what should we change, keep, or do and say?"

3. Implement the elements of worship. The third step involves implementing the plan of action for the worship service designed to achieve specific objectives for the local church and its members. The questions in this step are, "Who should do and say it, and when, where, and how?"

4. Evaluate the results in the church's life. The final step in the model assesses 
the plan implemented to find out the results of the actions. Adjustments can be made while the model is being implemented, based on evaluation feedback on how it is or is not working. Plans are continued or stopped after asking, "How are we doing, or how did we do?"

Each step is as important as the others, but the process begins by assessing the congregation to gather information and get acquainted with the church's reality.

Information and understanding developed in the first step motivate and guide subsequent steps in the model. In practice, of course, once the process is started, the components Assess, Plan, Implement, and Evaluate may overlap, because the model is continuous and cyclical and is applied in a dynamic setting.

\section{Step One: Assess the Worship Experience and the Congregation}

Assessing church worship elements is not only the first step in the improvement model; it is the most difficult one. One is reminded of the fable of the elephant and six blind men of Indostan: Each encounters only a single part of the beast and describes the elephant based on that limited information. For example, the one who grabs the trunk concludes, "The Elephant is very like a snake!" The one who feels the knee says, "This Elephant is very like a tree!" This process continues, with each one experiencing only a portion of the elephant. In the end, each was partly right and mostly wrong about the nature of the beast but argued "loud and long" based on his respective encounter with the 
elephant. ${ }^{1}$ Without assessing the worship situation, church leaders run the risk of acting like the six blind men from Indostan.

\section{Obstacles for Worship Improvement}

Many churches have found that, despite the best intentions, their worship improvement initiative has failed. Personal observation suggests that it is certainly not because people do not understand, or agree with, the idea of making things better.

1. Lack of communication. Often it is because the reasons for embarking on a continuous improvement journey are not properly, or fully, communicated to all worshipers. Communication is a two-way avenue that gives the opportunity to give and receive information. Often people assume that if there is someone speaking and others listening, communication is taking place. In order for improvement to happen in worship, leaders must listen to the congregation's input and receive their collaboration for worship improvement.

2. Lack of role modeling. People willing to be involved, especially young and new members, often do not see senior members of the church demonstrating the behaviors they are expecting from others to demonstrate. They do not "walk the walk." Worship leaders move others to worship by their example and not by the power of their program. The example of Jesus in role modeling people can help to improve worship service activities. He reached people were they were, He desired their good, He showed

'John Godfrey Saxe (1816-1887), "The Blind Men and the Elephant," quoted in Henry Mintzberg, "Strategy Formation: Schools of Thought," in Perspectives on Strategic Management, ed. James W. Fredrickson (New York: Harper Business Division of Harper \& Row, 1990), 105-6. 
sympathy, He ministered to their needs, and He invited them to "Follow Me."

3. Lack of awareness of the members' spiritual needs. Church leaders must remember that people have all kinds of personal and spiritual needs, and may see things from different perspectives. Indeed, their spiritual needs must be assessed before ministering to them effectively and providing a corporate worship experience. In assessing their needs we should recognize that needs arise because of different circumstances and meeting those needs is a complex matter and it may be impossible to meet their needs fully. Spiritual needs can be affected by conflicts, external or internal pressures, and can change from year to year and place to place. However, worship leaders need to be ready to adapt their ministry according to the needs.

4. Lack of involvement of other members. Some church leaders might not understand the need for member involvement and ask, "What is wrong with the way we do things in our church?" Other members complain of seeing certain individuals take personal advantage from their position (i.e., the music director always schedules him/herself to play for the main church service and others only for Sabbath school or prayer meetings; the "elder of the month" takes control of all preaching and worship activity elements, becoming a "show-man"). And then there are those who are willing to be involved and, if this does not happen, are likely to leave and attend another church.

5. Lack of commitment on the part of the members. Getting people committed to improvement and keeping them involved are two of the most important tasks the church

'Ellen G. White, The Ministry of Healing (Mountain View, CA: Pacific Press, 1942), 143. 
leader can face. Through assessing their needs and communicating with them about the church's needs, the leader will help members understand how and why the current worship service should be improved, and how their involvement in it must follow the process.

Where these attitudes and behaviors exist in a small-church setting, the probability of having a successful worship improvement initiative is greatly limited. In fact, the entire improvement process can be put at risk.

\section{Assessment Procedures}

Effective assessment in corporate worship starts with listening, which requires openness and systematic effort. The amount of information provided by members determines how the church leadership will respond to their needs. Assessment begins with someone making a value judgment that something is either wrong, could soon be, or could be better. Assessment is used to describe the current situation of the worship service and its relation to God and the worshiper. Assessing people's needs for worship gives leaders the information necessary to make the right decisions to improve the quality of worship and thus minister to peoples' needs and help them connect with God.

One of the most important things we can all do to ensure the success of the worship improvement is to adopt a God-worshiper-focus mentality in everything we do in the worship service. The church could provide a "good worship program" or a "good performance" each week, but doing good does not accomplish the mission of worship ministry. The only way we can begin to improve what we achieve and deliver every Sabbath is to improve how we help the congregation to be connected with God. It is our 
responsibility to find out how effectively the provided form of worship impacts their spiritual lives.

Three key actions help the church assess the areas of opportunities for improvement and service through corporate worship: (1) Identify the process of the worship service; (2) ask worshipers to rate how the worship service is impacting their personal spiritual lives; (3) define what the church can do to improve the worship service.

1. Identify the process of the worship service. To complete this action, the church needs to identify (a) the priorities provided in the worship; and (b) who the worshiper is.

a. The priorities provided in the worship. Usually, the worship service has a linked series of elements, actions, or activities that follow a particular sequence to intentionally produce a specific result in the congregation, helping worshipers to become more connected with God and with one another. Every worship service (i.e., long or short format; traditional, contemporary, or blended; youth/children or adult) has many tasks which must be completed. There is the challenge of involving people and determining how the service will be delivered. How a church determines its priorities in the service will depend on its vision, objectives, and mission. ${ }^{1}$ This can help the church to achieve what is needed in order to improve what the church does.

A look at the church worship priorities helps determine the delivery process and the impact the worship service aims at in the worshiper's life. These priorities can be assessed by the proposed questionnaire "Worship Elements Priorities"2 which provides

${ }^{1}$ See chapter 2 for Biblical Principles of Corporate Worship.

${ }^{2}$ See Appendix A. 
tools to analyze the elements of the worship service. This helps the church leaders identify which element of the worship service to look at first for improvement.

b. Who the worshiper is. As the church leaders have already identified the priorities of the worship service, as well as the worship-outputs of each worship service, it is important to identify who receives the worship-outputs delivered during the weekly worship service. In other words, who are the worshipers we are delivering the worship to?' In assessing the congregation, leaders should seek to understand their worshipers' expectations, spiritual needs, and level of satisfaction related to what is provided to them in the corporate worship service. A list of questions or areas of focus which relate to the elements contained in the worship service can be generated for worshipers. For this purpose the leader may use the suggested proposed survey "Your Personal Evaluation of the Worship Service in Our Church,"2 which can be given to every member and is related to their involvement and the performance of the worship service in their church. This questionnaire is a tool that helps provide information for both the assessment and evaluation stage. Members will have the opportunity to share information about themselves and how the worship service is affecting their spiritual life.

Worship leaders should also seek to obtain feedback from who are not attending the church service anymore to assess their needs, why they left, and try to shape the

'Contrary to what is generally done, I do not embrace the idea to assess the church constituencies in terms of social, economic, ethnic, or educational age differences. I believe that the need lies on a different level.

${ }^{2}$ See Appendix B. 
service in such a way that it attracts them again in the context of fulfilling their spiritual needs.

As leaders assess priorities of worship and the needs of their congregation (i.e., members, former members, and visitors) they will recognize that if the worshiper does not find fulfillment in his church, he/she will exercise the freedom to chose a church that responds to his/her spiritual needs and expectations. Each worshiper has a choice to come and worship or go and receive the same worship-outputs from another church-in most cases, a church less than thirty miles away. If people can drive over fifty miles for a good meal in a good restaurant, they will drive over fifty miles to attend a well-prepared worship service in a church that is concerned with their spiritual needs and provides them with the spiritual meal needed.

\section{Ask worshipers to rate how the worship service is impacting their personal} spiritual lives. In assessing the congregation, do not be afraid to ask them questions. Asking the members what they think about the worship service, how the worship-outputs impact their spiritual life, and what they want us to know about their needs will help the church provide a more relevant service. As you consider the church's vision, objective, and mission, what would you like to ask them? Generate a list of questions related to the specific elements in the worship service they attend, and those related to the church vision. The answers will determine how we can improve the elements of the worship services delivered to them, and the answers tell us how the worship service is received. Their comments will help us to understand their expectations and their level of spiritual fulfillment related to what we have delivered to them in the worship. 
The church leaders must approach the congregation with the question "How did we deliver worship?" for each element of the worship service or apply the same question for each "worship-output" during the worship service. A worship-output is defined in this dissertation as the result of any action, element, or format that conveys a worship experience (i.e., music, prayer, Scripture reading, preaching, offering, children/youth moment, testimony, benediction). To assess the worship-outputs, the church leaders should ask this basic worship-output question: What other action, element, format, or result could be delivered in order to create a better corporate worship experience for the worshiper? Each element of the worship service should provide a worship-output. While it could be identified as either positive or negative, the leaders should take time to describe the result obtained with each worship element in relationship to the objectives of the church.

Two tools are proposed as a sample for assessment and gathering information: The Worship Inventory Survey and the Worship Experience Questionnaire.

The sample "Worship Inventory Survey"l provides the church leaders with an idea as to what the survey could look like and help the church refine its own questions. The success of corporate worship improvement can depend to a great extent on how well we assess and determine the worshiper's need. This can become a very challenging task, which the pastor cannot do alone. The pastor and church leaders should consider to work as a team to help each other in the development of the worship survey. Working as a team provides an opportunity to get everyone involved early in the worship improvement 
process, and can help to build up commitment and ownership into what needs to be done later when dealing with the worshipers' expectations.

The other assessment tool it is called "Worship Experience Questionnaire." This is a simple questionnaire asking five questions such as this: In our endeavor to provide you with a satisfactory corporate worship experience, (1) What are three things that we do well now which you want us to keep doing/providing? (2) What are three things that we do now which you would like to see us stop doing/providing? (3) What are three things that we do not do now which you would like us to start doing/providing? (4) How do you feel we compare with other churches' worship services you attended? (5) What are some of the trends in your spiritual life that you feel we need to know to help you connect better with God?

When the church decides to use a worship inventory survey or a questionnaire, it can also choose to send a "Worship Survey Sample Letter"" explaining its intentions in doing so.

Another important factor in the assessment of continuous worship improvement is to consider sitting down with the worshipers to discuss their feedback. This is, of course, more easily achieved in small churches. The church leaders should use this opportunity to really understand their members' expectations and suggestions. Surveys and questionnaires certainly help worshipers to 'tell their story', but a face-to-face meeting

'See Appendix D.

${ }^{2}$ See Appendix E. 
focusing on 'why' they appraised the worship service the way they did may be of real assistance.

3. Define what the church can do to improve the worship service. Once the worshipers have completed the survey or questionnaire, the leadership is able to gather the data, break down the information, and average what was said in order to define priorities that will help to build up the worship service. The purpose of the survey is to assist the advance of the church worship improvement efforts. The worshiper's feedback helps the leaders to choose on which worship service priority to concentrate. Church leaders should be aware that the ultimate improvement sought after is to see Jesus lifted high in our corporate worship and in the worshiper's life.

In order to make right decisions in determining priorities for the planning of the worship service, church leaders need to consider, in the light of the biblical principles and the results of the assessment, what is important to the worshiper and brings them satisfaction (i.e., whether the local worship-outputs truly help them to worship God and come closer to Him).

Considering that the ultimate desire of the congregation is to worship and serve God when attending a worship service, the following examples could help the church to choose its priorities better in order to improve, maintain, or discontinue some of its worship-outputs. These examples could be applied to any of the worship-outputs if the ultimate purpose is to provide the worshiper with a meaningful worship experience with God.

a. Worship-outputs elements with low satisfaction and high importance should be 
given high priority for improvement. In other words, the church should begin by focusing its efforts on improving and dealing with the issues defined by the congregation.

b. Worship-outputs with high satisfaction and high importance should be given high priority for maintenance. The church must be sure why it received high satisfaction ratings for these worship-outputs so that it can continue to provide the level of worship service and experience the worshipers view as being important to them to worship God.

c. Worship-outputs with low satisfaction and low importance should receive low priority. Since the worshipers find that these worship-outputs are not only unsatisfactory but also unimportant to their worship experience, the church should consider whether or not to continue to provide that worship-output (i.e., why push to start the worship at ten o'clock when the worshipers prefer eleven o'clock; or why insist using organ accompaniment when worshipers prefer singing with the piano and an additional variety of instruments).

d. Worship-outputs with high satisfaction and low importance should also receive low priority. In some sense, the worshiper is saying that the church is providing a worship-output they are satisfied with, but it is not viewed as a requirement since it received a low importance rating (e.g., some leaders spend many hours in technology and Power Point presentations as a tool to support their program which is seen as satisfactory but not important to this kind of worshiper).

The church leaders may need to take a look at the worship elements that do not help to provide an intensive and meaningful worship experience and consider whether or not to discontinue them. 
In assessing the congregation, church leaders should remember that worshiper expectations change. As their needs change, so too might their expectations as they relate to the worship-outputs of the Sabbath corporate experience. Just because one element in our worship service is not at the present time important or satisfactory to provide a better experience to the worshiper, does not mean that it will stay that way.

In summary, assessment information, combined with church leadership experience and Christian judgement, provides the foundation for defining corporate worship needs and for creating worship services to address those needs. In other words, assessment builds the information foundation necessary for an effective worship service maintenance and its improvement. Church leaders should know that assessment initiates, monitors, and concludes the APIE improvement model. It is the essential ingredient that brings opportunities for creativity in the worship service.

Finally, assessment as step one of the APIE model helps the church to stay in touch with the worshipers, helps to pay attention to their specific areas of interest, and helps to keep pace with their changing needs, as the church continuously improves its corporate worship experience.

\section{Step Two: Plan the Worship Service}

In order to implement the decisions made at the assessment level to improve the elements of the worship service, the leaders must first create a plan of action.' Step two of the APIE model of continuous improvement in corporate worship suggests a need for

${ }^{1}$ See Appendix F for Worship Planning Worksheet as a suggestion. 
church leaders to create a complete plan which will enable them to visualize the purpose of the worship service, its process, and its organization. It will furthermore help them to recognize the need for involvement of volunteers, and to prioritize the worship activities in order to set up a schedule, assign tasks and deadlines, and provide the necessary resources to help each participant accomplish a meaningful part in the worship service.

Planning creates a dynamic impact on any church activity. It is the thinker who helps organize, prioritize, and activate what the churches do. Where there is no plan, there is no power. Where there is no plan, there is no direction. Where there is no plan, there are no results. Where there is no plan, there is no influence. Plans should be the brain of continuous improvement and success of the worship service.

To achieve better results in the worship service, it would be helpful to apply what Byrd Bagget suggests to remember as the five Ps, "proper planning prevents poor performance."1 Meanwhile, there is another way to remember the five Ps as we create worship weekly: Praying, Planning, Preparing, Promoting, and Professing. Praying is asking God for directions. Planning is choosing the road. Preparing is carrying the map. Promoting is trusting where we are going. Professing is delivering the mission.

A meaningful worship service, suggests Paul Basden, hardly ever happens by osmosis. It requires careful preparation. This involves planning, leading, and evaluating the service. In planning worship, one main question needs to be asked: "What are we

${ }^{1}$ Byrd Baggett, The Book of Excellence (Nashville, TN: Rutledge Hill Press, 1992), 2. 
doing here?"1 This question helps to define the purpose of worship and establish priorities.

\section{A Biblical Approach to Planning}

One biblical basis for planning is established in the words of Jesus when He says, "For which of you, desiring to build a tower, does not first sit down and count the cost, whether he has enough to complete it" (Luke 14:28 ESV). The Bible teaches that God is the great Master Planner who laid out a path for all human history even before the earth existed. Throughout the Bible, God also reveals His interest regarding both human and divine planning. In Prov 16:9 (NIV) God says, "In his heart a man plans his course, but the Lord determines his steps." We also read in Scripture, "Any enterprise is built by wise planning, becomes strong through common sense, and profits wonderfully by keeping abreast of the facts"'(Prov 24:3-4 LB). To be successful, any activity must have a wellplanned foundation. In church ministry, the wise plan is to follow plans already presented to us by God.

\section{God Has a Plan for Us}

Any organization has a mission, vision, or master plan which guides all its decisions. In the same way, God has a plan for each one of us which needs to be integrated in a corporate way into the church as we serve Him in planning worship service. He wants to include us in His plan, which is to go into all the world. Jesus said, "Go into all the world and preach the Good News to all creation" (Mark 16:15). In the context of

'Basden, 135-7. 
this paper, "all creation" consists of the congregation in which it is our responsibility to minister in providing worship services.

The planning process is unique for a Christian leader because it begins with a realization that God has a plan and purpose for His church and its people. "For I know the plans I have for you, 'declares the Lord,' plans to prosper you and not to harm you, plans to give you hope and future" (Jer 29:11). God also says, "I will instruct you and teach you in the way you should go; I will counsel you and watch over you" (Ps 32:8). To Jeremiah God said, "Before I formed you in the womb I knew you, before you were born I set you apart; I appointed you as a prophet to the nations" (Jer 1:5). In these passages God makes it clear He has a plan for each individual in our congregation.

Unfortunately, some leaders use this biblical assurance as an excuse for not planning. On the other hand, some take the same assurance to do it all by themselves. There is no place for either extreme. God has a plan and wants us to plan to serve Him. Paul makes this point clear by saying, "I planted the seed, Apollos watered it, but God made it grow" (1 Cor 3:6). As worship leaders we must realize our responsibility to determine the actions or the roadway God wants us to take, and then trust Him for the results. Again the Scripture says, "Many are the plans in man's heart, but it is the Lord's purpose that prevails" (Prov 19:21).

\section{God Is the Source to Achieve Plans}

Although the Bible does not give details, there is no doubt that many of these achievements required hours of planning. 
And what more shall I say? I do not have time to tell about Gideon, Barak, Samson, Jephthah, David, Samuel and the prophets, who through faith conquered kingdoms, administered justice, and gained what was promised; who shut the mouths of lions, quenched the fury of the flames, and escaped the edge of the sword; whose weakness was turned to strength; and who became powerful in battle and routed foreign armies. (Heb 11:32-34)

This passage teaches us that the plans were based on faith in God to produce the results. "In his heart a man plans his course, but the Lord determines his steps" (Prov 16:9). Consequently, worship leaders must first acknowledge that God has a plan and prayerfully aspire to it. Once the plans are created and implemented, God must be trusted for the results.

\section{God Has a Purpose}

When worship leaders define the purpose of worship, people are motivated to unite behind a cause. Jesus always invited people to be involved in a cause or purpose, not a job or plan. The responsibility or task was given only after people joined the cause. Jesus began His ministry by saying to the potential disciples, "Come, follow Me . . . and I will make you fishers of men" (Matt 4:19). The Bible is clear in mentioning the purpose for those who want to follow Jesus, and He Himself declares for what purpose this was to be achieved. "Therefore go and make disciples of all nations" (Matt 28:19).

God instructed Nehemiah to tell the people the purpose for rebuilding the wall around the city of Jerusalem. "You see the trouble we are in: Jerusalem lies in ruins, and its gates have been burned with fire. Come, come let us rebuild the wall of Jerusalem, and we will no longer be in disgrace" (Neh 2:17). God also explained His purpose when $\mathrm{He}$ asked Noah to build an ark for his family and the animals (Gen 6:9-22). He answered 
Noah's questions about why to build an ark.

Jesus had a plan to save humankind and follow it without giving up. This is a major reason for His success. Nothing could stop Him. Knowing that the end of His plan/mission was in Jerusalem, and even knowing that the ultimate sacrifice would be required of Him to be there, His face was set "like a flint" (Isa 50:7) toward Jerusalem. Jesus was determined. Whatever the consequences, He would go to Jerusalem and carry out the plan. Knowing where to go, He went there. To save humankind, He prayed for it, planned it, prepared it, promoted it, and the plan's culmination came at the cross when $\mathrm{He}$ inducted the plan of giving His life.

In the same manner, worship leaders should have a purpose to plan worship service improvement and be ready to answer questions from the congregation.

\section{Visualization of the Complete Plan}

Having the whole vision of the plan helps to stimulate action, innovation, and creativity. It helps people to make a strong commitment to the ministry. It also helps to create unity and personal convictions to motivate and justify the involvement of the individual in achieving the goal. A good example for this is when, before the battle with Goliath, David visualized the outcome. He said in 1 Sam 17:45-46 LB:

You come to me with a sword and a spear, but I come to you in the name of the Lord of the armies of heaven and of Israel, the very God whom you have defied. Today the. Lord will conquer you and will kill you and cut off you head; and then I will give the dead bodies of your men to the birds and wild animals, and the whole world will know that there is a God in Israel!

Visualizing the end result before going into battle helped David to plan his attack 
and to determine the actions needed to achieve his plan. He also demonstrated that he knew the purpose of the battle with Goliath: "And Israel will learn that the Lord does not depend on weapons to fulfil His plans" (1 Sam 17:47 LB). Understanding the purpose motivates to action. Visualizing the end result helps to create the plan. Even though David carried out the steps of the plan, he was trusting in the Lord for the results. Again, for the worship leader of the small SDA church, to have all the best equipment, gifts, and resources is not more important than having a good cause, plan, source, purpose, or vision, and moreover, trust in the Lord.

\section{SDA Leadership Advice for Worship Planning}

The above biblical principles can be applied to the context of planning worship. The Bible provides many examples of planning and leaders whom God chose who were willing to make and carry out plans. These can become strong examples for current church leaders. In like manner, it could motivate leaders to connect with biblical principles and practice them in association with advice given by SDA church leadership.

The SDA Church Manual recommends that "the worship of God is the highest, holiest experience possible to humans, and the greatest care should be exercised in planning for this service." The following paragraphs provide ideas and suggestions for meaningful worship service preparation.

1. New forms of worship. A word of encouragement for Adventist ministers is

${ }^{1}$ Seventh-day Adventist Church Manual, 71. 
that they "should not be afraid to experiment with new forms of worship," but it also says that some guidelines should be followed.

2. Share responsibilities. In regard to planning the Sabbath worship service, the Minister's Handbook recommends that church leaders (a) should have a direct responsibility for the worship service, (b) they should share this responsibility with elders and a possible worship committee which will probe new ways to enhance the worship service, and (c) they should have a countdown sheet with all the items and who is responsible for it. ${ }^{2}$

3. Worldly models. Recommendations which follow may help SDA church leaders gain confidence to apply advice from other leaders with regard to the planning, coordination, organization, and preparation of the worship service, to avoid routine as mentioned in the Elder's Handbook:

Successful worship does not just happen. The services must not become mere routine. The worship service involves the coordination of the activities and talents of many people and therefore must be well planned. Radio and television have circled our globe and are available to most of our members. Programs of these mass media are precisely planned and meticulously organized. People are embarrassed and ashamed if the church service is not. ${ }^{3}$

4. Personal spirituality. Planning for worship involves not only the service but also personal planning; the preparation of worship leaders must first of all be spiritual. Their attitude during the worship service is a mere extension of their spiritual preparation

${ }^{1}$ Seventh-day Adventist Minister's Handbook, 145.

${ }^{2}$ Ibid., 147.

${ }^{3}$ Seventh-day Adventist Elder's Handbook, 139. 
for worship. ${ }^{1}$ They need to know God and have a living relationship with Him. Not only will their attitude affect how they do what they do, but how they do what they do will determine how their attitude is perceived by the congregation. Leaders cannot lead people to where they (the leaders) are not or to where they are not going. ${ }^{2}$

5. The role of the Holy Spirit. Some leaders think that planning worship services is the opposite of trusting God. This thinking is similar to that of preachers who believe they do not need to study because they want to be led by the Holy Spirit while preaching. God can lead and direct leaders in their corporate worship planning. They must depend upon His guidance in their planning as well as in the actual ministry for which they are planning. ${ }^{3}$

6. Master plan. Few small SDA churches have a master plan by which they map their course and evaluate their progress. Without a plan for creating worship services, a church weekly takes one step forward and three steps backward toward accomplishing its mission. Without a plan there is nothing toward which to direct the resources God provided to be used for His glory. With a plan, a church has control of its activities and

${ }^{1}$ C. Raymond Holmes and Douglas Kilcher, The Adventist Minister (Berrien Springs, MI: Andrews University Press, 1991), 125.

${ }^{2}$ Ibid.

${ }^{3}$ Kennon L. Callahan, Dynamic Worship: Mission, Grace, Praise, and Power (San Francisco, CA: HarperSanFrancisco, 1994), 143-53. 
resources. A plan allows a church to actively run on the road rather than passively walk on the curbside. ${ }^{1}$

Ellen White points out that "it is essential to labor with order, following an organized plan and definite objective."2 Later she comments: "Well-defined plans should be freely presented to all whom they concern, and it should be ascertained that they are understood. Then require of all those who are at the head of various departments to cooperate in the execution of these plans." White even calls it a sin not to have any goals or purposes: "It is a sin to be heedless, purposeless, and indifferent in any work in which we may engage, but especially in the work of God." ${ }^{\prime 4}$

\section{Aspects of Planning}

The time spent in planning worship can result in rapid improvement when it brings about: (1) brainstorming-developing ideas related to a particular worship service need; (2) selecting, or reducing, a long list of ideas into a shorter, manageable list; (3) alternative actions-which result from brainstorming and offer different ways to achieve the result needed in the worship service; (4) continuity in action-maintaining actions the church is doing to achieve worship improvement; (5) discontinuing action which does not help the

\footnotetext{
'See John C. Maxwell, Success: One Day at a Time (Nashville, TN: Countryman, 2000).

${ }^{2}$ Ellen G. White, MS 24, 1887, Ellen G. White Research Center, Andrews University, Berrien Springs, MI.

${ }^{3}$ Ibid. 178.

${ }^{4}$ Ellen G. White, "Sabbath Reform Needed," Review and Herald, 18 March 1884,
} 
church service achieve its vision and mission; and (6) beginning of action or improvement-things the church is not doing now, or not doing well enough, which would help the worship service achieve its objectives. ${ }^{1}$

Planning corporate worship usually begins with certain assumptions. It involves the gathering of information by assessing the congregation. It may identify and describe possible problems. It allows a consideration of options for solution. It demands making decisions today which will shape the realities of tomorrow. Planning worship is the process by which leaders seek ways to achieve the goals. Planning worship takes time as well as precaution. The leaders must anticipate constantly and think ahead.

1. Respect sequence in action. Step two of the APIE model helps to define what specific improvement the church wants to focus on during a specific period of time. The church plans the worship service based on the information gathered in step one, which helped identify what elements of the worship needs to be improved in order to serve the worshiper better and to accomplish the church's mission and its objectives. Knowing "where we are now" in terms of church worship planning helps to take us "where we want to be" and, moreover, to develop a commitment for improvement in the sense of "ideally where we want to be." When planning the worship-outputs, the church is, in effect, making tomorrow's decision today.

Many church leaders have the tendency to jump from step one, assessing the congregation's needs, directly to step three to implement any improvement in the worship-

'See Howard G. Hendricks, Color Outside the Lines (Nashville, TN: Word Publishing, 1998), 109-16. 
outputs. In doing so, they miss the opportunity to be creative and innovative. Time must be invested to plan and identify alternative actions. Step two provides opportunity for leaders to brainstorm and to suggest unlimited ideas for actions they might consider. Planning is not a time to debate actions or implement suggestions received.

2. Planning ahead of time. In relation to time, "planning can be short-range, intermediate-range, and long-range. Short-range planning includes preparation for the week. Intermediate-range planning involves upcoming annual events. Long-range planning consists of events and goals whose nature and scope require several years for their achievement."

Church leaders should plan their worship programs a year in advance rather than operating on a month-to-month, or even Friday-night basis. Planning an annual calendar helps to avoid conflicting dates and events. Plans may need to be changed, unforeseen circumstances may arise, and new factors may call for various adjustments in the worship program.

3. Benefits of planning. The planning of worship helps churches to think in an anticipatory mode, minimizing the risk of falling into a reactive attitude that may be provoked by any positive or negative behavior from its congregation. Church leaders need to be aware that proactive rather than reactive behaviors lead congregations to the offensive. In order to plan better worship, congregational initiative needs to be exercised.

Furthermore, planning has a powerful motivational impact in the life of the church.

'Kenneth O. Gangel, Team Leadership in Christian Ministry, rev. ed. (Chicago, IL: Moody Press, 1997), 293-98. 
Motivation to accomplish results tends to increase as people are given opportunity and time to participate in the decision affecting those results.

4. Planning goals and objectives. Planning worship is a process of developing goals and objectives with the intention of setting up strategies for reaching these goals and objectives. Webster's dictionary defines the word goal as "the end toward which effort or ambition is directed: aim, purpose." A goal in worship planning, therefore, shows direction. It is something that church leadership should search for.

Setting goals is a vital component for any church that is seeking to be successful in the continuous worship improvement. "Big goals normally excite a church and win congregational support faster than small goals." ${ }^{22}$ Highly motivated people are attracted by great ideas. When a vision is limited, those who have the capacity to catch a broad, exciting vision for ministry are immediately cut off. ${ }^{3}$ Small churches with big goals tend to attract people with great visions to ministry and, therefore, will grow. Small churches and small thinking tend to lose motivated people and, consequently, these churches will disappear.

5. Benefits of planning goals. There are some benefits of planning goals for the worship service. Consider this list: goals give a sense of direction and purpose, give the power to live in the present, promote enthusiasm and strong organizational life, help

\footnotetext{
'Webster's New Collegiate Dictionary (1974), s.v. "Goal."

${ }^{2}$ Don Cousins, Leith Anderson, and Arthur DeKruyter, Mastering Church Management (Portland, OR: Multnomah Press, 1990), 60.

${ }^{3}$ Ibid.
} 
churches operate more effectively, help them to evaluate their progress, force them to plan ahead, give people a clear understanding of what is expected, help to reduce needless conflict and duplication of effort, and take the emphasis off activity and place it on output. ${ }^{1}$ The results of setting goals will be improvement and success in the worship program.

In order for churches to improve their planning process of worship activities, their goals need to be effective. Moreover, they must be written out, positive, measurable and specific, in clear terms, flexible, realistic, reviewed and updated, broken up into manageable units, and owned-in other word create goal ownership. ${ }^{2}$

Planning the worship service takes time and involves consultation. Prov 15:22 (NIV) says: "Plans fail for lack of counsel, but with many advisers they succeed." Many details must be worked out and problems solved as the church prepares and plans for corporate worship.

Seven questions may be raised in order to facilitate the worship planning process. These inquiries need to be repeated every time the leaders and their congregation attempt to plan worship.

1. Who are we? This definition of the congregation's basic identity or dream is the most fundamental step leaders must take in order to present a truthful worship to God.

2. Where are we? Here leaders are reminded that the church's heritage has

'Class notes for "Worship Workshop: Church Leadership Training Program," January 1995.

${ }^{2}$ Gangel, 275-87. 
continuity in history, referring to a past, a present, and a future. This will help us to keep in mind, throughout the worship service, the faith of our fathers and how they worshiped.

3. Where do we want to go? To a large extent, churches have the option of selecting their preferred futures in worship. This will allow people to make decisions whether to stay or to go, bringing the church either to grow or to die. It will also grant the choice of continuous planning and improving or not.

4. How are we going to get there? Ministry programs, congregational involvement, targets, and tactics provide the nuts and bolts of successful worship planning.

5. When will we get there? Worship service plans are not complete until the goals are reached. Good goals are evaluated in terms of timing, quantity, and quality.

6. How much of our resources will we expend? Regarding this point, churches need to use their resources carefully. To improve worship service, however, human and material/financial resources are needed.

7. How will we know we have successfully implemented our plan? An evaluation will complete the planning cycle and kick off a new planning process. ${ }^{1}$

\section{Why Worship Plans Fail}

Many failures attributed to leaders in achieving their goals for improving the worship service are due to either poor planning or a total lack of planning. Worship objectives ought to be specific, measurable, and realistic. Observation of a variety of churches suggests a number of reasons why some worship planning is failing:

\footnotetext{
'Class notes for "Worship Workshop: Church Leadership Training Program," January 1995.
} 
1. Lack of real goals: A goal that does not describe an end state is not a goal. In some worship services it is hard to know where and when the leaders are taking their congregation into a real experience closer to God.

2. Lack of measurable objectives: When objectives are not clearly stated. This assessment can be easily done by observing the church bulletin and compare with what really is happening during the worship service.

3. Failure to anticipate obstacles: Plans should be flexible enough to overcome unanticipated obstacles. For example, one small church had to send the congregation home because the pastor was sick and could not preach.

4. Lack of progress review: Correction provides direction, pace, and reality. Some leaders say that they have been worshiping in that way for fifty years and that there is no interest in reviewing the current process.

5. Lack of commitment: The lack of desire to see a plan through to its completion. Some churches are good starters but not good in conclusions.

6. Failure to revise objectives: This links up with failure to anticipate obstacles and calls again for flexibility in the worship plan.

7. Failure to learn from experience: Feedback should be obtained at every obstacle and trigger the question of what was learned this time.'

Church leaders should dedicate ten minutes after the worship service-perhaps while greeting members at the door-to glean feedback from some members regarding

${ }^{1}$ Class notes for "Program in Public Worship Development," Brasilia, DF, Brazil, July 1994. 
how the day's worship service did impact their lives.

Sometimes church worship plans do not materialize; nevertheless, a leader should not be discouraged. It could be an opportunity to see God working things out in spite of unfulfilled plans, and to discover the areas in need of improvement. For plans to materialize, they should not appear too difficult to undertake, because the church is not naturally attracted to hard work.

\section{Steps in Organizing the Worship Service}

Another important task of worship planning is organization. Exod 8:21 presents some basic principles of organization. Authority and responsibility relationships must be established among the people intending to accomplish the planned goals for the worship service. Organization is necessary in order for the plans to be ready for the next step of implementation. Planning and organizing are distinct functions. "Organizing is people working together to get things done." It helps people to work together in preparing and promoting the created worship program. When nothing is required of worshipers, nothing is received. Furthermore, organizing worship is deciding the pattern of relationships among persons who have a common task or purpose to accomplish.

Several steps help a church leader and the congregation to organize worship.

'Si Kahn, Organizing (Silver Spring, MD: National Association of Social Workers Press, 1991), 5. 


\section{Recruiting Helpers}

Recruiting is an endeavor to obtain the greatest amount of involvement by people in order to accomplish the task of planning worship. Many leaders have trouble recruiting volunteers to be involved in the worship service. In order to be effective, church leaders must be certain that they have the right attitudes in recruiting.

Kenneth Gangel suggests some important points for effective recruiting that can be applied to worship planning.

1. Recognize the need for help. This is the first attitude that must be developed. Some leaders feel they are the only ones in the group capable of doing the work.

2. Recognize that God has given everyone a special gift or ability for building up the body of Christ and celebrate it through worship. Leaders must believe strongly in the principles of gifts as recorded in Eph 4:11-12.

3. Communicate the importance of the task. Failure to communicate the importance of the task and of being involved in corporate worship is a big mistake church leaders make when trying to recruit volunteers.

4. Let the people know that the work cannot be done without them. One of the greatest mistakes leaders make is doing the work in worship that others can do.

5. Let people know how much you appreciate their skills and willingness to use their gifts. If volunteers are expected, let them know that their ability to do the work is believed in. ${ }^{1}$

Church leaders must remember that the worship service is the work of the

'Gangel, 319-32. 
congregation. Ask for their opinions, get their perspectives, listen to their ideas, get them involved, and let them be innovative. Trust the congregation, for they are willing to help and are looking for new challenges. Help them to get excited about being involved in worship. Participants will be happier, and so will the leaders. ${ }^{1}$

As church leaders plan to recruit and involve the greatest number of people in worship, they must remember to always identify which ones could be involved and what they might do. Then responsibilities can be assigned.

\section{Delegating Responsibilities}

Delegating responsibilities is an important activity in the planning and organization of worship. However, there is a lack of trust on the part of some of the congregational leadership to welcome the worshipers to participate in the actions of worship. Delegation is granting to others the right to make their decisions accompanied by responsibility. Delegation also means having other people do part of the work and learning how to identify the work that must be done-devising methods of sharing portions of the work with other people. ${ }^{2}$

In contemporary organizations, decisions are made at the lowest administrative levels. Thus authority and responsibility are delegated as far down as possible. Involvement boosts people's feelings of self-worth and makes them feel that they are

${ }^{1}$ See Roger Fulton, Common Sense Leadership (New York, NY: Barnes \& Noble, 2001), 45.

${ }^{2}$ White, Testimonies to Ministers and Gospel Workers, 302-3. 
indeed a part of the group. ${ }^{1}$ Delegation is the entrusting of a task to the care or management of another. ${ }^{2}$ It does not mean abdication, however. Leaders who delegate do not transfer personal responsibility, walk away, or provide no further leadership.

1. The need for delegation. To experience improvement in worship, leaders should delegate church worship responsibilities more frequently. Some of the principles Gangel advocates in the field of church leadership do very well apply to the worship context. Here are some of his reasons why leaders should consider delegating responsibility:

a. Leaders are not doing the main work that needs to be done because of too many responsibilities.

b. Leaders are missing deadlines.

c. Leaders spend time on trivial tasks that others could do.

d. Leaders have volunteers who, if trained, could handle the job better.

e. Leaders have an imbalance in the workload of their volunteers.

f. Leaders have volunteers who need new worlds to conquer. ${ }^{3}$

The only one who did not need anyone to help do the work was Jesus. Nevertheless, He delegated. Mark's Gospel says, "Jesus . . called to him those he wanted, and they came to him. He appointed twelve, designating them apostles, that they might be with him and that he might send them out to preach and to have authority to

${ }^{1}$ Gangel, 400-1.

${ }^{2}$ Ibid., 392.

${ }^{3}$ Ibid., 393-98. 
drive out demons" (Mark 3:13-15, NIV).

2. Reasons for resistance to delegation. Observation of attitudes in some small churches has suggested why leadership resists delegation: (a) a reluctance to admit limitation, (b) tradition and the desire for prestige and control, (c) a lack of confidence in the people, (d) leaders doubting their own ability to train others to do the work, and (e) ignorance of the benefits of delegation. Consequently, many leaders conduct the worship service by themselves in an act of improvisation.

When delegation is not practiced in worship, everything becomes routine and almost imperceptibly comes to a standstill. If improvement is not made to the very best, if improvement is not assured, if people are not involved, the sad state in which many small churches are today will be maintained. The negative aspect of the failure to delegate is also a consequence of underdeveloped church leadership. Leaders should not forget that God, who has given them leadership ability, has given it also to others.

3. How to delegate. Kenneth Clark offers leaders advice for delegating effectively: (a) Select the jobs to be delegated, and get them organized for turnover, (b) choose the proper person for the job, (c) prepare and motivate the delegates for their assignment, (d) hand over the work and make sure it is fully understood, (e) encourage independence, and (f) maintain supervisory control. ${ }^{1}$ In following this advice, leaders will avoid asking people at the last moment to pray or present the Scripture reading, exposing their sincerity and willingness to be involved.

'Kenneth E. Clark and Mirian B. Clark, Choosing to Lead (Charlotte, NC: Iron Gate, 1994), 143. 
4. Steps in delegation. Carl George and Robert Logan present important steps to be considered by leaders in the process of delegation: (a) Recognize the necessity of delegation, (b) possess the right motives for delegation, (c) determine what can and cannot be delegated, (d) develop job descriptions for those things needing to be delegated, (e) recruit potential people, (f) provide support, encouragement, and training, and (g) avoid reverse delegation.'

5. When not to delegate. Sometimes in specific situations the activities of the worship service cannot be delegated. George and Logan present some situations when delegation is not appropriate: (a) the leader's responsibility is to correct or discipline, (b) major problems have arisen, (c) tasks involve confidential information, and (d) it is necessary to create and maintain morale. ${ }^{2}$ The $S D A$ Elder's Handbook also suggests that "planning includes making certain only authorized persons preach or lead out in the service. Individuals dismissed from church fellowship or ministers dropped from the ministry should not lead out in worship." "In like manner, some elements in the worship service require ordination (i.e., baptism, child dedication, and communion).

In the planning step, delegating or assigning responsibilities is limited to scheduling those responsible for completing each task, and using the commitment of the person to be involved in the worship service elements. It is important to remember that in this step we

'Carl F. George and Robert F. Logan, Leading and Managing Your Church (Grand Rapids, MI: Fleming H. Revell, 1996), 113-25.

${ }^{2}$ Ibid., 118.

${ }^{3}$ Seventh-day Adventist Elder's Handbook, 140. 
are only planning. The assignment of the task in telling the worshiper their responsibilities will take place in the next step of the APIE model of continuous worship improvement.

\section{Prioritization}

The example of Jesus Christ shows us that setting priorities needs to be present in any attempt of improvement in personal life or church service. When He said, "Let the dead bury their own dead" (Matt 8:22), the principle presented is to make sure that nothing distracts us from the real and most important goal. And maybe His most important teaching principle in setting priorities is "Seek first the kingdom of God and His righteousness, and all these things shall be added to you" (Matt 6:33). This principle sums up the entire plan and priority of Jesus. In other words, get your priorities done and everything else will fall into place. In the worship service our priority should be serving God and serving others.

In corporate worship, leaders should take into consideration not their own personal tastes or priorities but serve the congregation as they provide the worship service. Worship leaders must pay special attention to the process of establishing priorities in the delivery of the worship-outputs. Setting goals and setting priorities for the worship service is a continuous process. A continual review of the worship plan must include an ongoing review of goals and, therefore, a continual review of priorities that need to be implemented. Urgent needs should take precedence over less important goals to avoid getting lost on the journey. 


\section{Step Three: Implement the Elements of Worship}

Once plans are in place and tasks are assigned, there is a need for implementation. No matter how well worship plans are formulated, they will be of little value unless they are installed and actuated. Someone or several people must take responsibility for implementing that which is planned. Planning and organization are essential; however, those two elements are insufficient for obtaining the desired results. ${ }^{1}$ The congregation also needs to be involved in the third stage of the APIE model. As the members become involved in assessing, planning, and now implementing the actions of worship, the experience of improvement will become effective for both the church and the individual.

Implementation is an important step because it moves from the stage of what to say, to that of what to do. In the previous stages brainstorming was the main tool, on this level the question is "What do I do?" in the words of the old saying "Actions speak louder than words." Unfortunately, many leaders believe in the myth that the word alone can fulfill most worship needs. True worship, however, happens only when the actions of worship result in concrete acts within people's life and not just words. This may be the reason why some people listen to wonderful preachers and still go home empty. On the other hand, when worship involves individuals as much as possible in "actions" of worship, all go home satisfied. The satisfaction comes from the opportunity they have to be the worshiper and at the same time the deliverers.

Though different churches have different plans, all plans that need to be

\footnotetext{
${ }^{1}$ Ricardo Norton, Syllabus for CHMN 664 Equipping Lay Leaders for Church Growth, Andrews University, Berrien Springs, MI, 1997.
} 
implemented have certain requirements in common. Churches willing to be renewed by implementing improvement in their worship elements are churches that, having lost touch with their own people, create a worship experience that will relate to them in a meaningful way and minister once again to their needs. The process of improvement not only changes and implements a new style, but it changes attitudes. ${ }^{\prime}$ Leaders willing to involve the people begin to realize what John Maxwell advocates: "Improvement is impossible without a change in leadership." ${ }^{.2}$ The whole church, leaders and congregation, begins to experience the difference.

A biblical basis for implementation can be found in Mark 6:7-11 when Jesus called the twelve together and sent them out two by two to preach the gospel. Implementing means putting people in action. True corporate worship happens when church leaders lead the congregation into acts of worship. Implementation is guiding the flow of improvement along the "journey to heaven's road"-leading people, as they worship, toward eternity. Implementation needs to build upon the fact that the church's mission is to produce more and better Christians through its worship service. ${ }^{3}$

Improvement itself is a challenge. Implementing improvement can become a greater challenge. However, the challenge should come with satisfaction because when the church makes decisions to improve its worship service, people draw closer to God. 1998), 21.

'Brian D. McLaren, Reinventing Your Church (Grand Rapids, MI: Zondervan,

${ }^{2}$ John C. Maxwell, The 21 Irrefutable Laws of Leadership (Nashville, TN: Thomas Nelson Publishers, 1998), 87.

${ }^{3}$ McLaren, 28. 
James F. White challenges leaders to rethink their worship services by implementing some characteristics that carry a seeker sensitivity and more cultural relevance in order for the worship experience to become more applicable to all.' Implementation is not applying what is better for one, but what spiritually could be meaningful and relevant to all involved in the worship experience.

Strategy implementation in the APIE model requires action, mobilizing members and leaders to join in the work of worship improvement. This implies personal discipline, commitment, and sacrifice. Implementation is worth the sacrifice because unimplemented strategies serve no purpose. Implementation has the purpose of achieving results. ${ }^{2}$ In order for results to be attained in the worship service, the leader must be sure that the people know how to implement the goals they have set for themselves. They must know what to do and when to do it, and they must be highly motivated in order to do so. As a result, they will experience continuous improvement in their corporate worship, and, in addition, they will taste the results of the improvement in their lives.

There are some actions and recommendations the church should be aware of as the elements of worship are improved and implemented with the involvement of its congregation. They are: (1) Identify and assign the tasks, (2) Train and direct, (3) Motivation is essential, (4) Keep the interest alive, (5) Recommendations for leading in worship, and (6) Seven Cs of a successful worship service.

\footnotetext{
'James F. White, Rethinking the Church (Grand Rapids, MI: Baker Books, 1997), 81-85.

${ }^{2}$ Phillip V. Lewis, Transformational Leadership (Nashville, TN: Broadman \& Holman Publishers, 1996), 159.
} 
Identify and Assign the Tasks

Identify the tasks already decided upon in the worship planning meetings, and assign the responsibilities to the volunteers whose names have already been selected in the worship planning process. Some elements of the worship service may be more complex than others and may require an extra number of people doing the same specific task in order to complete them. Identify the tasks clearly for each individual who is in charge of doing it or performing it. Give them time for preparing and practicing their specific task and remember that effective churches do not put together their worship service by improvisation.

Specific assignments should be distributed to everyone involved in the worship program in order to avoid overlapping responsibilities and to accomplish the goals effectively. People should receive their tasks and the orientation in how to achieve it in a form similar to a job description. No step of any worship service program will materialize unless someone knows and accepts responsibility for each assigned task. This should be considered as every single assigned step is viewed as a sub-objective of the overall purpose of the worship service. Moreover, this action will contribute tremendously to avoid two people showing up for the same task on the same Sabbath.

\section{Train and Direct}

Success in church worship depends on more than just good intentions. Having abilities in other fields does not necessarily qualify an individual for a specific task. Efficiency and improvement in accomplishing church worship tasks demand a reasonable 
amount of specific training and respect for the individual spiritual gift. Without training, the completion of an assigned task could put the quality of the worship service at risk.

Training in worship is essential if improvement is desired. Worship training begins in the home. Worshiping church members come from worshiping homes. Family worship should be strongly encouraged. Regular periods of training in the church are excellent opportunities for improving worship at home. Leaders of the church are the key to this kind of improvement. ${ }^{1}$

In order to pursue improvement through training, mentoring is essential. Church leaders can choose from various ways in which mentoring of the congregation can happen, such as preaching on worship; individual training; group sessions, such as gathering the whole church to fill in the evaluation forms, which gives the mentor a chance to explain and explicit the various points; and imaging through modeling. I have found the following principle helpful in mentoring: accept the people you will lead exactly as they are, and give them an example of what they can become.

Future leaders and the congregation should be trained not only in matters of worship in general, but also in the specific aspects of the SDA theology of worship. In order to create a meaningful worship experience in the local church, leaders should bring every member, through teaching and mentoring, to gain a good understanding of these three subjects in worship: What is the meaning of (1) worship in general; ${ }^{2}(2)$ of SDA

\footnotetext{
'Morey, 38-40.

${ }^{2}$ See above, pp. 10-15.
} 
worship in particular;' and (3) of a genuine encounter with God? $?^{2}$

As worship is prepared, leaders should be aware of the importance of seeking objective results or worship outcomes, as a consequence of the worshiper's genuine encounter with God. Too often, people come out of the worship service fulfilled simply on the emotional level, but without being challenged for a life-changing decision. Church leaders should be trained to ask themselves how the worship service could contribute to bring authentic change and transformation to the worshiper's prayer life for example, or to his personal life, to his relationships, to his spiritual discipline, etc. Leaders should seek to assess those outcomes by means of objective parameters. ${ }^{3}$

When the training and mentoring process is taken seriously and a meaningful worship experience is achieved by the leadership, the church will take ownership of their worship even when the pastor is not present.

When tasks are assigned and people are committed to their completion, leaders should help them to get focused on their responsibilities, training and directing them. This guidance will ultimately benefit the "simple" worshiper, helping him/her to be more focused and motivated in the act of adoration. If we ask someone's help in leading out in any element of the worship service, we should tell them four things: (1) the need for doing it, (2) recommendations on what to do and how to do it, (3) the benefits of doing it, and

'See above, pp. 34-36.

${ }^{2}$ See above, pp. 50-51.

${ }^{3}$ See Appendix I. 
(4) additional information for doing it. This information could be applied to any element of the worship service.

The following example illustrates the application of these four points to the offering announcement. The person asked to give the offering announcement during the worship service is provided with the four categories of information needed:

1. The need for doing it. What is the opportunity, problem, or issue? What is the result? Example: In a worship survey, our worshipers told us that they are very unhappy with the three offering appeals in addition to the children's offering for the church school and the new church windows campaign. Also our records indicate that tithe and offerings have decreased in the last four months. These are indicators that the congregation does not have a clear understanding of purpose and the value of the offering.

2. Recommendations on what to do and how to do it. What action is the church leader recommending be taken to deal with the issue, opportunity, or problem? Example: We need to stress the importance of giving as an act of worship and adoration, training the person in charge of the offering to make that moment meaningful and worshipful.

3. The benefits of doing it. What are the benefits to the volunteer involved if he/she carries out the recommended action? What is the advantage for his/her spiritual life? Example: The more everyone is aware of the importance of the offering as an act of adoration and sacrifice, the more they will be increasing their personal and corporate worship experience in the acts of adoration. Consequently, the offering will become an act of worship and adoration rather than a response to a church budget supplication.

4. Additional information for doing it. What additional information is required in 
order for the person responsible to complete the task? Example: Training and literature can be provided, and be prepared for some reaction. Elements of worship, if not presented in the right way, will not be able to create a meaningful worship experience. As a result we will have dissatisfied worshipers, who will try to find a place where they can really worship without being approached financially four times during the same service. The church loses worshipers and does not fulfill its mission.

Church leaders should be aware that a chain reaction can be created when the worship service does not fulfill its main purpose, which is the worship of God. All actions and reactions of the worshipers need to come from the main reason of being at the church, namely, to worship and serve Him only.

Church leaders need to develop the skill of directing, in the sense of knowing and following up everything that will happen during worship. This involves guiding, supervising, controlling, commanding, pointing out, restraining, and keeping within limits. This type of guidance, on the other hand, does not mean that the direction of a worship program is in the hands of a single person. A good leader, on the contrary, helps the church to supervise itself. Directing has to do with performance, training, motivation, and how these are evaluated and improved. The leader is responsible for the final results of how the worship was delivered, and motivation can become essential for building up better results in the delivery of the worship service.

People need to know what they are expected to do, and be aware of the benefits, both in the personal life and for the church, of being involved in a given activity. They need to know why they are doing what we ask them to do and be aware of all the positive 
or negative aspects of a situation occurring in the area they are helping with. The level of detail to be provided will depend on how motivated the people are to do what they are asked to do; and whether they know how to do it. The more they are motivated to perform the task, the more they know how to do it, and the less we need to tell them.

\section{Motivate}

The word "motivation" comes from the original Latin word which means "moving." Webster defines a motive as an inner drive, impulse, emotion, desire, or intention that causes a person to do something or act in a certain way. ${ }^{1}$

People are motivated to worship for different reasons. When the church sets goals and objectives involving members in worship, those will probably accept these goals as their own. Unfortunately, for many churches, the goals, objectives, and implementation of the elements in the worship service are determined only by the leaders. In such a situation, it takes some time before members conform to the objectives of the church. Wise leaders always develop goals and objectives through assessing needs, planning, and implementing in a democratic process.

Church leaders in small churches will not be successful unless they motivate their followers to succeed. Their hearts need to be touched by motivation. It does not matter how much ability members have to be involved in the worship program; if they are not motivated, their performance will not reflect their potential to improve and achieve their goals. On this matter, John Maxwell indicates that leaders "can't move people to action

\footnotetext{
'Webster's New Word Dictionary (1988), s.v. "Motive."
} 
unless you first move them with emotion. The heart comes before the head."' Leaders should realize that one of their most important functions is to help instill motivation in people's hearts. Consequently, followers become more actively involved in the worship service.

Motivation must have a target. Motivation is always directed toward a specific action, the worship of God. The greater the worshiper's motivation, the stronger the drive to perform an action or achieve the goal of a better corporate worship. It is important to keep in mind that a goal never becomes a reality without the proper level of motivation. To assess, plan, and create worship objectives is not enough. Many people who set goals never come close to accomplishing them. Each worshiper must be highly motivated in order to help the church reach improvement. To be motivated, people need to focus on a specific goal or action as they will participate and be involved in the worship service activities.

History has been made by those who are the most motivated, not necessarily by the most talented. Human beings are always motivated to do something. Theories of motivation fall into two broad categories: external and internal. External motivation is sometimes called extrinsic. This approach claims that what is done is done in order to gain rewards or to avoid punishment. It is induced by an outside force. On the order hand, internal motivation is referred to as intrinsic. This theory describes motivation as coming from within the individual. ${ }^{2}$ This kind of motivation, when applied to corporate

\footnotetext{
'Maxwell, The 21 Irrefutable Laws of Leadership, 101.

${ }^{2}$ Gangel, 223-37.
} 
worship, allows leaders and members to express their skills and talents. They are satisfied because the work is gratifying in and of itself. They bring their satisfaction from private worship to the culmination of happiness in corporate worship.

Several suggestions can be made on how to bring out the best in people without resorting to manipulative tactics. As the small-church leaders implement the worship program and involve their members, these suggestions should be applied: (1) Establish a friendly atmosphere, (2) enjoy people's uniqueness, (3) know a person's capabilities, (4) know how much responsibility a person can take, (5) look for ways of mutual benefit, (6) be honest about your goals, (7) use people as positive illustrations, (8) give a person a reputation to uphold, (9) compliment with credibility, and (10) show people that their work is appreciated. ${ }^{1}$

Motivating people to become involved in worship has no set formula. What motivates one person may or may not motivate others. This is why leaders must know the needs of the people they are leading into worship. Christian leaders must know that there is a difference in the way church members are motivated to do their work from the workers in secular organizations. A Christian is motivated by broader goals and objectives. Many church members could earn double or triple payment working extra hours for certain non-Christian organizations. These members remain within the church, spending hours in worship program preparation, primarily because they are convinced that the church has a unique goal and objective to spread the gospel to every corner of this

\footnotetext{
'Robert Coleman, The Master Plan of Evangelism (Westwood, NJ: Advocate, 1990).
} 
earth. They want to be part of this experience of being involved in all activities of worship and preaching the gospel.

Ellen White points out that "the great motive powers of the soul are faith, hope, and love; and it is to these that Bible study, rightly pursued, appeals." Christian leaders, unlike secular leaders, have a very important and effective motivational tool known as the Bible. Leaders can do several things from a biblical perspective to help members become motivated. They should help members to develop the right perspective of God and His power while understanding that the power of God is an important key to personal motivation. ${ }^{2}$ They should also help them to understand their position before God and to be motivated to worship Him in both a private and corporate way.

\section{Keep the Interest Alive}

Church leaders trying to implement changes in the worship service need to consider how the worshiper behaves when changes are being made. People change and accept changes only when they know what is expected of them, understand the expectation, believe in it, and act on that belief. People a have very short attention span today; they resist routine, and it takes creativity to keep them involved in their activities. Some pastors have experimented with different ways of doing the same thing to keep people interested and involved. George Barna presents examples of some of the contrasts that leaders intentionally use to engage people in worship: (1) the head (preaching) versus

'Ellen G. White, Education (Oakland, CA: Pacific Press, 1903), 192.

${ }^{2}$ See Jer 32:17 and Eph 3:20. 
the heart (music, prayer); (2) order (the service agenda) versus spontaneity (sensitivity to the Holy Spirit); (3) reverence (awe of God) versus intimacy (meditation, confession); (4) transcendence (supernatural experience) versus accessibility (tangibility, insight); (5) security (familiar routines) versus risk (trying new things); (6) joy (gratitude) versus contrition (humility); and (7) expression (singing) versus attentiveness (listening to sermon) ${ }^{1}$

In implementing creativity and contrasting forms of worship, people stay more focused and alert, increasing their ability to remain engaged in the worship experience. Barna suggests that "balancing these matters-comfort and discomfort, the old and the new, the easy and the difficult-is more art than science. But, then, so is worship." The well-known Bible commentator, Matthew Henry, encourages worship leaders to create more and more opportunities for the congregation to be involved in the worship of God: "Let every saint praise him, but specially the congregation of saints; when they come together, let them join in praising God. The more the better; it is the more like heaven."

\section{Recommendations for Leading in Worship}

Since the whole congregation is involved in Christian worship, certain recommendations must be presented in order to encourage participation. Worship leaders should remember that the congregational life of worship is central in all that is done and

'Barna, 96.

${ }^{2}$ Ibid., 97.

${ }^{3}$ Matthew Henry, A Commentary on the Bible (New York, NY: Funk and Wagnalls, n.d.), 3:339. 
said. Segler suggests the following guidelines for leading worship:

1. There should be complete preparation in the details of the service. The leader must know exactly what to do, step by step.

2. Proper mental preparation will lead to poise and a calm self-confidence. To lead others in worship, the leader cannot succumb to personal fears and doubts.

3. The leader should seek personal rapport with the congregation. Leaders should be constantly aware that their own emotions are communicated.

4. A positive attitude is essential in leading others in worship. A confident attitude will inspire confidence on the part of the congregation.

5. The leader should speak in a natural tone of voice. A conversational tone is usually preferred.

6. The worship leader must begin on time and not allow any part of the service to drag on or to consume more than its appropriate amount of time. Worship services normally should be completed within a set period of time.

7. Personal eccentricities and distracting idiosyncrasies of a leader are annoying and become a hindrance to worship. Almost everyone is subject to an occasional unusual facial expression or peculiar body movement. The leader should constantly seek to avoid such distraction.

8. The spirit of a leader is contagious; therefore, a leader of worship should reflect a spirit of optimism, hope, and enthusiasm. Worship is always an occasion for joy and hope.

9. One of the privileges of the worship leader is that of participating in worship 
with the congregation. People will follow a leader who shows genuine interest by participating in all acts of worship.

10. The worship leader should model genuine interest in people. Worship leaders should establish warm, personal relationships. ${ }^{1}$

Leading worship involves more than song leading. It is not just exhorting others to sing; nor is it worshiping God while others watch. Leading worship is both worshiping God and drawing others into worship. ${ }^{2}$ This requires training and control in order to dedicate one's best to God.

\section{Seven Cs of a Successful Worship Service}

The Implementation stage concludes with the old wisdom of Seven Cs of a successful worship service. As the small SDA church seeks to create improvement in the local worship service, the Seven $C$ words (credibility, context, content, clarity, continuity and consistency, channels, and capability of the audience) can create a wide vision of what to do as the church implements improvement in their worship services.

1. Credibility. Successful worship services offer credibility. Corporate worship starts with an atmosphere of belief. A congregation must have confidence in its leaders and a high appreciation for their ministry in order for both of them to join in worship and serve God in a credible way.

2. Context. Successful worship services are sensitive to context. A worship

${ }^{1}$ Segler, 241-2.

${ }^{2}$ Basden, 143 . 
service must respond to the realities of this world. Worship "in context" must provide elements that enhance spirituality, provide true opportunities of involvement and participation, and bring about response in terms of willingness to be transformed. This can happen only if the worship service embraces a given social and cultural environment, and addresses people's needs and ministers to them according to their context.

3. Content. The successful worship service brings content to its message. The message must be meaningful to the worshipers, and it must be compatible with their sensitivity. It must be relevant to the worshiper's situation. The content must be doctrinally pure and relevant to today's world. It is the content of the worship service that determines who is going to attend or not.

4. Clarity. Successful worship services are expressed in clear words. The message must be put in simple terms. Words must mean the same to the worshiper as to the leader. Complex issues must be reduced to examples, themes, slogans, and illustrations that have simplicity and clarity. The farther a message has to travel, the simpler it must be. Clarity in the worship service demonstrates unity in leadership, in content, in doctrine, in mission, and in fellowship. All must speak with one voice.

5. Continuity and consistency. Successful worship services have continuity and consistency. They seek improvement as an unending process. Sharing the gospel and the testimonies must be consistent. Repetitions and continuations exist for the purpose of learning.

6. Channels. Successful worship services share the Good News in different channels. Conventional ways of communicating the gospel should be used, received, and 
respected. However, creating new ones is allowed because different channels have different effects and serve effectively the delivery of the message to different degrees. A congregation associates different values with the many channels of communication available in the worship service.

7. Capability of the audience. Successful worship services take into consideration the capability of the audience. Worship is most effective when it requires little effort on the part of the receivers. This involves factors of availability, habits, reading ability, and prior knowledge. Successful worship comes down to lift people to God, and it must take into account the capability of the audience.

The purpose of the third step was to introduce a number of actions to be taken as the church implements its corporate worship service. However, worship service elements and their implementation are not ends in themselves, but only agents to an end. The end of corporate worship is the actual "giving worth to God" which is realized by means of the worship-outputs. These, in turn, are animated and shaped by programs, goals, and objectives. It is important to evaluate-the fourth step-how effective these worship service elements are in creating meaningful and authentic worship.

\section{Step Four: Evaluate the Results in the Life of the Church}

The last step for consideration in the APIE model for continuous worship improvement is evaluation. Too often, leaders do not take the time to evaluate the progress made in the worship service and its impact in the life of the church. Not doing so means that the church loses the opportunity to recognize, to be thankful for, to reinforce 
and to refocus attitudes and actions in the church service and among the worship team. It is important to invest time in conducting well-planned, well-prepared, and well-executed evaluations.

Evaluations provide us with the opportunity to assess progress toward the goals established in step two, and the implementation of the plans established in step three of the APIE model. Evaluation also provides assessment of the level of improvement achieved in fulfilling the needs of the worshipers as they evaluate themselves in reaching their ultimate goal of pleasing God through their lives.

Church leaders from all types of churches, largest or smallest, and willing to have an effective ministry through worship, will take the time to evaluate their services on an ongoing basis. If they do not do so, they will begin to evaluate their worship services when their congregation starts to dwindle. It is interesting to observe that an increasing number of organizations, such as malls, restaurants, banks, schools, or any other kind of service, are improving their evaluation skills to find out how their customers are reacting. In a similar way, churches should evaluate their worship services with regard to what has been offered to God and to His people.

\section{The Biblical View of Evaluation and Performance}

The Bible presents basic principles of evaluation connected with performance and shows interest in the quality and level of our work performance: "Work hard and cheerfully at whatever you do, as though you were working for the Lord rather than for people" (Col 3:23, NLT). Jesus apparently performed to the best of His abilities, for those 
observing His actions commented that "He has done everything well" (Mark 7:37). He shared the secret for improvement by saying, "You shall know the truth, and the truth shall make you free" (John 8:32); "I am the way, the truth, and life. No one comes to the Father except through Me" (John 14:6); "and those who worship Him must worship in spirit and truth" (John 4:24). When we seek to find truth, we are already on our way towards improvement.

Jesus constantly evaluated His disciples with regard to their commitment to His cause. He did accomplish the task Himself when the time came to decide for being committed to excellence. He did this by asking questions, and when He was not satisfied with the answers He found that more teaching was needed. Jesus said it is better to be hot as fire or cold as ice, because if you are lukewarm I will spit you out (see Rev 3:15, 16). He wants us to be committed to excellence. Referring to Jesus' commitment to excellence, Laurie Jones is right in pointing out that "a leader who is not passionately committed to the cause will not draw much commitment from others. The world will make way for someone who knows what he or she wants, because there is not much competition when it comes to passionate commitment." When a church becomes committed to improvement, evaluation can take it from the stage of indifference to that of excellence.

Evaluations help us to see things from different points of view and teach us not to perceive only one way of doing things in our worship. One biblical illustration of this

'Laurie Beth Jones, Jesus, CEO: Using Ancient Wisdom for Visionary Leadership (New York, NY: Hyperion, 1995), 51. 
principle happened when Jesus raised Lazarus. Lazarus was considered dead, but Jesus had a different view. He said, "Our friend Lazarus sleeps" (John 11:11). Through evaluation church leaders also can see that the church worship is dead; or we can just believe that worship is sleeping and needs to be awakened. Our church services need to be given a different look through evaluation so that worship can improve and be given new life, so that all will come to praise Him.

Sometimes church leaders avoid evaluation because it might demonstrate the need for change in their "correct" way of worship. Jesus had a different approach with those who see only one side of the coin and always want to have the last word. He said, "If anyone desires to be first, he shall be last of all and servant of all" (Mark 9:35). Some churches have been doing the same things in worship for over fifty years; people no longer attend their services, but they still believe they are doing all right. Jesus saw things differently, it could have been the first or the last. Evaluation as well helps us to see things beyond the current perception. It allows us to see things that could be done and should be done, and helps us, consequently, to work at making worship service improvement a reality for the church and the congregation. As a final result, leaders and congregation will both be worshiping and serving God as well as serving His people, because the evaluation process increases the sense of service.

People involved in corporate worship should be committed to a high level of quality of performance, and always be looking for improvement. The true worshiper's goal is high performance with a positive and cheerful attitude toward the task being performed. Some leaders mistakenly interpret the word "performance" as "show" or 
"artistic event." This is, however, in contradiction with the biblical perspective, which understands performance in terms of excellence, quality, and thus encourages us to perform to our best because God deserves only the best.

Effective worship services face the reality that part of the worship service is performance. Even the service in a small church is a performance. Charles Arn agrees that "a considerable amount of the difference between large or growing churches and small or declining churches is simply the quality of the performance." Consequently, an important part of evaluating the worship service should be given to the following question, "How was the performance?"

It is God's desire that we all perform well and that the worship community and its leaders strive for high performance. When properly developed and maintained, an evaluation which leads to a better performance can be one of the best improvement tools for achieving and maintaining high performance. Churches do not do well with quality performance for their worship service because they are just not determined enough.

Evaluation helps the quality of the worship improvement. However, quality improvement is a process, not a program, and it can take a long time for it to become a normal part of the church's life. What causes quality is prevention, and what causes prevention is continuous evaluation.

Jesus evaluated individuals not by their goodness but for living by what was required. Therefore, quality in the worship service has to be defined as conformity to

'Charles Arn, How to Start a New Service: Your Church Can Reach New People (Grand Rapids, MI: Baker Books, 1997), 211. 
requirements, not as goodness. People appreciate when churches make and evaluate their requirements according to principles taken from the Bible, not from personal taste or traditions.

Many churches, when evaluating their worship services, face disillusion because of plans not realized, ideas that did not work out; then they try to measure themselves against other churches' formulas of success. It is good to remember that churches became successful by trying new ideas that were too radical to be popular. As they did evaluations, they also passed through pain, tears, endurance, mistakes, and prayer. For them, we must remember, success was a risk, an untried dream, not somebody else's formula for success.' The book of Hebrews did not say to consider the big churches and its leaders and imitate their hair styles, speech patterns, gestures, and their worship style. The Bible says, "Imitate their faith" (Heb 13:7).

\section{The Evaluation Process}

Evaluation is a continuous process that never stops. Continuous worship improvement in the evaluation step requires periodic consideration, correction, and review to see if progress is being made in the right direction. Evaluation is also necessary to determine whether or not the worship goals are being reached. Leaders will not know whether they have reached their goal if they do not know their destination. Where goals have been started clearly and completely, the evaluation process can be plainly established by comparing the two. The process of evaluation gives the ability of control. Any

'McLaren, 114. 
deviation from the goals that have been set should show up if the evaluation is structured properly. ${ }^{\prime}$

The evaluation process covers three basic areas: the personnel, the project, and the material resources. ${ }^{2}$ When evaluating any of these three, a basic question needs to be asked, "How are we doing?" Howard Hendricks suggests that leaders should be continuously asking these four questions of maintenance in the evaluation process as they lead the congregation: (1) What are my strengths? (2) What are my weaknesses? (3) What needs to be changed? and (4) How do I plan to do it? As leaders work in the process of worship evaluation and self-evaluation, personal confidence builds and corporate tranquility is achieved in the church setting. ${ }^{3}$

The evaluation of worship services can contribute to the success of a present endeavor only if it is communicated in time. Effective leaders know that an ongoing evaluation process stimulates progress, and they want to know how the congregation responds to church worship and how the service affects their lives. Defeat or success in any given worship service depends to a great extent on the correct application of the evaluation. Therefore, church leaders in small churches must develop this skill well and understand the importance of early and ongoing evaluation. When the evaluation is not done on a regular basis, people come to understand that the church does not really care about the talents available to improve worship.

'Gangel, 381-3.

${ }^{2}$ Ibid., 376-78.

${ }^{3}$ Hendricks, 77 . 
Evaluate the Delivery of the Worship

Leaders need to review the order of the worship service to find out the extent to which it may be growing meaningless and need change; they also need to determine whether the elements of worship are connecting the people with God. During his research done in churches in the United States, George Barna found that "highly effective churches excel in worship because they take a no-holds-barred approach to connecting people to God. A church that does not consistently and wholeheartedly worship God is a spiritually anemic church. Highly effective churches have discovered the antidote to spiritual anemia: genuine, dynamic churchwide worship." In this process, one must be careful not to make changes so often as to confuse the congregation.

Many church leaders who do not evaluate worship services miss the valuable learning experience of improving corporate worship for the glory of God. Worship leaders should find some time every week to evaluate the service. Paul Basden recommends that church leaders evaluate their worship service with questions like these:

1. Were the needed facilities and equipment ready?

2. Were the worship leaders fully notified and prepared?

3. Did key lay leaders make any significant comments about the service?

4. Did each element of worship meet its goal?

5. Did the people of God actively participate in worship?

6. Did the service have an identifiable flow and direction?

7. Were God's transcendence and immanence portrayed?

'Barna, 111. 
8. Did people leave the service aware of God's love, grace, and power?

9. Did people leave knowing that their sins were forgiven?

10. Did people encounter God in a life-changing way? ${ }^{1}$

\section{Guidelines for Evaluating Worship}

No matter the size of a church or the style of its worship service, all need evaluation. Evaluation is necessary to determine the authenticity of the worship service experience and how accurately it speaks to the needs and expectations of the congregation. Evaluation helps to avoid improvisation and meaningless worship services.

One aspect that needs to be approached through evaluation is whether the content of the worship service corresponds to the beliefs of the Bible. If the fact of worship is a divine-human encounter in which the God of creation works in our personal lives, then we need to provide this encounter in our worship. Robert Webber suggests taking a recent bulletin of a worship service and evaluating its content according to the following questions:

1. In what specific ways was the triune nature of God expressed in the service?

2. Was the story of God's work in history adequately expressed? Was the Good News aspect expressed? Was the relationship between heaven and earth expressed?

3. How did this service help the worshipers identify their dislocation? How did worship relocate the worshiper in God? Did the worship plan interface with the needs of people present?

${ }^{1}$ Basden, 145. 
4. Where did this worship create the feelings of awe and wonder in the worshiper?

5. Was the worship a program? A narrative?

6. In this worship, where were the following experienced: Intention? Imagination? The use of the body expression?

These questions help the church leadership set the context to evaluate not only the worship service or the commitment of the leader, but also to plan worship. ${ }^{2}$ These questions also take us to other primary questions that should be raised when we evaluate the worship service: Is it theologically sound? Is it engaging the congregation in a genuine encounter with God? Worship without an encounter will be just a presentation.

Church leaders involved in planning and evaluating the delivery of worship need to reflect honestly on the design and content of the worship service. Preparation to lead a worship service requires commitment for evaluation. The suggested "Worship Evaluation for Leaders" ${ }^{3}$ could be used as a continuous evaluation tool in the essential and important endeavor of developing a better encounter with God for the congregation.

Another form of evaluation is that of selecting a group of persons to take part in a "Worship Service Evaluation." This survey can help evaluate the present worship as well as supply the leadership with information for new ways of improvement and new forms of 1998), 48.

${ }^{2}$ Ibid., 49.

${ }^{3}$ See Appendix G.

${ }^{4}$ See Appendix $\mathrm{H}$. 
worship. To invite the entire congregation to evaluate the worship service through written questionnaires can be one more idea to use as a fellowship activity after potluck time. The same result can be achieved through a longer form of evaluation including all the separate elements of worship, namely, the survey "Your Personal Evaluation of the Worship Service in Our Church."1

Dialogue with the congregation is another approach for evaluation. This could be done after a potluck and the pastor should lead the dialogue. While some may use such a time for personal complaints, the reality is that most will view it as an opportunity for honest reflection on how to improve their worship to God. At the same time, the pastor and leaders need to be prepared to deal with any and all suggestions, not necessarily on that same day but during the following weeks. Pastors should be prepared to hear all kinds of positive and strange ideas; however, they should be careful not to close the door of communication. When facing non-biblical ideas, take the challenge as an opportunity to preach and teach Christian worship. When receiving positive ideas, incorporate them into the worship service as soon as possible.

Evaluating the results of worship in the church's life can open up a two-way avenue for the improvement of worship. One way is using the opportunity to get closer to one another, both leaders and congregation; the other way is to make a wise use of all the information received during the evaluation process.

'See Appendix B. 


\section{Avoid Reasons for Failure}

Many churches avoid evaluation because they are afraid of finding out about the negatives sides of the worship service instead of focusing on the positive aspects delivered throughout the service. Some churches fail, not by doing anything wrong, but in not looking for their weaknesses. This can become an obstacle for the improvement of worship. It is not possible to improve worship without knowing what to improve and where we failed. John Maxwell has observed a number of motives for failure in leadership which could be applied to our worship leadership. The ten reasons leaders fail are: (1) poor people skills, (2) a negative attitude, (3) a bad fit with the group or activity, (4) a lack of focus, (5) a lack of commitment, (6) an unwillingness to change, (7) shortmindedness, (8) relying on talent alone, (9) poor information, (10) no goals. ${ }^{1}$

Churches which are willing to improve and take the evaluation process seriously, churches which are not afraid to face both the good doings and the failures, are churches that can take the weakness that weakens them and transform it into strengths. There is no limit to how far these churches can go, because they are in God's hand.

After experiencing any mistake in conducting worship, after finding out that some experiences did not work well, or after analyzing how these affected the church's life, the leader should be humble to trust in the Lord and never give up. Evaluation teaches lessons from bad experiences and carries us into good experiences. John Maxwell points out eight questions to ask that help leaders to pass safely from a bad to a good experience:

'John C. Maxwell, Failing Forward: Turning Mistakes into Stepping Stones for Success (Nashville, TN: Thomas Nelson, 2000), 155-62. 
(1) What caused the failure: the situation, someone else, or self? (2) Was what happened truly a failure, or did I just fall short? (3) What successes are contained in the failure? (4) What can I learn from what happened? (5) Am I grateful for the experience? (6) How can I turn this into a success? (7) Who can help me with this issue? (8) Where do I go from here? ${ }^{1}$ It is essential to remember that nobody can keep the worship service down unless the decision is made not to rise again, because Christian leaders do not quit when they stumble, they press on for victory in Jesus Christ. ${ }^{2}$

Each aspect in the evaluation step, be it positive or negative, contributes to understanding and to creating additional information to accomplish effectiveness in the worship experience. Often the congregation experiences a new awareness about worship after participating in a survey. The church realizes that when we do things to honor God there is always some good that comes out of it. No evaluation is complete without experiencing the results, i.e., the impact on the congregation. After all, "we know that in all things God works for the good of those who love him" (Rom 8:28).

Worship performance evaluation and its impact on the life of the church is one of the most important steps of the APIE model. The current worship service, as well as those to come, needs improvement now. Many do believe that evaluation is an instrument that simply looks back to the past. While evaluation indeed does look back to the past, it also looks to the future because it carries the beginning of the process of assessment. Evaluation just takes us a step further in the direction of improvement.

'Ibid., 148.

${ }^{2}$ Jones, 125. 
The fourth step of the APIE comes to the conclusion that the development of the evaluation process in the church should be conducted as a learning experience that is a two-way avenue, that is, to improve the performance of both the worship service elements and the congregation in general (i.e., church leaders and members). As the church leadership conducts evaluations, it should communicate trust, grant freedom of expression, turn mistakes into positive learning experiences, and provide recognition for all involved as a family in the worship of God.

Evaluation is the final step, and in a sense the first step, in a living and learning cycle called APIE that creates a circle of protection which safeguards continuous improvement of the corporate worship service. Thus, the evaluation process takes us back to the beginning of the APIE model, but now with greater capacity for improving what we most want to see happen week by week in our worship services-Jesus being lifted high. 


\section{CHAPTER 5}

\section{THE INTEGRATION OF APIE WITH CORPORATE WORSHIP ELEMENTS}

The previous chapter looked at the APIE model as a tool for worship service improvement and presented several viewpoints on how to assess, plan, implement, and evaluate the church worship experience in the small SDA church. This chapter presents practical suggestions for integrating and applying the APIE model with eight elements of worship, as suggested in the SDA Church Manual. ${ }^{1}$ The eight elements are music, prayer, Scripture reading, preaching, offering, children/youth involvement, testimony, and benediction. Over time these have become non-negotiable elements for corporate worship, and should continue to be at the forefront of any corporate worship planning. The APIE model builds upon these principles; it never suggests abandoning them.

While these elements are valuable, non-negotiable, and need to remain in the forefront, the manner in which they are presented and the amount of input the smallchurch congregation is given in their use, must be improved. Small SDA churches may be small, but the quality of worship should never be less. They must be dedicated,

'See Seventh-day Adventist Church Manual, 88. 
committed, and motivated to improve the worship service, delivering it in the best way possible.

It is hoped that the challenge presented by the APIE model will motivate church leaders to devote more time to planning and improving the worship service. The need for this model is great because, in reality, many lay church leaders have little time to spend in planning the worship service. In the small SDA church the work must be shared and more attention given to the quality of the worship service elements. Satisfied that there is a service planned and offered each week, people usually place little emphasis on the quality of the worship experience being presented. Much of the time the lay leadership in the small SDA church is overwhelmed by the demands on their time and the enormity of the task at hand. The APIE model, coupled with more of the congregation sharing in the planning responsibilities, can help overcome many of these obstacles.

In some churches little variety is offered in the format of the worship service. Prayers are done purposelessly and repetitively. The music selected is unplanned. There is little joy or vitality in the offering being made to the Lord. There is no central theme, no continuity, and very little enthusiasm. The Spirit is often lacking. For what do we really have if we have all the truth but none of the Spirit? The worship end-product may be doctrinally sound and well understood; however, if presented poorly, it will not inspire the worshiper or lift them before God. The purpose of worship should be to bring every participant closer to God. Let us move forward and explore some different ways to accomplish this goal. 


\section{The Language and Power of Music}

Music speaks a language of its own. Music is a divine language emitting a power we can barely understand. Music is the medium chosen by the angels for their heavenly worship of God. Music carries such power to move the mortal soul that David chose to speak through music in his psalms. Striving for worship improvement, "music should have beauty, pathos, and power."

From the Old Testament to the New Testament, the Scriptures have encouraged Christians to "sing psalms, hymns, and spiritual songs with gratitude in your hearts to God" (Col 3:16). We see time and again that God's people incorporate song into the worship service. Music has always been important to worship. The psalmist wrote, "It is good to praise the Lord and make music to your name, O Most High" (Ps 92:1). In like manner, the apostle Paul encouraged the earlier Christians to "sing and make music in your heart to the Lord" (Eph 5:19). There can be no doubt that God holds in highest regard the power of music to create and improve the magnitude of the corporate worship experience.

Although it is not uncommon for the small SDA church to neglect time for music in worship, overall the church has come to value music as one of its most central and powerful worship elements. Sally Morgenthaler points out that "aside from the Spirit of God, music is the most central and powerful element in a worship service. It has an incredible, matchless capacity to open the human heart to God, accessing the soul more quickly, deeply, and permanently than any other art form or human speech (yes, that

'White, Testimonies for the Church, 4:71. 
includes the message!)." Music has the ability to touch the mortal soul more quickly than any other teaching or worship medium.

Church leaders should become aware of the importance of using the language and power of music in worship. Music is a worship element that can span generations, overcome language barriers and bridge prejudices. The impact and emotions of music can play a vital role in adjusting the attitude of the worshipers. More worshipers learn to develop their esteem of God from music than from sermons.

Not realizing the power of music, many churches use it as a background for conversation or as a "bell-ring" to announce the beginning of worship. It is not uncommon to hear people say, "Sing some songs to make people walk into the church," or "Let's sing a couple of hymns while we prepare the platform." Often music is a coverup during the transitional moments of worship. Worship music is able to elevate the quality of the participant's experience only when it has no other end than to glorify God and rejuvenate the spirit.

\section{Worship Music in the World But Not of the World}

A difficult issue, sure to arise, is the relationship of church worship music to the modern-day culture. Inevitably, the church's worship experience is affected by the culture in which it exists, especially when it comes to music. Is this unavoidable? Should it be? Shouldn't the church transform culture and not the other way around? Why do the church's people feel the need to bring guitars and drums into the church? Why are the

'Morgenthaler, 211. 
tried and true classics not enough? These are unavoidable questions in an age where the secularizing forces of culture are very pervasive and powerful. These are questions that can divide a church. Handled incorrectly, they can become Satan's tools.

A simple answer to these questions is that the church should not, and need not, be apologetic for its traditional stand toward Christian worship music. Worship music should be transforming and by its nature different from that offered by the modern culture. It must not give in to cultural pressures and should not change simply because change is easier than resistance. Indeed, the church is a radical, counter-cultural entity, and should always strive to be a culture-transforming entity. The church calls people into a new world when it calls people to a new way of life in Christ. That new world should include culturally different ways of worshiping, singing, and seeing all of life.

Having said that, we must also make some other observations about the relationship of the church to the world. These three observations are not meant to counter the unequivocal call of the gospel to transform the world; they are meant to deepen the understanding of the relationship between the church and the world.

1. Although we seek to transform the worshiper through the worship experience, worship music is in the world, just as our members are in the world. SDA leaders should be sensitive to ways in which the dichotomy between the church and the music of the world can be over-emphasized. Indeed, the questions posed above assume a clear demarcation, but the line between the church and the world is not neat and clean.

As SDA church members, we take creation seriously and recognize that all the 
world belongs to God. We hold Him in the highest esteem. Not only moral laws, but also musical laws, artistic laws, and dietary laws have been created by God for all people to obey and benefit from. All laws were created for the benefit of man.

The fact is that when Christian worshipers apply these laws, while exercising creativity in worship (i.e., in art, in preaching, in this situation, in music), they are doing so in the world (e.g., John 15:19; 2 Cor 10:3). There is no way around it since we live in the world. It is only natural that our ways of creating music will be influenced by the broader forces of the world in which we find ourselves. We do not create music in a vacuum. All music, including the music used for worship, is created within multiple contexts, because composers, instrument players, and singers live in multiple communities: religious, economic, sociological, political, cultural, familial, geographic, and technological. Again, music is not created in a vacuum.

The point is that although the reverence of the worship experience must be preserved, the church exists in the world, and each Christian's musical preference, to a greater or lesser degree, will be influenced by that world. Where possible, we must seek to find a middle ground where all are uplifted, and all can benefit from the music used in the worship experience. This task presents, without a doubt, a delicate balancing act. Although diversity must be tolerated, the sanctity of the worship experience must be preserved.

2. Worship music contexts are always changing. The questions posed, at the beginning of the preceding paragraph, assume that history is static and that musical contexts are set in stone. But history is not a painting on a wall, where time has been 
suspended. It is a drama where things continue to ebb and flow, to move and develop. Consider the contrast between the use of guitars and the use of the organ in worship services. Currently, as opposed to fifty years ago, the musical equation for most worshipers is not as simple as "Bach equals church" and "guitars and drums equals the seventies counterculture." For the present generation, "Bach equals the symphony and the stuffy, upper-middle-class culture," while "guitars and drums equals a musical experience that touches and moves the soul." One generation recognizes Bach as reverent and holy, while to the other generation, Bach is cold and unmoving.

Have things really changed? During Old Testament times, the Christian message was delivered using music made by the instruments of that day. In Bach's time, the same was true. In the same manner, guitars and drums are merely the instruments of this day. The over-simplified equation "guitars and drums equals seventies counterculture" has long broken down. Following a long tradition in church music history, modern-day Christian artists have attached Christian lyrics to musical forms derived from today's world. For many people, especially those who are younger, this music may have a stronger ability to transform their Christian worship experience than the organ.

Musical context, and therefore the meanings people attach to a particular kind of music, is always changing.

3. What does all of this mean for improvement and integration of the worship elements? It is a call for balance, a call for tolerance of each other's preferences. We must sing both the old and the new. We must love the traditional, and if necessary, heartily embrace change. Let us examine the need for both of these aspects. 
First, the church must continue to sing its traditional songs and sing them with power and passion. The church must be allowed to sing these without apology. Even though the surrounding non-Christian culture may not appreciate the musical form of the church's songs, the church must sing those older songs with fervor, for they helped define the church's story. Not to sing them is to deny what the church was and is.

Toward this end, it is important to remember that the church's most powerful songs have always been those songs rising from its own experience, and born out of its tears. Every tradition (i.e., African-American, Brazilian, North-American, Latin, European, etc.) has songs and sounds that are distinctively its own. Some have taken on a unique power through suffering. It is important for the church community to have these traditional, vibrant songs. Young and old must strive to find the rich beauty inherent in these songs.

Second, the church must not fear those inevitable changes in musical expression and, in fact, must embrace those changes. As we know, we live in the world. Musical sounds reflecting the culture in which we live are part of the air we breathe, especially in an electronic age where music can be transported everywhere we go.

Adventist worshipers, who embrace the world in which they live, cannot help but sing and create music that reflects the musical sounds and forms around them. But, they must exercise caution as they create new songs carefully, making sure they unite the worshiper with God. They must be vigilant that the musical forms they use and the messages that are created are indeed compatible, not contradictory. At all times they must 
show respect and tolerance for the forms of the past, and must create and use new songs gradually.

Oftentimes, church members have introduced musical changes radically, instead of gradually. There is no excuse for imposing radical, rapid change that upsets the balance of the church and the worship experience. Such is folly, as it does not build the kind of unity and improvement that is our goal. It is also pastorally foolish. Worship leaders should remember that people come before musical, or any other, agendas. Worship leaders must be sensitive to the congregation they serve and introduce any kind of change gradually. Large doses of wisdom, patience, and love go a long way to change potential worship wars into worship adventures. Let us always remember whom we serve, and the reason for change.

\section{Reasons for Improving Music in Worship}

1. The role of music in worship. Since the beginning of time, as we know it, music has been one of the primary means of praising God. In and of itself, it is an act of prayer. It has an important purpose, that of teaching biblical truths to the people of God. It serves as a confession of faith, and it provides worshipers with a genuine means to actively participate in worship.

2. Music has the power to touch human emotions. In some ways, nothing in life can arouse such powerful human emotions as music. The language of music can speak to the places of the heart that preaching cannot. If not for the power of music, worship 
might become a repetitive, rationalistic experience. Music in worship is the highway that rapidly transports human feelings to God.

3. Music is very closely connected to the memory. Man can more often remember what has been sung than what has been said. Hours after the sermon is finished, the closing hymn will quietly repeat itself in the recesses of the mind. Music is a divine medium reaching old and young, alike. Since memory and music are so closely linked, church leaders should use music more often to teach the message. Music in worship should always have a purpose and be connected with some teaching or message, whether "Jesus Loves the Little Children," or "Shine Jesus Shine, " or "Amazing Grace."

\section{Practical Suggestions for Music Improvement}

In many SDA churches there has been a decline in the amount of time spent worshiping God through music. Some use music only as a call to worship. In some small churches there may not be a piano or a pianist. Despite these handicaps, the SDA church leadership must strive to learn different ways to improve worship by incorporating music. Although not overtly expressed, even the SDA Church Manual suggests that a "special music or a devotional hymn is appropriate immediately before the sermon."1

1. Worship music should be cheerful, yet solemn. "Those who make singing a part of divine worship should select hymns with music appropriate to the occasion, not funeral notes, but cheerful yet solemn melodies. The voice can and should be modulated,

${ }^{1}$ Seventh-day Adventist Church Manual, 87. 
softened, and subdued." Ps 66:1 tells us that our "noises" to the Lord should be "joyful."

2. Practice of congregational singing. Worship leaders should organize a group

of the best singers to lead congregational singing. Ellen White says that

another matter which should receive attention, both at our camp-meetings and elsewhere, is that of singing. A minister should not give out hymns to be sung, until it has first been ascertained that they are familiar to those who sing. A proper person should be appointed to take charge of this exercise, and it should be his duty to see that such hymns are selected as can be sung with the spirit and with the understanding also. Singing is a part of the worship of God, but in the bungling manner in which it is often conducted, it is no credit to the truth, and no honor to God. There should be system and order in this as well as every other part of the Lord's work. Organize a company of the best singers, whose voices can lead the congregation, and then let all who will, unite with them. Those who sing should make an effort to sing in harmony; they should devote some time to practice, that they may employ this talent to the glory of God. ${ }^{2}$

3. Singing is as much an act of worship as is prayer. Ellen G. White stresses that "the proper training of the voice is an important feature in education and should not be neglected. Singing, as a part of religious service, is as much an act of worship as is prayer. The heart must feel the spirit of the song to give it right expression." ${ }^{3}$ We are told that even the angels sing glory to God on high.

4. Use of instruments as a support for music in worship. Worship leaders should use instrumental music as a worship aid. Once again, Ellen G. White counsels that "music

'Ellen G. White, "The Schools of the Prophets," The Signs of the Times, 22 June $1882,277-8$.

${ }^{2}$ Ellen G. White, "Co-Operation with Ministers," Review and Herald, 24 July $1883,466$.

${ }^{3}$ Ellen G. White, Patriarchs and Prophets (Washington, DC: Review and Herald, 1958), 594. 
can be a great power for good; yet we do not make the most of this branch of worship. The singing is generally done from impulse or to meet special cases, and at other times those who sing are left to blunder along, and the music loses its proper effect upon the minds of those present. Music should have beauty, pathos, and power. Let the voices be lifted in songs of praise and devotion. Call to your aid, if practicable, instrumental music, and let the glorious harmony ascend to God, an acceptable offering." "Glorious harmony" is the key word, signifying that the music should be of the highest quality. That by its nature, if performed correctly, it will transform God's people and bring them to the foot of His throne.

Ellen G. White expressed her amazement when she realized that the guitar could be used to provide instrumental music for worship. She commented: "Here a plan quite common in Sweden, but new to us, was adopted to supply the lack of an organ. A lady who occupied a room adjoining the meeting-hall, and who had charge of the building, was a skillful player on the guitar, and possessed a sweet, musical voice; at public worship she was accustomed to supply the place of both choir and instrument. At our request she played and sang at the opening of our meetings."

5. Although music is important it is not for display. Worship music should never foster pride or ambition. Worship music should be performed solely for the glory of God. Ellen G. White again has proper advice about this matter and states that "musical

'White, Evangelism, 505.

${ }^{2}$ Ellen G. White, The Historical Sketches of the Foreign Missions of the SeventhDay Adventists (Basle: Imprimerie Polyglotte, 1886), 194. 
entertainments which, if conducted properly, will do no harm, are often a source of evil. Musical talent too often fosters pride and ambition for display, and singers have but little thought of the worship of God."1 Music performed within the walls of our churches, although joyous and uplifting, must remain reverent.

6. Accomplishments should not take the place of God in worship. Another caution that churches must heed is to not allow anything, even the best of music, to take the place of God in worship. One more counsel from Ellen White states that "when professing Christians reach the high standard which it is their privilege to reach, the simplicity of Christ will be maintained in all their worship. Forms and ceremonies and musical accomplishments are not the strength of the church. Yet these things have taken the place God should have, even as they did in the worship of the Jews." We must remain vigilant to keep the balance between all elements of worship. Music should transform the worship experience, bringing us closer to, but not distracting us from God.

7. Concerns when choosing music. Music should be an expression of worship in every aspect of the service. This means that music should express adoration, thanksgiving, confession, testimony, proclamation, and dedication. In order for music to express a meaningful worship experience, leaders must choose music with a specific intention and purpose in mind, music that brings the congregation into closer contact with 422.

'Ellen G. White, The Voice in Speech and Song (Boise, ID: Pacific Press, 1988),

${ }^{2}$ White, Evangelism, 512 . 
God, with themselves, and with the community. The lyrics at all times should be doctrinally balanced and add meaning to the congregant's worship experience.

8. Provide variation in music. Many churches suffer from a dry, uninteresting worship. They lack the willingness to try doing things in a different way. Some leaders believe that the SDA church itself advises resisting new initiatives, especially when it comes to music. The SDA Minister's Handbook provides some simple suggestions which our church leadership would do well to follow. They are:

a. Have congregational singing during the intermission between Sabbath school and church service, and include at least one new song.

b. Feature Scripture songs instead of hymns from the hymnal.

c. Have youth choruses.

d. Rather than singing all the verses of a hymn, read a verse or every other verse to focus attention on the hymn's meaning.

e. Divide the church into groups and try some of the canons (rounds).

f. If there is no choir, let the congregation sing the introit and responses.

g. Conclude a sermon by inviting the congregation to stand, join hands, and sing as a symbol of commitment and unity.

h. Whenever a hymn is used in worship, note the date in your hymnal so you do not repeat some too often and use others too seldom.

i. Find other ways in your culture of incorporating acceptable traditional instruments of music.'

${ }^{1}$ Seventh-day Adventist Minister's Handbook, 150. 
Finally, when choosing music for use in the church, we must be careful not to choose music that cancels out the message of the words. One of the most needful gifts in the church is the gift of discernment. In his letter to the church in Philippi, the apostle Paul said, "This is my prayer: that your love may abound more and more in knowledge and depth of insight, so that you may be able to discern what is best and may be pure and blameless until the day of Christ" (Phil 1:9-10 NIV). The Amplified Version reads, "That you may surely learn to sense what is vital ... recognizing the highest and the best, and distinguishing the moral differences."

This is fundamental to living the Christian life in the fullness that God has provided and to making the choices and decisions that will please Him. It is especially true if we are going to choose the music that most glorifies Him, music that best interprets who He is, music that helps to improve the relationship between the worshipers and their Creator.

\section{The Power of Prayer in Corporate Worship}

Much instruction was given by Jesus on the importance of prayer in corporate worship and its integration with the other elements of the worship service. He speaks strongly concerning the power of individual prayer, and provides severe warnings against pretentious public prayers. For Jesus Himself, prayer was not only an important element of worship, it was His life, the very breath of His being. It was the lifeline that kept Him connected to the Father. For the apostle Paul, too, prayer was the channel by which God expressed His grace in the church and sustained His people. As with Jesus, the apostles' life and breath revolved around incessant prayer (cf. 1 Thess 1:2; 5:17). 
That which was so vital to the experience of the individual was also essential to the life of the church, as believers joined together in corporate worship prayer. They "continued steadfastly . . in prayers" (Acts 2:42), whether in homes (2:46) or in the Temple (3:1). Exhortations and instructions for prayer set forth in the epistles were certainly meant for the believers whether in corporate worship or individual prayer. (See Eph 6:18; Phil 4:6; Col 4:2; 1 Thess 5:17; 1 Tim 2:1-2, 8.) Now, as then, prayer is our lifeline and the power that breathes life into the corporate worship experience.

In the Scriptures, we are provided basic instruction for prayer. In Phil 4:6, we are instructed, "by prayer and supplication, with thanksgiving, let your requests be made known to God." In 1 Tim 2:1-2, we are exhorted "first of all that supplications, prayers, intercessions, and giving of thanks be made for all men, for all kings and all who are in authority, that we may lead a quiet and peaceable life in all godliness and reverence. For this is acceptable in the sight of God our Savior."

Supplication signifies a petition for a definite need in a concrete situation. Prayer more generally is used for reverent and worshipful communication with God. When used in contrast to supplication, prayer may suggest the believer's general need of God and dependency upon Him for all things. In 1 Tim 2:1, supplication indicates "a confident interview which is 'in the interest of others,' and thus has the meaning of intercession."

Intercession literally means to fall in with a person, to draw near so as to speak intimately. In Old Testament times it signified freedom of access and became a technical

'William Hendricksen, 1-2 Timothy and Titus: New Testament Commentary (Grand Rapids: Baker, 1957), 92. 
term for a petition offered to a governor or king. Thanksgiving expresses that element of gratitude without which no prayer is complete.

Thus, the power of corporate worship prayer comes from interceding on behalf of God's people, offering supplication in times of dire need, and always giving thanks for that which is received.

\section{Practical Advice for Public Prayer Improvement}

Considering that corporate worship prayer should have the commitment of the entire congregation, worship leaders should consider some advice that will improve the quality of those moments of public prayer.

1. Prayer is a vital aspect of worship. Few worship services give importance to improvement of public prayer. Frequently there is little variation between prayers from one Sabbath to another. Ellen G. White offers advice for improving the public prayer experience:

Let those who pray and those who speak pronounce their words properly and speak in clear, distinct, even tones. Prayer, if properly offered, is power for good. It is one of the means used by the Lord to communicate to the people the precious treasures of truth. But prayer is not what it should be, because of the defective voices of those who utter it. Satan rejoices when the prayers offered to God are almost inaudible. Let God's people learn how to speak and pray in a way that will properly represent the great truths they possess. Let the testimonies borne and the prayers offered be clear and distinct. Thus God will be glorified.'

Note that prayer is a "power for good." It is a two-way communication, being one of the "means used by the Lord to communicate to the people the precious treasurers of

'White, Testimonies for the Church, 6:382. 
truth." What could be more vital than the ability to enter into communication with God himself?

2. Prayer is an opportunity for intercession with God. It is a time to acknowledge His presence and seek His leadership. Prayer is an opportunity to express humility before Him, making confession of sins, asking forgiveness for sins. Through prayer, we offer ourselves to God, petition for daily needs, thank God for blessings, and intercede for others. Intercessory prayer offers us a valuable opportunity to selflessly present the needs of others at the throne of God, to love one another, as He has loved us.

3. Corporate prayer is not one man talking to another. It is a profound conversation with God. It is not an attempt to impress others with oratorical skills. It is the interaction of a group, with God, under the leadership of one person. The prayer of the leader offers direction, while all stand ready to receive inspiration. The secret here is to involve those members who have the gift of prayer, those with spiritual leadership ability, to lead in this important part of the worship service. Those who lead the prayers of the people should be spiritually mature, fervent, discerning as to the needs of the congregation and the world, absolutely familiar with the congregation, and spiritually respected by the church. They should be virtuous people who have a very personal, oneon-one relationship with God. One lacking these abilities can hardly be expected to properly convey the needs of the people before His heavenly throne.

Prayer in corporate worship is not complete without a time of contemplation, allowing the congregation to hear the voice of God responding to their petitions. Some worshipers are very impatient and uncomfortable with silence. Many do not understand 
the need for this time of silence. Church leaders will greatly improve these moments of prayer by teaching the congregation to understand, appreciate, and use silence to complete their communion with God. The desired two-way communication, between God and His people, becomes hampered if the party asking the question is unwilling to listen for the answer.

4. The content of prayer. The possibilities for prayer are endless. Those things which might be included in prayer are numerous. Some prayers will be broad, others will confine themselves to one line of thought. Corporate prayer offered during the worship service should include five elements. Let us think of these five elements in relation to the word "A-C-T-S," remembering that prayers without "acts" are offered in vain.

" $A$ "stands for adoration, with which every prayer should begin, as does the Lord's Prayer. "C" reminds us of our need for confession. "T" brings us to thanksgiving for the rewards of life. "S" is the time of supplication when we make our definite petitions. Note that thanksgiving comes before supplication. Because of the nature of God and prayer, we are able to give thanks knowing that before we even ask, our prayers are answered.

We may want to add another "S" for submission, for only as we are able to say "not my will but thine be done" have we arrived at the true spirit of prayer. It is important to teach the people that God answers all prayers, but that many times our will and His will are not aligned. It is often hard for people to understand that, with God, no answer is indeed an answer.

5. Public prayer should be brief. Giving suggestions on the length of prayer Ellen G. White recommends that public prayer "should be brief but should include adoration, 
thanks, and mention of the personal needs of the worshipers, as well as of the great world field." In like manner she pointed out that "Christ impressed upon His disciples the idea that their prayers should be short, expressing just what they wanted, and no more.... One or two minutes is long enough for any ordinary prayer."2 At the same time she makes an appeal to the SDA worship leaders that "when you pray, be brief, come right to the point. Do not preach the Lord a sermon in your long prayers." ${ }^{\text {L }}$ Long, verbose prayers encourage people's minds to wander, which in turn defeats the purpose of prayer.

6. Characteristics of public prayer. People who lead the congregation in prayer should consider the following characteristics which honor God and help the worshiper draw closer to Him: (a) focus your prayer on God alone; (b) offer your prayer reverently and respectfully; (c) lead prayer in a simple and direct manner; (d) use corporate language such that everyone feels involved in the prayer; (e) offer prayers that have a specific purpose; and (f) use biblical patterns and language to build up and bring power into the prayer.

7. Public prayer deserves preparation. Many believe that prayer should be spontaneous and moved by the Spirit. But, in reality most people do not like to be surprised by being spontaneously asked to pray. To do so, shows lack of respect for the congregation. Improvement in prayer requires that church leaders inform church members ahead of time about a request to lead in public prayer.

${ }^{1}$ Seventh-day Adventist Church Manual, 87.

${ }^{2}$ White, Testimonies for the Church, 2:581.

${ }^{3}$ Ibid., 5:201. 
When leading public prayer, use a natural voice, vocabulary, and rhythm. Some leaders try to make their prayers beautiful by changing their voice, using difficult words, inflecting a strange intonation. To do so, merely creates a distraction. It must always be remembered that the beauty of prayer is not in the hands of the one who prays it, but comes as a gift from the one to whom we pray.

8. Elements in public prayer. The person in charge of leading public prayer should think through the prayer in advance. It should be relevant to the needs of the congregation. In the SDA church, we think of prayer as possessing seven basic elements. Every element need not be included in every prayer. The order of the elements is significant. For example, we must first show reverence for God, and get ourselves "right" with God, before asking anything of Him. The prayer elements referred to are:

a. Addressing God: Remember God's name is holy. Use it in prayer, but do not repeat it meaninglessly.

b. Praise: Adore God's name, and show appreciation for all He has done.

c. Repentance: Ask His forgiveness for the sins of the individual and for the group.

d. Dedication: Ask His strength for the future. Commit yourself, and the congregation, to Him before requesting things of Him.

e. General intercession: Intercede for God's people, world leaders, and your congregation, including the young, old, parents, ill, discouraged, etc.

f. Specific intercession: Remember special prayer requests, the meeting itself, and the speaker. 
g. Conclusion: Affirm the right by which we approach the throne room: "In Jesus' name."

Having time to spend thinking about these elements can make a big difference in the quality of public worship, especially as church leaders involve more people in leading public prayer.

9. Involvement in public prayer. There are many ways to pray. Occasionally, try having five different members share the prayer, each praying for one of the five basic elements (i.e., praise, repentance, dedication, general intercession, and specific intercession). This offers interesting possibilities, removes the discomfort often experienced by those members not used to praying in public, and offers an opportunity to involve the congregation's children.

Another possibility, instead of one person offering the entire prayer, is to have a prayer leader who directs the congregation by first opening the dialogue with God, then suggesting topics for everyone to join in silent prayer. The prayer leader should pause a few minutes after suggesting each topic.

Some small "family" churches experience a very good quality time of prayer by asking the congregation to share the blessings received during the past week. Members show how God has worked in their lives, and all are enriched by the experience. Often this time of sharing is followed by the congregation requesting prayers for their loved ones and needs. The depth of emotion and concern shared during this time might be surprising. During this sharing time, the prayer leader might make notes of the blessings and concerns

${ }^{1}$ Seventh-day Adventist Minister's Handbook, 151. 
offered, then incorporate them into a final intercessory petition, on behalf of the congregation. Another possibility might be to follow these petitions with quiet music while a silent prayer time is experienced by the congregation. A lot will depend on the different character of each church.

Other churches like to conclude the collective prayer with the Lord's Prayer. This prayer is a spiritual marker, known for its ability to center our devotional life. It is a prayer that has been used by many people for eons of time. This prayer is often thought of as Jesus' prayer and focuses us on the very meaning of what it signifies to be a Christian.

Leaders must remember to try different ways of performing the same worship element. There is no one "right" way, and the possibilities are endless. Varying this time of worship will help to keep the Spirit alive. Monotonous prayer is dead prayer. It brings life and joy to no one.

\section{The Importance of Scripture Reading in Worship}

Scripture reading is another central element in worship. Scripture reading, when poorly done, brings distraction to the worshiper listening and detracts attention from God's Word. Lack of variety in Scripture reading detracts from the power of the service, and inhibits worship improvement. The important thing is that the congregation must be able to hear the Word of God, in all its power and greatness, without any distractions. In some churches this may be accomplished by having a chosen, solo reader; in others there may be select members of the congregation willing to read when asked, and still, in others, the Scriptures may be responsively read by the congregation. 
Sadly, Scripture reading no longer holds a central place in the worship services of many churches. The people still claim to love God's Word, and base their lives on it, but if this is judged by the amount of time spent reading the Word, in corporate or private worship, the commitment becomes questionable.

Some churches do set aside time for Scripture reading. Some churches incorporate portions of the Scriptures, both the Old and New Testaments, into their worship to be read by members of the congregation. This is an effective way to involve both older and younger people, providing once again that the quality of the reading does not detract from the message. One way to avoid this is to assign passages a week or more in advance. This allows time for the reader to practice reading the passage, but it also means that the sermon deliverer must be preparing well ahead of time. It requires time to plan, and it will take time during the worship service. It may be necessary to rearrange the order of worship to accommodate this much congregation participation. But, little things like these make the service more interesting, enrich the experience for the congregants, and ultimately provide more glory to God.

Scripture reading is the foundation of all worship and must be a central part of the SDA worship experience. Jesus gave us the example when He began His public ministry by reading from the Scriptures in the synagogue in Nazareth (Luke 4:14-21). Years later, Paul gave instructions that the epistles should be read in the churches (Col 4:16; 1 Thess 5:27). A well-prepared and well-chosen Scripture reading can improve the quality of the service, and help to integrate all the other worship elements. The Scriptures chosen can provide the central theme around which the whole service evolves. 
Demonstration of this happened when the Levites "read distinctly from the book, in the Law of God," then they "helped them to understand," and when they did, "all the people wept, when they heard the words of the Law" (Neh 8:8, 9). The Word itself, when understood, carries the power to move the hearts of the congregation.

All elements of the worship service should be regulated by the principles of the Word of God. As the theme of the worship service is developed, based on the Scriptures, it will become apparent that our approach to Scripture reading does not merely focus on isolated passages of Scripture that speak explicitly of worship practices. Rather, our approach is a broad redemptive/historical one which seeks to discern how the worship of the church is shaped and formed by mighty acts of God as a whole. As those acts of God are revealed through the Scripture reading, and integrated with all the other elements of the worship service, we begin to elevate the excellence of the worship service.

As this occurs, exciting developments in worship service improvement happen with an increased emphasis being placed on the public reading of the Scriptures. The SDA church traditionally has a high view of Scripture as the inspired Word of God. How appropriate that we place more emphasis on the careful preparation of the public reading of Scripture. This applies not only to the reading of Scripture before the sermon, but to all reading of Scripture. How has it happened that something as important as the Word of God has been relegated to a staid position, typically only being read prior to the sermon? Here are some suggestions to more fully integrate Scripture reading into the worship service:

1. Encourage the Scripture reader to read the passage aloud several times. The 
inflection used by the reader, during the oral reading, allows the listener to hear those places where decisions have to be made, to more easily understand who is saying what, and to understand what a verse actually means.

2. Identify one person in the congregation who has the gift of reading Scripture effectively and who can identify and cultivate that same gift in others. Through this person, develop a list of five to twenty readers. Use people who do a good job of reading. Seek to use people who not only have the potential but also are not involved in worship leadership in any other ways (i.e., if Mary or John already sing solos, do not ask them to read on that service). Scripture reading is one way young people can be meaningfully used in worship, on a regular basis, instead of just in an annual youth service.

3. Use different people to represent different characters in the passage reading. Consider John 21:15-25, where Jesus reinstates Peter after he denied Jesus, asking Peter three times, "Do you love me?" Having three people read this Scripture (narrator, Jesus, Peter) can make this Scripture reading a powerful experience. ${ }^{1}$

4. Memorize Scripture. All by itself, reciting Scripture from memory does not guarantee effective communication of Scripture. But, when committing Scripture to memory is combined with other ways of presenting the Scripture, we can expect the Holy Spirit to use such diligent work in mighty ways.

Paul wrote a letter to Timothy giving the following advice: "Until I come, devote

${ }^{1}$ See Mirian B. Maddox, Dramatized Bible Readings (Grand Rapids, MI: Baker House, 1980); Michael Perry, ed., The Dramatized New Testament (Grand Rapids, MI: Baker House, 1994); idem, ed., The Dramatized Old Testament (Grand Rapids, MI: Baker House, 1995). These three volumes present most of Scripture in parts for such readings. 
yourself to the public reading of scripture, to preaching and to teaching" (1 Tim 4:13). It is impossible to believe that an effective worship service could be complete without the Word of God being read and proclaimed. Making public reading more effective requires patience and practice.

In fact, when there is commitment and dedication to making improvement in the reading of the Scriptures, the time will come when the reader and listener will be so impressed by the Bible that they will never forget what they have heard.

Ellen G. White describes her experience concerning benefits she received from Scripture reading. She declares: "When I was only about eleven years old, I heard a minister read the account of Peter's imprisonment, as recorded in the book of Acts; and he had so impressive a manner that the details of the story in all their reality seemed to be passing before my eyes. So deep was the impression made upon my mind that $I$ have never forgotten it." Here it is once again illustrated that the quality of the reading makes a great difference in the effectiveness of the Scripture reading.

Worship leaders must be mindful to choose carefully key passages from the Old and New Testaments, using a variety of the best translations, so the worshipers can improve their understanding of God, which is impossible to do without an understanding of the Bible. The Minister's Handbook supports the idea of improvement in Scripture reading saying that the passages chosen must be relevant to the emphasis of the day, must be well read, and leaders must encourage audience participation. ${ }^{2}$

'White, The Voice in Speech and Song, 393-93.

${ }^{2}$ Seventh-day Adventist Minister's Handbook, 152-3. 
The Elder's Handbook suggests the use of responsive readings, utilizing a variety of readers to reflect the diversity of the congregation: male/female, young/old, married/single, different ethnic groups, etc. Leaders could record a shut-in member reading the Scripture, then replay it on the Sabbath, during the worship service. Another unique approach might be to prepare an illustrated Scripture reading. Many psalms lend themselves to illustration through nature pictures, etc.'

Yet another way to involve the whole congregation in the reading of Scripture is to call on everyone to read a passage simultaneously. Because of the many translations used by different members, the passage could be projected on a screen or a copy placed in the bulletin for all to recite. The responsive reading section of the hymnal book provides several good options for the congregation to read Scripture together. Leaders can encourage the congregation to read together every verse, or a pre-designated reader can read the non-bolded print, with the congregation reading the bolded print together. One drawback to this method is that sometimes the congregation pays more attention to making sure they do not read the leader's print, rather than to what the verses are really saying. Everyone has a different learning style, so a variety of methods should be employed.

There are times when an explanation of the Scripture verses to be read can help bring the passages to life. A preliminary word about the author, the people, or the church to which it was written, or the reason it is relevant today can make the difference between just reading a Scripture and having it speak to the hearts of those who are reading.

'Seventh-day Adventist Elder's Handbook, 143. 
Worship leaders should remember that the goal is always to lead the worshipers to God, and help them respond to Him. The reading of God's Word must be given the prestige it demands, if we are going to worship in spirit and in truth, because His Word is truth.

\section{The Priority of Preaching in Worship}

Although preaching has received great priority and time in the SDA worship service, there is room for much error during this portion of the worship service. Some preachers misuse this time by bringing personal ideas and agendas to the pulpit. Some may attack weaknesses of the congregation or attempt to impress the congregation with their deep thoughts and knowledge. An old lady was once heard to say to the preacher, "Beautiful sermon, sorry I could not understand anything." These are very common mistakes made by some preachers. During this block of time, the congregation is held captive. Preaching must be approached with the utmost reverence and respect.

Preaching is often considered the gem of the worship service, but should not be considered the total essence of it. There is no doubt that, historically, preaching is the primary instrument by which God's Word is proclaimed to His people. At the same time, preaching, separated from worship, becomes a solo-verbalization and "solos" are not positive characteristics of corporate worship. No worship element is greater than another, and all must be integrated together to achieve the desired effect.

Preaching is a challenge for the small SDA church. There is often need for improvement in preaching. Members asked will usually cite two different forms of 
reluctance to hearing the sermon preached. One, the preacher appears unprepared, or unable, to give a fresh, insightful, stimulating interpretation of the Bible. The second, the preacher is boring, possessing a poor ability to deliver the materials. During these sermons, the congregants rarely pay attention long enough to determine if the truth has been presented. A poorly prepared or presented sermon detracts from our central purpose-bringing the congregation closer to God. Consequently, those not totally committed to the Lord and the church will not be back for a second service. The sermon and the message delivered are very important.

In the worship service, the sermon should be an offering to God. If the preacher is a man or woman of God, every sermon should be the best offering he/she has to give. Church leaders must carefully select those the preaching is entrusted to. This is not just a matter of finding someone willing to fill the time.

Let us examine some principles to follow for improving and integrating preaching within the worship service. In Pastoral Ministry, Ellen G. White presents several recommendations to preachers which, if followed, will bring considerable improvement in the quality of preaching in the local church. Here is a collection of her suggestions:

1. If the minister is surrendered, the Holy Spirit will speak through every discourse and make it effective.

2. The minister should never present to others what his own soul has not felt.

3. He should not be satisfied using discourses that have been preached over and over again. Moreover, heaven is ashamed of preachers who do less than their best at this sacred task. 
4. The minister must make sure that the preaching is biblical. Many ministers take their texts from Paul and preach from the newspapers. Consequently, well-educated shepherds may still not feed their flock if they have not personally pondered the excellencies of the Scripture they are presenting.

5. Human assertions in preaching are of no value; the minister must let the Word speak to the people. Preachers who study their Bible prayerfully will see new beauty in every line. Meanwhile, they will find truths, both new and old, for the benefit of others.

6. Preach prophecy but center it on Christ. For many, the prophetic biblical truths are but obscurely understood. A lifetime can be spent trying to decipher prophecy, but without the divine relationship, the congregant may be eternally lost.

7. Preachers should study and learn of Jesus Christ and His character. Salvation through Christ, alone, should be the burden of every sermon. The true preacher ties every truth back to Jesus as the sinner's only hope. Many hearers want, and need, to continually receive clear explanation of the conversion process, of Christ crucified, ascended, and coming again. It should so gratify preachers that they will continually present these truths to the people. Remember that Christ-centered sermons come from Christ-centered preachers.

8. Preaching should be related to life. A good minister learns how to feed the flock. Consequently, the practical application of religion should have a place in every discourse. At the same time, sermons should fortify hearers for the daily battles of life.

9. Ministers should be aware of inappropriate illustrations. Many illustrations downgrade the sacred dignity of preaching. Flowery speeches and inappropriate 
anecdotes never convict the heart of the sinner.

10. Use good illustrations. When studied, Christ's illustrations make the truth plain. As He used imagination and parables, His illustrations caught and held the people's attention. He recognized the fallible nature of man and repeated His lessons often. He gathered illustrations from the customs and experiences of daily life. A good minister always remembers that the purpose of both illustrations and the incarnation is to teach the unknown through the known.

11. Ministers must both encourage the obedient and warn the disobedient. Guilt, wrong, and sin are parts of the Laodicean message that the Adventist preacher must not neglect. The message preached is not solely meant to entertain. But, care must be exercised to not "beat up" the congregation. The message in the end should always be that we have a living hope and that, as repentant sinners, we can receive the warmth of Christ's love.

12. As the master preacher, Christ through His message pierced the conscience and revealed the innermost thoughts. In like manner, preaching must reach both heart and mind. Tame truth cannot convert nor can sleeping ministers preach to sleeping people.

13. Preaching should include a direct appeal. Preaching is intended to win decisions by combining the theory of the truth with Christ's redeeming love. It should be offered in simple language, with touching earnestness, presenting the truth as it is in Jesus. The preacher's words should be select and their speech sound.

14. Preaching should not be derisive. At the pulpit, preachers should not assume attitudes and expressions calculated for effect. They should approach the pulpit with 
decorum. The unnatural strain of a forced voice, in an unnatural tone, wearies both the preacher and people. They should preserve themselves by following the rules of proper speaking and train their voice in such a way that it may be used to its highest capacity.

15. Preaching should not give people more than they can remember. When the discourse is too long, the last part detracts from that which preceded it and that part which is spoken in the first hour is of far more value if the sermon closes then. ${ }^{1}$

Preach from the Scripture

All preaching should be centered in the Bible with Scriptures pulled from both the Old and New Testaments. Excellence in preaching requires an open mind, with the preacher careful to ask, "What are the Scriptures telling me to say?" and not "Where can I locate Scripture to support what I want to say?" It is important to stay true to Bible content, and not twist Scripture meaning to suit our needs.

The congregation needs to hear the guidance, knowledge, hope, and encouragement that have come to the church for over two thousand years, from the passages of the Bible. Only through exposure can God's people understand that this is an instruction manual. While pondering the Sabbath-morning sermon, a preacher's heart and mind must be open to receive His inspiration. It is God, through the preacher, who must deliver each sermon. Even the weakest preacher, when preaching from divine inspiration, will say something worth hearing.

'See Ellen G. White, Pastoral Ministry (Silver Spring, MD: General Conference of Seventh-day Adventists, 1995), 187-99. 
It is true that congregants need to hear sermons on doctrine and duty, theology and ethics, belief and behavior. The challenge comes in achieving a state of balance. Sermons should not be used to flog the congregation. If we preach and teach correctly, the congregants will grow in the Spirit, maturing to the point where many problems never occur.

Many SDA churches have the tendency to preach heady sermons strong on exploring doctrine and prophecy, while spending less time teaching right principles of living and the love of Christ. Gordon Bietz points out that we come by that naturally, because SDA churches "grew up of deep study of Scripture, and sometimes we tend to be more focused on the head than the heart; more concerned with the law than the Lord."1 It may be one reason that many of our church services have become dry and lifeless.

It is commonly observed that the fundamentalist churches, although not doctrinally pure, are alive with the Spirit. Many churches would do well to strive to experience a more joyful preaching style. In this matter, Ellen G. White observed, "As a people, we have preached the law until we are as dry as the hills of Gilboa that had neither dew nor rain." Preaching needs to come from the heart, moving people to feel the Spirit of the Lord moving inside of them. We must cease to resist being lively during the worship service.

${ }^{1}$ Gordon Bietz, "Religion for the Head and Heart," Adventist Review, 8 January 1998, 29.

${ }^{2}$ Ellen G. White, "Christ Prayed for Unity among His Disciples," Review and Herald, 11 March 1890, 146. 
Preaching needs to be relevant to people's life, and through Jesus, they will receive the Water of life to their dry hearts. When we finally get this right, our people will experience real joy again. Sermons that address genuine needs and critical concerns mimic those of the Old Testament preachers and the New Testament parables taught by Jesus.

\section{Advantages of Planning in Preaching}

To experience improvement in preaching, church leaders should try to plan the preaching not only as individuals, but as a church. Yearly pulpit planning, although a foreign concept to most lay preachers, can provide some advantages. It helps to save time. It leads to discipline. It helps the preacher to grow, producing balanced preaching, and balanced preaching produces a balanced Christian congregation. ${ }^{\prime}$ With yearly planning, sermons will have continuity. This will tend to remove some of the stress involved in always trying to figure out what to preach. Coming together as a church to develop this plan allows the Lord to share His inspiration with the group, providing a direction for church growth.

Preachers need to keep in mind that when God's people come to worship, they need to hear from Him. They have been bombarded with secular messages all week long. They now need to be refreshed by His Word. As important as it is for God's people to express themselves to Him, it is more important that they hear God express Himself to them; that they be fed by His Word; that they be instructed in His ways; that they be

\footnotetext{
'See Seventh-day Adventist Minister's Handbook, 154.
} 
effectively restored by His power, so that can shine forth as a light to the world in which God has placed them.

Preaching is an awesome responsibility and must be entrusted to mature Christians. Christians willing to draw close to God, to be continually nurtured and fed by His word, are able to hear His guidance and effectively feed His sheep. We each have been given different gifts, and not all are called to preach. With a small congregation to draw from, inspired preaching will remain a challenge for the small SDA church. But, knowing it is the Father's good will to answer the prayers of His people and to fulfill their needs, it is a challenge that even the small SDA church can successfully overcome.

\section{Making the Offering Meaningful}

Many congregants, within our churches, have lost sight of the true benefit derived from worship service offerings. These will only become meaningful again when the offering ceases to be "just a donation." Because many have lost sight of its true meaning, the offering has become a hurried affair, an obligation to be gotten through, a place where corners can be cut, if the service is running over schedule. This unfortunate trend will be reversed only through prayerful planning, proper instruction, and time.

The offering has historically been a vital part of the worship service. While the Scriptures counsel us to "worship the Lord in the beauty of holiness," we are also exhorted to "bring an offering, and come into His courts" (Ps 96:9, 8). Through the presentation of our gifts, we give God honor and respect. The offering is a natural and essential part of the worship service. The General Conference of the SDA Church 
instructs its people that the "offering appeal should be brief, intelligent, and worshipful. It has an overwhelming potential for teaching the basic Christian concepts of self-denial, sacrifice, and trust."”

The offering was the high point of the worship service in the earlier church. It was the time of thanksgiving to God for all He had done for His people, and for the gift of His son Jesus Christ. As such, it was a time to celebrate what God was doing through His people. The offering was a specific and deliberate act of worship. It was a way to demonstrate the selflessness of the worshiper toward his God. It was a joyful time of acknowledgment that all had come from God.

The modern-day offering should also be a natural outcome of a grateful people recognizing that all comes from and belongs to God. The offering, as a worship action, is a reminder of who we belong to and for whom we live day by day.

Unfortunately, many churches have transformed this sacred act of worship into an act of "business-ship" where the appeal is monotonously, week after week, read from the "conference-book." Often included might be an appeal for new church windows or money to support some other church project. One might hear from the pulpit, "Today the offering goes to the church budget, please reach down deep into your pockets." Often a time for quick announcements, one might hear, "As the deacons collect the offering, give your attention to these announcements or to the special singer who is visiting us today."

By these seemingly innocent diversions, we detract from the importance of the offering worship element. It is impossible to come before the throne of God with the

${ }^{1}$ Seventh-day Adventist Elder's Handbook, 142. 
offerings of our heart, when someone is making announcements or performing special music. Not that in and of themselves either special music or announcements are bad, but they each have their own place in the worship service and should not be allowed to diminish the benefits derived from the offering element.

Meaningful offering is an expression of the obedience of the worshiper, an obedience based in love, not obligation. God looks into the heart of the giver to see if the offering ignites love, generosity, worship, or adoration. In Mark 12:41-42, we are provided a biblical example through the widow who gave her all.

Meaningful offering is an act of worship, the high point of worship if it is performed with honesty, and with a correct and humble spirit before God. As an act of sacrifice it is meant to bring the best of the worshiper before God. It is an expression of love and self-giving to God, used to glorify His name and share His love around the world. As such, the worshiper must give only the best of the best. Through offerings the worshiper learns discipline, and is provided the opportunity to truly see that God provides for all needs.

Meaningful offering is a symbol, a very important symbol. Symbols can have real meaning only when they are shared by those who know and value the meaning. An offering presented to God by His people is a symbol of love and obedience. Church leaders should strive to help congregants better understand the meaning behind this symbol.

Congregants must come to understand that an offering is not essential for God, but the true benefit belongs to the giver. God will exist without any of us ever giving Him 
another offering. However, our relationship and spirituality will not thrive apart from the regular offering of ourselves every day.

1. The motive behind giving. The highest form of Christian giving comes in response to God's grace. Giving is an act of love which, when offered to others, outwardly expresses God's love for His children. According to Christ, the love of one another is closely related to the love of God (Matt 22:34-40; cf. Luke 10:25-37). God is concerned with the needs of His children, and a church in love with God will reflect that concern through its giving. God specifically tells us that we will know His children by their fruits (Matt 7:20; Eph 5:9; Gal 5:22). In the New Testament, we are instructed that a ministry based on giving to others is a ministry to Christ Himself (Matt 25:34-40).

2. The measure of giving. Each is to give "as God hath prospered him" (1 Cor 16:2). The measure of giving is to be qualified by liberality (generosity) (cf. 2 Cor $8: 2$; 9:11-13; Rom 12:8), and as such is sacrificial. Liberality in God's eyes does not require great wealth, but may be displayed by those with the least. The poor widow who cast her two mites into the treasury, out of her "want," gave more than the rich person who casts in "much" but out of "their abundance" (Mark 12:41-44).

3. The manner of giving. The measure and manner of giving are closely related. Although God expects everyone to give a full measure, more important than the amount of the offering is the spirit in which it is given. The Lord loves a cheerful giver ( 2 Cor 9:7). The offering most acceptable to God emanates voluntarily from "a willing mind," "not grudgingly, or [out of] necessity" (2 Cor 8:11-12; 9:7). Giving is to be an act from which the worshiper gains real delight, and is an inspirational worship experience. 
4. The method of giving. The Scriptures teach that the practice of meaningful giving through offering is to be carried on in a systematic manner. The apostles gave instruction that on the fist day of the week each one should "lay by him in store, as God hath prospered him" (1 Cor 16:2). The discipline of regularly setting aside from the bounty we have been given is a part of the genuine Christian worship experience, and combined with other elements of worship will produce improvement in the overall worship service.

5. The reward from giving. Aside from the blessings of God that result from obedience, the Scriptures note specific rewards resulting from faithful giving. In 2 Cor 9:6, we are told that "he who sows bountifully will also reap bountifully." Although the reward should never be the motivation for giving, it does give the recipient pause to give "thanks to God for His indescribable gift" (2 Cor 9:15). As a church grows in the spirit of abundant sowing and reaping, it promotes fellowship, sharing, involvement, and demonstrates the unity of the church. It is a self-perpetuating state of being, increasing the giver's desire for further giving (Prov 11:24; Luke 6:38; 2 Cor 9:8-10).

Congregants are best taught by example, and, as such, it is up to church leaders to start the momentum which can change the attitude toward corporate giving. After spending time in fervent prayer, one pastor was moved concerning the need to improve the offering attitude in his church. During the worship service, he began framing the offering with Scripture readings and corporate prayer. Soon, the offering time evolved into a time of reflection and soul-searching. It became a time when the worshipers were 
encouraged to stand before God, asking Him to show them anything that would make their offerings more acceptable to Him.

We must remember that God tells us there are attitudes and sins that stand in the way of receiving the full blessing of our offering. Jesus taught: "Therefore if you bring your gift to the altar, and there remember that your brother has something against you, leave your gift there before the altar, and go your way. First be reconciled to your brother, and then come and offer your gift" (Matt 5:23-24). If each will practice His command, the offering time will be transformed. It will become a time of revival.

Church leaders should seek to make better use of this most significant worship element, never losing sight of its meaning for the church and for the worshipers. When congregants restore the true meaning of the offering to the church, that church is on its way to being revitalized and blessed.

\section{Children and Youth Involvement in Worship}

One of the most significant areas to take into consideration when planning the worship service is the involvement of our children and youth. Some believe children and youth must know they play an important part. Others believe the whole service should be planned with them in mind. Still others say, touch a child and you change a heart.

Regardless of your view concerning children and youth involvement, two things should be remembered. Jesus said to let the little children come to Him, and that we need to be like them in order to enter His kingdom. Jesus clearly establishes their value.

The SDA church, as many other denominations, has a full array of activities which 
separate children and youth from the adults during most of the worship day. The SDA Youth Sabbath School Department focuses 100 percent of its attention on children's activities, teaching them special songs and lessons. Some churches maximize the separation through offering a special children's church, following Sabbath School. Once a year during camp-meeting, again most of the worship activities are separated.

Years later, the time comes for grown children to go their own way. At this time, it is not uncommon to hear parents asking the congregation for special prayers, saying, "What did we do wrong?" In truth, might the reality be that the children were never really included or involved? What did we ever do to make this "their" church? Are peace, quiet, and solitude so important that we jeopardize a child's eternal salvation in order to preserve it?

God instructs us that we will worship Him for eternity as a family. How can we expect to be a family in heaven when we do not practice it here on earth? All people, big and small, young and old, need to be included and involved. Unfortunately, it is easier to find someone to care for them instead of training them to be a productive part of the family.

This is an area of improvement which well lends itself to the small SDA church. As much as possible, church leaders should make efforts to include all members of the family in the congregation's worship experience. Children who are involved are less of a problem. They are quieter, and tend to be more obedient. Fostering this habit of tolerance and cooperation, at church, can contribute much to the spiritual solidarity of the home. Families who learn to worship together have a better chance of staying together. 
As we seek meaningful improvement in worship, we will do well to look for ways to include our children and youth in the worship service. This realization is beginning to dawn in many churches, and innovative ways are evolving for including this population. Children and youth have a natural rhythm of worship that can be beautifully expressed in the worship service. They can add innocence, spontaneity, and often light, heartfelt, joyous moments. Connecting into their free, spirit-filled cadence of worship can often awaken joy in the hearts of many overly serious, staid adults.

Children and youth involvement in worship can enhance four different areas of corporate worship:

1. Worship can be full of wonder and awe. The atmosphere of a worship service should be one of reverence, showing love and respect for a holy and transcendent God. A well organized and planned delivery of the worship elements plays an important part in creating that atmosphere. Children and youth are often excluded because it is believed they will detract from these very elements. In fact, the exact opposite is true. Children and youth, when participating and involved, are more reverent and can increase the spirit of awe, transcending the worship experience for the whole congregation.

2. Worship is visual and sensory. It is well known that visual props increase the ability to learn and remember. Children and youth are used to learning with the assistance of banners, candles, pictures, scenes, colors, and textures. One specific example of these sensory stimulants is the telling of the Christmas story with the use of different visual props to represent the characters in the Christmas story. Churches that have watched the dramatic telling of this story on Christmas have been moved not only by the vividness of 
the narrative but also by the way they were almost miraculously drawn into the story. Having children and youth involved, and using some of these visual and sensory props, enriches the worship service for all as they seek to reach God.

3. Worship is centered in story. Children and youth involvement in worship can remind us of the power of story. For eons of time, the magic of the gospel unraveled as His worshipers told stories, sitting around the fire. Note that the stories never got old, and they never died. A story well told has the ability to transform both the young and old. Worship leaders should take the biblical stories seriously, as valuable tools for bringing the gospel to life. In this setting, the goal should not be to evoke moral lessons (i.e., be kind, don't push, share your cookies, be a missionary), but to draw everyone into the story itself, which has its own transforming power.

If the church worship leaders will step forward, investing this extra time to bring the service to life, including children and youth, the whole church will reap rich rewards and God will send showers of blessings.

4. Worship involves the whole body, not just the mind. What adult is not moved when children and youth sing a song with hand motions and body movements that give beautiful physical expression to the words of the song? The psalms have many references to our whole bodies being involved in worship. We kneel in humility before God. We lift up our hands in exaltation. Dance, as an alternative to dialogue, can capture the rhythm of biblical words, making the Scriptures come alive, and thereby elevating the Christian worship experience.

This emphasis upon physicality in worship can connect us with the very nature and 
importance of the sacraments. Once again, we find symbols playing a big part. Christ gave His very body and blood as an atonement for our sins. In humility, He washed their feet at the Last Supper. He healed with His hands. Children and youth may have a purer appreciation of the sacramental nature of worship. In their innocence, they have yet to spend years stressing, breaking down, and examining the cognitive qualities of the sacrifice versus the experience of it.

There is a lot we do not know about heaven. But one thing we can be confident of, from the Psalms and the Revelation of John, is that our worship will be more physically animated in heaven than it has been here on earth. (See Pss 95:6; 150; Rev 19:11.) In heaven, we will no doubt wonder how we were ever able to stay so still in our worship of God. In movement, we find freedom. In freedom, joy. We can greatly reduce the distance between our worship now and our worship in heaven, elevating our spiritual experience, by watching and learning from the physical animation of our children and youth as they joyously worship the true and living God.

Practical Ideas for Involving Children and Youth in Worship

Involving children and youth in worship requires determination, courage, time, patience, joy, and sometimes disappointment. But out of this effort comes the assurance that together we are worshiping God.'

This process may not take place overnight. Some congregations will embrace the concept more slowly than others. One simple way to very quickly and easily involve

${ }^{1}$ See Ann Calkins and Jack Calkins, Children in Worship (Lincoln, NE: AdventSource, 1998). 
children and youth in the worship service is to include a children's story. Possibly, the congregation's teenagers can be asked to select and present the story to the little children. The story can be read from the Scriptures and animated using visual props, or an object lesson can be prepared from scratch.

The next step could be to increase their involvement using some ideas presented in the Elder's Handbook. The Elder's Handbook presents the following suggestion: (1) prepare a handout with questions on the sermon and encourage the youth to listen for and write the answers; (2) tailor the illustrations in the sermon to the children; (3) with advance notice, ask a child or youth onto the platform to read the Scripture text or assign several of them an appropriate memory verse to recite at this time; (4) ask one of them to say the benediction, (5) plan the entire worship service around children and youth some Sabbaths during the year. ${ }^{1}$ Children should be encouraged to participate in the worship service. They should be encouraged to join in the hymns, readings, or any other worship element. If they are not used to doing so, they will learn fast. Church leaders must trust their youth.

The church at worship must recognize each child or youth as a unique individual, help each one belong, and allow each one to participate actively, thereby enabling the whole congregation to grow in grace and faith.

The goal of involving children and youth in worship is to help them perceive, organize, and interpret the world as Christians by (1) having the freedom to articulate and share their own view of the world; (2) learning how to use concrete religious language in 
simple, declarative sentences that avoid relational, complex, and metaphorical language; (3) having opportunities to experience all aspects of worship; and (4) being able, within their limited experience, to imitate behavior consistent with the Christian faith. The following guidelines will assist the church leader in realizing these goals:

1. General principles in involving children and youth in worship. As church leaders seek to integrate and improve the involvement of their children and youth in the worship service they should (a) encourage families to pray together and to worship together; (b) encourage all children and youth to come to worship; (c) encourage all ages to work together in worship; and (d) encourage children and youth to participate actively in all worship element actions.

2. Involving children and youth before the worship service. Children, from a young age, need to be as involved as possible, in all aspects of the church. Before the worship service begins leaders could give them a tour of the sanctuary; let them help clean and prepare the sanctuary for worship; design a special bulletin just for them; and encourage them to look up the Scripture texts in the Bible, the hymns, and the responsive readings.

3. Involving children and youth during praise and preaching. During the worship service worship leaders should encourage them to sing the hymns of praise. Let them introduce new hymns to the congregation. Have a special children's song book from which the congregation can sing some of its hymns. Help them act out the hymns for the congregation. Encourage them to read along with the Scripture readings. Let them read the Scripture to the congregation; it will require much practice but is worth the effort. 
Have sermons be inclusive of their needs and experiences at different points throughout. Preachers could have pertinent questions, during the sermon, that they direct to the youth.

4. Involving children and youth at responses and offerings. Another practical way to involve them is to have them act as usher, collecting the offerings, and leading in prayer to bless the offering. At the offering, encourage them to place money in the collection plate, or a slip of paper pledging a good deed, a slip of paper asking for a special need, or one expressing a dream or hope.

5. Involving children and youth at the benediction. As the worship service comes to its end, leaders could also be creative in involving them with the congregation. Let them lead the congregation out or invite them to greet people as they leave.

\section{Treating Youth as Real Worshipers}

Looking at many small SDA churches it is easy to describe what role the youth have in the Sabbath worship service. Usually, we can identify their part very quickly. They may help the deacons once a month. If they are sufficient in number and the music they do is acceptable by the leadership, they may be involved in a special musical selection on special occasions. Or, in many churches they are just viewed as a distraction.

In churches looking for improvement in their worship experience, the amount of exposure that the youth have in worship is important. Often churches have one or two small jobs that a select, well-behaved number of children are asked to help with. But, what a difference could be made, if children and youth could be involved and assume responsibilities in worship, just the same as the adults. They could assist the deacons and 
deaconesses. Youth could help prepare the communion elements, help prepare for foot washing, help in the worship plan, be part of the worship committee, and could assume "adult" parts in the worship service rather than "youth" parts.

Many children and youth are musically talented and have made significant contributions to the SDA church in recent years. Churches wanting to become more dynamic in recent years have called upon their youth to play guitar or keyboard. Young people rarely deny an opportunity to contribute to the church what they love doing. However, music is not the only talent the children and youth have to offer. Using some of these other gifts they should be allowed to become more involved.

The SDA history shows that youth have always been involved in a variety of activities. Ellen G. White, at sixteen, accepted the challenge of leadership. Ann Smith accepted the editor's position at the Review and Herald, at a very young age. Today we are used to see pictures of our pioneers after they retired; but we would do well to imagine their pictures when they were first called and challenged to lead this church.

What young people do, and do not do, during the worship service indicates generally the view that adults have toward them, and how they are treated in the total life of the church. They have been isolated too long within their own structures, organizations, programs, and by their contributions in music.

The best suggestion this study could present is to involve the youth in the worship service. They are young. Their culture, likes, and dislikes are different. Let us cease to debate their behavior, their music style, their instruments, their post-modern world, or to doubt their spirituality level. Actions speak louder than words. The true indication of 
how we esteem our youth will be self-evident in how involved they are in the Sabbath worship service. Try to develop specific guidelines for children and youth involvement in such a way that their participation is specific to their age and ability.

Visiting a church not too long ago, the pastor called all children up to the front before starting to preach. For a moment, he gave the impression that the children's story was about to begin. Unfortunately, that was not to be. He called them forward, gave them some toys, and asked them to go out because the message that day was not appropriate to them. With the toys in hand, he excused them to leave. Church leaders must remember that people, including children, are not made for worship services. Worship services are made for people, including children, to help them draw closer to God and be reconnected with Him.

Church leaders who doubt their ability to hold the interest of children and youth need to remember that most preachers possess greater power in this regard than they have ever exercised. They have simply never devoted themselves to the task. Planning to integrate children and youth should involve the same meticulous care as planning for adults. The message designed to include them will better hold the attention of the adults, also. In fact, the preacher may on occasion be somewhat discomforted to discover that the discourse to the younger elicited more congregational response than did the main, traditional sermon. Sometimes it takes a talk to the youth to demonstrate to adults some of their own misconceptions of truth.

In small SDA churches, where lay leaders do much of the preaching, the congregation must work together to involve children and youth. The extra effort, 
although well worth it, must be shared by everyone. In fact, a small congregation needs the assistance of all possible congregants. Children and youth should be encouraged to embrace their part of the work.

As we examine the current level of involvement of children and youth in most SDA churches, we might question whether we are a people too intellectually oriented. Are we so haughty that we think they have nothing to offer? Children and youth are entitled to be heard, to be involved, to be seen, and to be present at the worship service. However, each church leadership must decide how best to include and involve all of its members within the worship service.

\section{The Impact of Public Testimony}

The main purpose of public testimony is to encourage members to share with the congregation during the worship service a personal experience which has led them to God, in a special way. Consequently, it creates an impact on the congregation causing them to grow in their faith by witnessing a live demonstration that God works in the midst of His people.

Nothing can create a bigger impact than a well-presented testimony. Testimony in the worship service helps to create an involvement and identification between the person involved in the testimony and the whole congregation. Especially, in small SDA churches, were the worship service can be more flexible, the impact of testimony has been a successful tool used to help others make a decision to accept Jesus as their Savior. 
Today, the most watched television programs around the world are those where people personally share what they think and believe. Sometimes in spiritual life, a person may refuse the gospel because of lack of faith. They may decline advice from spiritual authors such as Ellen G. White, or may deny the facts of prophecy; however, the impact of a personal testimony is hard for anyone to pass up without at least a momentary consideration.

God has blessed us with the power of speech. He gave us a tongue to proclaim His glory. God's blessings should not be ignored. In corporate worship, moments should be set aside for His people to share the power of God acting in their lives.

Some small SDA churches have experienced success with some Sabbath worship services where the message was presented only with personal testimonies. In order to be successful, this experience needs to be planned, individuals contacted, and time limited. Long testimonies can create a distraction in the worship service. Negative experiences, also, should be avoided, because worship has the ultimate purpose to glorify God and His majesty and not the enemy as he tempts our faith.

Testimonies should place greater emphasis on the blessings rather than the trials. The focus should always be on God. When we present God's power in worship, our trials will look so small that we shall forget to mention them. As Christians, we each should have experienced many blessings, and these should be cultivated, with the testimony time used to talk about the goodness of God.'

'Ellen G. White, "Requisites to a Good Prayer-Meeting," Signs of the Times, 4 December $1884,475$. 
This is a special worship experience, and is best not repeated every Sabbath. The worship leaders can use this as a tool to bring encouragement to the congregants, and will determine when it is appropriate to have testimonies.

In order to be effective the testimonies should be short and timed, and of a nature to uplift and help others. Everybody willing to lift up Jesus through testimony should be encouraged to make plans and be involved in this special worship service at some time. However, "nothing will so completely kill the spirit of devotion as for one to take up twenty or thirty minutes in a long testimony. This means death to the spirituality of the meeting."

The impact of public testimony can also act as a powerful tool for evangelism. Sally Morgenthaler believes that it happens in two ways: first, as unbelievers hear the truth about God through worship songs, prayers, Scripture, and testimonies and, second, as they observe the life-sustaining relationship between worshipers and God, which is real-life testimony, evangelism takes place and the service becomes total worship. Consequently, "worship that edifies, witnesses; worship that witnesses, edifies.""

\section{The Value of Benediction}

Despite the fact that it is traditional and thus an affront to those people who want to abandon traditions altogether, a benediction is a dignified and scripturally proper way to end a worship service. The words of an appropriate benediction tie the worship service

'White, Testimonies to Ministers and Gospel Workers, 171.

${ }^{2}$ Morgenthaler, 88 . 
together and send the worshipers away on a positive note.

Many churches deny the value of ending the worship service with a well-prepared blessing and benedictions. In general, as soon the preaching ends people begin to stand and walk away. There is a lack of understanding of the meaning of benediction and also perhaps a lack of preparation and improvement on the part of the leaders for sending people home with a blessing.

This closing prayer constitutes a climatic moment in the service. It should be spoken with deepest reverence, never mechanically or in a hurry. The worship leader should avoid giving the impression that he/she is just exercising a sacerdotal function. The leader is simply asking God's blessing upon the people.

Benedictions can be approached in two ways. Biblical benedictions can be offered and should be repeated exactly. The three most common are the priestly benediction (Num 6:24-26); the apostolic benediction (2 Cor 13:14); and the covenant benediction (Heb 13:20-21). On the other hand, there is no reason why the worship leaders should not offer up their own benediction. In this closing prayer, some leaders choose to raise their right hand, others raise both their hands, after the custom in the synagogue.

In the Scriptures we can see that all the letters end with blessings and benedictions. But these endings were not just signals to stop the meetings, in the way that the school bell announces a change of class or the end of the day. They were more than courteous good-byes. They were genuine blessings, with significant meanings for Christians as they parted.

Grace, love, and mercy are words appearing in the benedictions which close the 
biblical letters (i.e., 2 Pet 1:2; Jude 2; Gal 6:18). All of them underline God's generosity toward us. Through these benedictions we can receive love and mercy, healing and salvation. The God of peace is the giver of grace, and those who receive the generous gift will be more able to live in peace. Every congregation should be able to go home in peace with the assurance that Heaven has been petitioned on their behalf, and with peace in their heart. Offer grace as a gift and peace as the outcome.

In the Beatitudes (Matt 5), the word "blessed" used by Jesus describes a life filled with such a "grace-full" peace. Blessed, happy, fulfilled are those who are able to live in humility and meekness, craving justice. You are really living, Jesus told His disciples, when you live like this: when you are a reconciler, when you take the brunt of opposition, when you weep for the world. God's grace will enable us to live the life of the Beatitude. And that life is the life of biblical peace. The life which worshipers expect to live after receiving the benediction at the worship service.

When we use biblical benedictions, the expression "God of peace" flashes and merges with a kaleidoscope of meanings from God's Word. In the same light, going out from the worship service with a "shalom" benediction in our hearts can give us renewed strength for our engagements with the everyday world. The rainbow of God's peace shines over the whole world. Shalom is not just for a privileged few. This is clear in John 20:21, where Jesus combines the peace greeting "Peace be with you!" with the "mission" words "As the Father sent me, so I am sending you."

The Father sent the Son into the world to reconcile, to save, to bring peace. Then Jesus sent His disciples to carry on His mission. As His disciples, it is our responsibility, 
our mission, to radiate that peace to the people we connect with on a daily basis. So the key words in our benediction should be grace, peace, and mission.

At the end of the benediction, prior to exiting the sanctuary, the final element of worship should be to encourage God's people to live the worship experience in their daily lives. As the worship service concludes, congregants should be encouraged to rededicate their lives to God and to the ministry of the church, with the assurance of Christ's blessing as they set forth to do His will.

The final message blesses the people and sends them forth as a light into the world. People need to go home with the assurance that God will be with them until the end. This brief moment most usually takes the form of a spoken blessing that may be followed by an uplifting song of going forth. After the song is completed, the music continues to play as the people mix, say farewell, and depart the sanctuary.

At this point, if the church leaders have done their job well, the congregation should be ready to go home, encouraged to go forth with a sense of mission, with power, and peace. Although the SDA church hymnal offers only fourteen benedictions, worship leaders should develop a repertoire of benedictions that complement the themes of the sermon and prayers of the day.

\section{Conclusion}

The SDA church has never dictated a particular order or pattern for these eight worship elements discussed above, nor are we doing so in this project. But these eight elements of worship have been presented, historically and theologically, as simple but 
powerful elements that, when integrated into the worship service, become a way to present the fullness of the gospel of Jesus Christ, and to draw the full, conscious, and active involvement of all worshipers.

Presented within this dissertation has been a standard that can be used to assess, plan, implement, and evaluate the worship service in a local, small SDA church. Using the APIE model to compare a church's current worship elements to the eight worship elements presented herein is a way to quickly and easily identify which aspects of the worship service are particularly weak or strong.

As small SDA churches continue to strive for spirituality and growth through vital corporate worship improvement, I recommend that pastors keep using these eight elements of worship historically used by the SDA church. These elements emphasize the biblical principles presented in chapter 2 of this dissertation. They are biblically and historically sound, and allow church leaders to customize the worship service in accordance with the needs of the local church. These worship elements also meet suggestions for worship as described in the SDA Church Manual, the SDA Minister's Handbook, and the SDA Elder's Handbook. However, these patterns of worship elements should not be seen as suffocating creativity in worship; in fact, it is believed that the opposite is true. As in musical improvisation, free expression depends upon structure being established before freedom can emerge. So it is with these eight elements of worship. The integration of the worship elements with the APIE model provides the structure from which freedom and creativity can emerge.

We must not be fossilized by a rigid, set order for the church service, but must 
seek to provide improvement, integration, and involvement of all in the elements of the worship service. God's "frozen" people need to become His "chosen" people who will allow His spirit to breathe life and improvement into the delivery of the worship service.

This chapter maintains that the integration of the APIE model for improvement of the worship service, combined with the elements of corporate worship and infused with the Holy Spirit, can bring about the revitalization of any small church's life.

In order to accomplish these results it will be necessary to involve the majority of the congregation. They must be dedicated and committed. In one sense, there is no separation between the worship elements (i.e., music, prayer, Scripture reading, preaching, offering, children and youth involvement, testimony, and benediction) and the APIE model (assessment, planning, implementing, evaluating). In other words, although we have treated them separately, in reality the two must exist as a whole. No worship element by itself is a separate element of worship. Everything from singing to prayer, preaching to offering, involves a part of the body of the worship service and will require an equal effort if the improvement is to be done properly.

The New Testament worship, as presented on the day of Pentecost, offered an opportunity for dedication, commitment, involvement, and improvement on the part of the worshipers. It is a time to turn their lives over to God. Such opportunity still exists today. The modern-day worship service should become an opportunity to offer God the best we have in the form of a living sacrifice. Let us become a church that seeks to offer God the best.

In summary, every consideration in planning and integrating improvement to all 
elements of the worship service should be made with the thought in mind that each Sabbath is the anniversary of creation, and as such, it is the sole contact with God, the church, and its message. Every effort should be made to see that each worship element of the corporate worship service, the church, its leaders, and its people should put their best foot forward to improve the worship service. This effort will be based on the outcome required, after the assessment process, and the application of the APIE model. For in the end, we will thrill to the sound of our Heavenly Father saying, "Well done, My good and faithful servants." 


\title{
CHAPTER 6
}

\section{SUMMARY, CONCLUSIONS, AND RECOMMENDATIONS}

\begin{abstract}
Summary
This dissertation is not intended as an all-inclusive authority on worship-service improvement for the small Seventh-day Adventist church. Corporate worship improvement is an ongoing process. Once the APIE method has been utilized to assess and improve the worship service, at least annually, church leaders should continue to review and assess. It is hoped that the information and research presented in this study will contribute to more effective leadership in small SDA churches.

In chapter 2 of this study some Old Testament and New Testament principles of worship were presented, and possible applications to the current worship experience have been explored. Each biblical principle studied provides a valuable example of practical worship applications that church leaders should emulate in the small church today. The list of examples present is by no means exhaustive. Church leaders should follow this example, searching the Bible constantly for the guidance and wisdom that God has provided. If we look to the Bible, it will show us the way.

Chapter 3 presented some current worship practices in the small SDA church and challenges for revitalization. In addition, advice was offered to small church leaders, for
\end{abstract}


corporate worship improvement. Worship definitions and principles were taken from current worship literature. Challenges in leading the small church have existed for centuries and much has been written on this topic by contemporary authors. It is my belief that careful perusal of literature presented by these authors, ${ }^{\prime}$ together with the proposed suggestions, and always measured against the Bible, can prove valuable.

Chapter 4 presented the APIE Model. The APIE model, an innovative assessment tool developed in this dissertation, presents ways to improve and revitalize worship services through Assessing the congregation's spiritual needs, Planning properly for the worship service, Implementing the changes needed for the corporate worship service, and Evaluating the results. The APIE model becomes a living improvement model that can help revitalize the corporate worship experience, ultimately bringing people closer to God.

Finally, chapter 5 presented practical suggestions for integrating and applying the APIE model with the eight elements of worship, as suggested in the SDA Church Manual.

In my study the following themes were essential to a healthy understanding of worship and a successful strategy for worship improvement.

1. Congregational participation. Successful corporate worship demands a relationship between God and His people. Small SDA churches should do well to avoid those worship styles that impose a ministerial monopoly. God never intended for pastors, ministers, or worship leaders to become an intermediary between Him and His people.

'See Bibliography. 
Our only intercessor should be Jesus Christ. Worshipers gain the most value when they are participators and not just spectators. They should be involved, as much as they are able and willing, in the entire creative worship process.

2. Authentic personal worship experience is prerequisite. Corporate worship is one of God's instruments used to fulfill the intellectual, emotional, and spiritual needs of His people. Biblical worship, while emphasizing a personal relationship with God, can be incorporated into and enhance the corporate worship experience. These should be progressive experiences as most congregants need to develop that private, one on one relationship with God, prior to being asked to participate in the corporate worship experience. We must always remember to encourage congregants, but not to force them.

3. Corporate worship experience. Throughout the Bible the concept of worship is first personal, and then it is demonstrated in a corporate way. Corporate worship prepares God's people for that day when they will come together as a heavenly family, joining with the hosts of heaven, to worship our Creator and Savior, Jesus Christ.

4. Christ-centered worship. All worship services should provide the worshiper with an opportunity to seek God's presence, to draw closer to Him, and to honor the Lord. Worshipers leaving our services unfulfilled may never return. Corporate worship provides an opportunity to bring heaven to earth, allowing His people to come together as a family, experiencing that close relationship with Him, as Father. Such a level of worship mandates that the services be Christ-centered. Consequently, every church worship service must become a place for prayer, instruction, and the revelation of God's Word, under the influence of the Holy Spirit through the power of Jesus Christ. 
5. Biblical principles combined with APIE model. A close, continual study of biblical principles will reveal those guidelines needed for an effective revitalization of the corporate worship service at the small SDA church. Our Jewish predecessors set many examples for us to follow, and many are explored and discussed in chapter 2. If, through following the APIE model, we apply these principles consistently and correctly, an increased feeling of peace will be experienced by the worshipers. Worshipers will become more inspired to serve the Lord and one another, through the corporate worship experience. Christ-centered worship will become the priority of the church, and service will become its mission.

6. Improvement and revitalization. Decreasing membership in some small SDA churches tells us there exists a need for improvement and revitalization of the worship service. Many church services have been empty and void of a feeling of vitality and joy. The services must become more vibrant and relevant to all congregants. Many small churches must rely predominantly on lay leadership, which poses some significant challenges. These lay leaders are men and women with busy lives both in and out of the church. But I firmly believe that if small-church leaders can pull the congregants together, work through the APIE model, apply proper biblical worship principles, honestly assess the church's strengths and weaknesses, and develop an improvement action plan, less time in the long run will be spent planning corporate worship, and the result will be a far superior service, uplifting and spiritual for all.

7. Vitality and active engagement. Worship must be transformed. It must cease to be a purely human activity, one in which worshipers are merely passive spectators; it 
rather needs to become an active engagement with God. Small-church leaders must work within their churches to recapture the vitality of the church. The APIE model provides an inexpensive, relatively simple method by which lay leaders can receive instruction and training to assist them with this godly job to which they have been called.

8. Continuous improvement. As church leaders seek revitalization through the APIE model the church must be willing to openly evaluate all elements of worship. This will result in continuous worship improvement that will benefit everyone. Worshipers will be aided in their need to develop a closer relationship with God. The church will be rewarded by an increased ability to fulfill God's command to minister to His people, which in turn will bring joy to the Lord who will know that all His children are coming together to worship their Creator.

9. The APIE model. As the APIE model assists church leaders to "Assess" the congregation, "Plan" the worship service, "Implement" the elements of worship, and "Evaluate" the results, they will be more able to adapt their ministry, and the ministry of the church, to the needs of the people. It will help leaders by providing information necessary to make right decisions to improve the quality of worship. It will help congregants find their service niche. The church will come together more able to work as a team and spread the "Good Word." Everyone, together, will benefit from knowing that God is pleased from a job well done.

10. Assessment. The APIE assessment information, combined with church leadership experience and Christian judgement, will provide the foundation for defining 
corporate worship needs and creating worship services that address the spiritual needs of the congregation. Using APIE as an ongoing self-help tool will allow the church leadership to stay in touch with the worshipers, help them to be more aware of specific interests, and to keep pace with the changing needs of the church, resulting in continuous improvement in its worship experience.

11. Planning. Many worship-service failures can be attributed to the lack of planning or knowledge of lay church leaders. It is not uncommon for willing leaders to be placed into a church position for which they have no previous experience. The APIE model helps to bridge that gap. It provides a blueprint that even the inexperienced can follow. The APIE model, if prayerfully followed, will allow a church to be infused with new life, providing lay church leaders with a sense of accomplishment, versus a sense of frustration.

12. Implementation. This study also concludes that no matter how well any worship service plan is formulated, it will bear little fruit unless it is used. Through implementation all willing members should be involved and encouraged to share the blessing received from the experience. Although an excellent tool, the APIE model is not a magical fix. It will take effort. It will take trial and error. Worship service elements, and their implementation, are not ends in themselves, but only agents to an end. But the resulting service will take all involved to a higher Christian experience with God.

13. Evaluation. Church leaders willing to have an effective worship ministry must take time to evaluate the worship service on an ongoing basis. If they do not do so, once again they may see their congregation start to dwindle. Evaluation assists congregants 
and leaders to see things from a different point of view, and encourages the church to perceive more than one way of conducting the worship service. Not to evaluate is to miss the valuable learning experience that will come from improving the corporate worship service.

14. Integration of the APIE model with worship elements. In addition to APIE, church leaders must pay special attention to the eight elements of worship presented in the SDA church manuals. While most small SDA churches include some of the elements of worship (i.e., music, prayer, Scripture reading, preaching, offering, children/youth involvement, testimony, and benediction), they still must be open to change and improvement. The small size of the church does not excuse it from having quality in worship, delivered in the best way possible. It still must be dedicated, committed, and motivated for improvement.

15. Application. As an example, worship music is able to elevate the quality of the congregant's experience only when it has no other end than to glorify God. Many small churches do not have expensive organs or large choirs, but are still charged with making music which joyously resounds through the heavens. Churches must be open to looking at worship through music in different ways. Although some diversity in music is to be tolerated, the sanctity of the worship experience must be preserved. Although church members experience musical talent to a greater or lesser degree, the goal is for all to be uplifted through this worship element.

The power of corporate worship prayer, another essential element, comes from interceding on behalf of God's people, offering adoration, confession, supplication, and 
submission in times of dire need, and always from giving thanks for that which is provided. Prayer is the mechanism provided by God for talking to His people, and for His people to talk to Him. As church leaders we are charged with helping His people, through the worship service, to draw closer to Him. Does this worship element, in our services, currently accomplish its goal? Or, is the prayer service so devoid of life that congregants fall asleep on their knees? Churches must be willing to honestly assess these essential worship elements, finding ways to bring them to life, if they are found lacking.

Foundational in all worship services should be the Scripture reading. It, too, must be a central part of the SDA worship experience. If this element is being performed correctly, the time will come when congregants will be so mesmerized by the Bible that they will never forget what they have heard. Worship leaders must remember that the goal is always to lead the worshipers to God, and help them respond to Him. Like prayer, the reading of God's Word must be given the prestige it demands, because His Word is truth.

Preaching is often considered the gem of the worship service, but should not be considered the total essence of it. This is true especially in the small SDA church where there will exist a wide variety of ability in delivering an effective sermon. All worship elements must be integrated together to achieve the desired effect, but a sermon poorly preached or factually at fault can produce negative results. In this case the congregation's time would have been better spent in praying and reading the Scriptures. Preaching needs to be relevant to people's lives and of a high quality if congregants are to partake of the Water of life, Jesus Christ. Once again, church leaders must be willing to use the APIE 
model to honestly assess the quality of the preaching, and be more willing to take the actions necessary to change for the better.

The offering, as a worship action, is a reminder of whom we belong to and for whom we live day by day. Meaningful offering in worship is an expression of the obedience of the worshiper. Worshipers must come to understand that an offering is not essential for God, but that the true benefit belongs to the giver. God will continue to exist with or without our offerings. However, our relationship to Him and our spirituality will not thrive apart from the regular offering of ourselves to Him. When worshipers restore the true meaning of the offering to the church, that church is on its way to being revitalized and blessed.

As the small SDA church seeks meaningful improvements in worship, it will do well to look for ways to include children and youth in the worship service. Involving them in worship is a challenge and requires determination, courage, time, patience, joy, and sometimes disappointment. But, out of this effort comes the assurance that together all are worshiping God. Churches must recognize each child or youth as a unique individual, help each one belong, and allow each one to participate actively.

As a worship element, testimony can help create a level of increased involvement between the person sharing the testimony and the whole congregation. Nothing can create a bigger impact than a well-presented testimony. As one of the most powerful evangelism tools at our disposal, it should always be focused on God.

This dissertation concludes by studying the worship element that sends His people 
home with the assurance that God will be with them until the end. With the benediction, the worship leader should bless the people and send them forth as a light into the world.

\section{Conclusions}

Corporate worship is at the very center of the life of every church and needs to be relevant to all. The small SDA church is in need of godly leaders willing to fulfill God's command, taking the congregation through the corporate worship improvement process. The goal for these church leaders should be to help congregants grow in their walk with Jesus and become true disciples. Pastors and church leaders must make every effort to weave quality assurance together with meaningful worship components, to create a rich, meaningful corporate worship experience for all believers. All believers should be encouraged to participate in corporate worship improvement.

From experience and observation, I have seen the need to help the small SDA church develop a model for improving the corporate worship service experience. In this time of history, all churches, but especially the small SDA church, must be provided with effective tools to aid with its growth. The APIE model provides an inexpensive self-help tool that can be used by pastors as well as lay leadership to help the church grow.

The ultimate goal of this project has been to assist small churches to have more profundity and variety, to achieve more lay involvement, and to improve the worshiper's ability to understand and communicate the gospel message.

Today's pastors must train and equip church leaders in the ways of corporate worship and, as far as possible, allow them the freedom to develop ways to improve the 
corporate worship experience. Most pastors are experiencing increasing demands from their congregations for pastoral care at a time when their schedule already is overloaded and their emotional energies are drained. It is not uncommon for the pastor to shepherd more than one church. This model demonstrates the importance of a shared ministry and how every member's potential can be used by enabling laity to share the ministry of the corporate worship service.

The idea of developing a model to assess and improve the quality of worship in the small SDA Church and making it available to pastors and laity, at little or no cost, was one way I saw to assist in meeting the needs of the local congregation, for the betterment of the whole church worship service and, ultimately, for the glory of God. It has been a very challenging and rewarding experience.

\section{Recommendations}

Several recommendations have resulted from this project:

1. The creation of a training center for lay people in each Conference is recommended to provide formal Bible instruction such as doctrines and practical theology in private and corporate worship. This training center should not replace or diminish the importance of the local church as a training center. Providing training centers for the laity sends a message to all church members that their ministry is important. ${ }^{1}$

2. A magazine addressed to lay leaders should be published to give them support 1993), 110.

${ }^{1}$ Russell Burrill, Revolution in the Church (Fallbrook, CA: Hart Research Center, 
for the worship service providing practical advice to improve all the elements of the worship service. Since lay leaders work without pay for the church, this magazine should be sent free of cost to them.

3. A more effective training program for pastors should be sponsored by the Conference to teach pastors how to train local church leaders to improve the worship service. The Conference should be willing to sponsor a program that aids the development of its pastoral worship leadership potential.

4. The Conference should prepare specific materials in worship and supply them to pastors for the training of laity in the local congregation. Training materials are most effective when designed to meet the unique needs, interests, and resources of a particular church.

5. The concept that each church is a worship training center for its membership should be revived. A comprehensive worship training program in the church can become one of the most meaningful and important experiences in the life of the church and its members.

6. A successful worship training program should follow a certain sequence: Conference pastors should train district pastors, and district pastors should train local members.

7. Leaders must constantly remember that the church does not exist for their benefit; they exist for the benefit of the church.

8. This model of worship improvement in the small SDA church should be 
improved, adapted, and widely used by any Conference and wherever needed for the benefit of the worship services of local churches.

9. Finally, tolerance teaching is a condition for a successful training program. When dealing with such a sensitive and personal topic as worship, people need to learn to consider problems objectively, to articulate issues clearly, to tolerate cultural differences, and to communicate with mutual respect and dignity. 


\section{APPENDICES}


APPENDIX A

WORSHIP ELEMENTS PRIORITIES 


\section{WORSHIP ELEMENTS PRIORITIES}

Using last Sabbath's bulletin and this worksheet, analyze the elements of your worship service by placing percentages in the appropriate boxes. For example, what percentage of the Scripture reading was done in a spirit of Contemplation; of Celebration; and of Commitment? What percentage represents Participation by those present? Presentation by the up-front person(s)? The percentage of the Contemplation, Celebration, and Commitment should total $100 \%$ when added horizontally. The same is true of the Participation and Presentation boxes.

\begin{tabular}{|c|c|c|c|c|}
\hline \multicolumn{5}{|c|}{ Prelude } \\
\hline Contemplation & Celebration & Commitment & Participation & Presentation \\
\hline \multicolumn{5}{|c|}{ Opening and Pastoral Prayer } \\
\hline Contemplation & Celebration & Commitment & Participation & Presentation \\
\hline \multicolumn{5}{|c|}{ Congregational Singing } \\
\hline Contemplation & Celebration & Commitment & Participation & Presentation \\
\hline \multicolumn{5}{|c|}{ Offering Appeal } \\
\hline Contemplation & Celebration & Commitment & Participation & Presentation \\
\hline \multicolumn{5}{|c|}{ Scripture Reading } \\
\hline Contemplation & Celebration & Commitment & Participation & Presentation \\
\hline \multicolumn{5}{|c|}{ Children/Youth Involvement } \\
\hline Contemplation & Celebration & Commitment & Participation & Presentation \\
\hline
\end{tabular}




\begin{tabular}{|c|c|c|c|c|}
\hline \multicolumn{5}{|c|}{ Public Testimony } \\
\hline Contemplation & Celebration & Commitment & Participation & Presentation \\
\hline \multicolumn{5}{|c|}{ Special Music } \\
\hline Contemplation & Celebration & Commitment & Participation & Presentation \\
\hline \multicolumn{5}{|c|}{ Sermon/Preaching } \\
\hline Contemplation & Celebration & Commitment & Participation & Presentation \\
\hline \multicolumn{5}{|c|}{ Hymn } \\
\hline Contemplation & Celebration & Commitment & Participation & Presentation \\
\hline \multicolumn{5}{|c|}{ Closing Prayer and Benediction } \\
\hline Contemplation & Celebration & Commitment & Participation & Presentation \\
\hline \multicolumn{5}{|c|}{ Postlude } \\
\hline Contemplation & Celebration & Commitment & Participation & Presentation \\
\hline
\end{tabular}

Place percentages in the boxes below to reflect your analysis of the worship service as a whole.

\begin{tabular}{|l|l|l|l|l|}
\hline \multicolumn{5}{|c|}{ Entire Worship Service } \\
\hline Contemplation & Celebration & Commitment & Participation & Presentation \\
\hline & & & & \\
\hline
\end{tabular}


APPENDIX B

YOUR PERSONAL EVALUATION OF THE WORSHIP SERVICE

IN OUR CHURCH 


\section{YOUR PERSONAL EVALUATION OF THE WORSHIP SERVICE}

\section{IN OUR CHURCH}

Your church leaders feel that worship is a significant experience in which every Christian should be involved. What takes place on Sabbath morning is not a performance of those on the platform but an involvement of all people present under the direction of the worship leader.

In order to help the worship leaders know your insights and your needs, we request that you complete the following questionnaire. Please answer every question and write in additional comments if you desire. Please answer exactly as you feel. Your name is not requested.

\section{Background Information}

Would you first give some information about yourself by drawing a circle around the answer that applies to you?

1. Age: Under $20 \quad 20-29 \quad 30-39 \quad 40-49 \quad 50-59 \quad 60-69 \quad 70$ or older

2. Sex: Male Female

3. How long ago did you first become a member of any church?

Less than 2 years 2-5 years 6-10 years 11-20 years More than 20 years

4. How long have you been a member of the Seventh-day Adventist Church?

Less than 2 years 2-5 years 6-10 years 11-20 years More than 20 years

5. Marital Status: Married Single Widowed Divorced

6. Occupation:

7. Education (Circle highest grade completed):

$\begin{array}{lllllllllllll}1 & 2 & 3 & 4 & 5 & 6 & 7 & 8 & 9 & 10 & 11 & 12\end{array}$

College $1 \begin{array}{llll}1 & 2 & 3 & 4\end{array}$

Postgraduate $\begin{array}{lllllll}1 & 2 & 3 & 4 & 5 & \text { or other }\end{array}$

8. How often have you attended church worship experiences in the last three months?

a. Every time

b. Once a week

c. 2 or 3 times a month 

d. Once a month
e. Less than once a month

\section{Evaluation of the Total Worship Service}

Which parts of the worship experience are most meaningful to you? Recognizing that all parts of the worship service may be significant, try to select which parts are most meaningful to you.

1. Place a 1 in front of the most meaningful part of the worship service.

2. Place a 2 in front of the next most meaningful part of the worship experience.

3. Place an (x) in front of the least meaningful part.

_ Congregational singing

- Scripture reading

_ Special music

— Instrumental music-organ/piano/other

- Prayers

- Call to worship, prayer, benediction

_ Children/Youth moment

- Message/Sermon

— Offering

- Testimony

_ Lord's Supper and Baptism

4. In the worship service are is ways that express the triune nature of God.

$\begin{array}{llllllllllll}\text { Not at all } & 1 & 2 & 3 & 4 & 5 & 6 & 7 & 8 & 9 & 10 & \text { very much so }\end{array}$

5. In the worship service the story of God's work in history, the Good News aspect, and the relationship between heaven and earth is adequately expressed.

$\begin{array}{llllllllllll}\text { Not at all } & 1 & 2 & 3 & 4 & 5 & 6 & 7 & 8 & 9 & 10 & \text { very much so }\end{array}$

6. The worship service helps the worshipers identify their dislocation and helps to relocate them in God. The worship service interfaces with the needs of people present.

$\begin{array}{llllllllllll}\text { Not at all } & 1 & 2 & 3 & 4 & 5 & 6 & 7 & 8 & 9 & 10 & \text { very much so }\end{array}$

7. The worship service creates the feeling of awe and wonder in the worshiper.

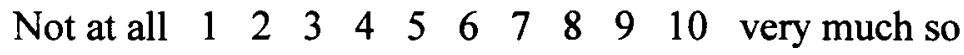


8. In the worship service it is possible to experience the following:
a. Intention:

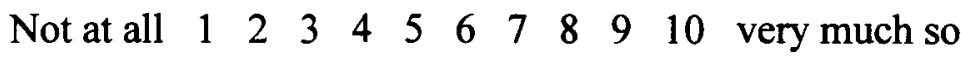
b. Imagination:

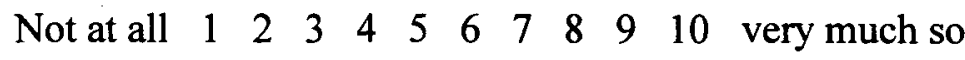
c. Contemplation:
$\begin{array}{llllllllllll}\text { Not at all } & 1 & 2 & 3 & 4 & 5 & 6 & 7 & 8 & 9 & 10 & \text { very much so }\end{array}$
$\begin{array}{lllllllllllll}\text { d. Celebration: } \quad \text { Not at all } & 1 & 2 & 3 & 4 & 5 & 6 & 7 & 8 & 9 & 10 & \text { very much so }\end{array}$
e. Commitment: $\quad \begin{array}{llllllllllll}\text { Not at all } & 1 & 2 & 3 & 4 & 5 & 6 & 7 & 8 & 9 & 10 & \text { very much so }\end{array}$

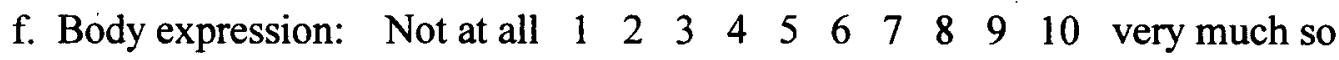

9. How the worship service appeal to your
a. Mind?

b. Emotions?

c. Will?

\section{Music in Worship}

1. Organ/Piano music (check the blank that indicates your response).

a. Do you find yourself aspiring to and preparing for worship during the prelude?

( ) Very often ( ) Often ( ) Occasionally ( ) Seldom ( ) Never

b. Does the offertory provide additional stimulus for your worship?

( ) Very often ( ) Often ( ) Occasionally ( ) Seldom ( ) Never

c. Do you normally listen to the prelude?

( ) Very often ( ) Often ( ) Occasionally ( ) Seldom ( ) Never

2. Other instruments

a. Do you enjoy the use of other instruments in the worship music?

( ) Very often ( )Often ( ) Occasionally ( ) Seldom ( ) Never

b. If yes, what instruments do you most enjoy hearing? 
c. Do you benefit by having a printed text to accompany instrumental selections? ( ) Very often ( ) Often ( ) Occasionally ( ) Seldom ( ) Never

\section{Congregational Singing}

1. Please list your three favorite hymns.

a.

b.

c.

2. Are you willing to learn to sing new hymns?

( ) Very often ( ) Often ( ) Occasionally ( ) Seldom ( ) Never

3. Would you like a regular opportunity for suggesting hymns to be used? $($ ) Very often ( ) Often ( ) Occasionally ( ) Seldom ( ) Never

4. Does the singing remind you of the SDA beliefs and bring relevance to your life? Very little Little Some Much Very much

\section{Anthems - Choir}

1. Do you normally enjoy the anthems the choir sings?

$($ ) Very often ( ) Often ( ) Occasionally ( ) Seldom ( ) Never

2. Do you benefit by having the printed text of the choral music presented by the choirs?

( ) Very often ( ) Often ( ) Occasionally ( ) Seldom ( ) Never

3. Do you prefer to have the younger choir to sing more often?

( ) Very often ( ) Often ( ) Occasionally ( ) Seldom ( ) Never

\section{Other Worship Aids}

1. Do you prefer the use of the following choral worship aids?

a. Choral call to worship

( ) Very often ( ) Often ( ) Occasionally ( ) Seldom ( ) Never

b. Offertory prayer response

( ) Very often ( ) Often ( ) Occasionally ( ) Seldom ( ) Never

c. Benediction response

( ) Very often ( ) Often ( ) Occasionally ( ) Seldom ( ) Never 
2. Do you prefer the use of the following music worship aids?

a. Doxology

( ) Very often ( ) Often ( ) Occasionally ( ) Seldom ( ) Never

b. Offertory Responses

( ) Very often ( ) Often ( ) Occasionally ( ) Seldom ( ) Never

c. How often do you prefer one of the above be used?

( ) Once a week ( ) Twice a month ( )

( ) Once a month ( ) Less than one a month

\section{The Use of Scripture}

1. Do you follow the Scripture reading in your Bible?

( ) Very often ( ) Often ( ) Occasionally ( ) Seldom ( ) Never

2. Do you enjoy hearing the Scripture read from different translations?

( ) Very often ( ) Often ( ) Occasionally ( ) Seldom ( ) Never

3. Do you like having an Old and a New Testament reading?

( ) Very often ( ) Often ( ) Occasionally ( ) Seldom ( ) Never

4. Do you like responsive reading of the Bible?

( ) Very often ( ) Often ( ) Occasionally ( ) Seldom ( ) Never How frequently?

( ) Once a month

( ) Twice a month

( ) Three times a month ( ) Every Sabbath

5. Do you find meaning in responsive Scripture reading between various worship leaders?

( ) Very often ( ) Often ( ) Occasionally ( ) Seldom ( ) Never How often?

( ) Once a year

( ) Once a month

( ) Several times a year

( ) More often then once a month

6. Do you enjoy unison Scripture readings?

( ) Very often ( ) Often ( ) Occasionally ( ) Seldom ( ) Never How frequently?

( ) Once a week

( ) Twice a month

( ) Once a month

( ) Less than once a month

7. Does the Scripture reading remind you of any of the SDA beliefs? Yes No 


\section{Congregational Readings}

1. Do you like a responsive call to worship?

( ) Very often ( ) Often ( ) Occasionally ( ) Seldom ( ) Never

2. Do you find meaning in a corporate confession or call to prayer?

( ) Very often ( ) Often ( ) Occasionally ( ) Seldom ( ) Never

3. Do you like a responsive offertory dedication?

( ) Very often ( ) Often ( ) Occasionally ( ) Seldom ( ) Never

4. Do you enjoy praying a responsive invocation?

( ) Very often ( ) Often ( ) Occasionally ( ) Seldom ( ) Never

5. Do you find meaning in a responsive benediction?

( ) Very often ( ) Often ( ) Occasionally ( ) Seldom ( ) Never

6. If you like responses, how often would you like one used?

$\begin{array}{ll}\text { ( ) Once a month } & \text { ( ) Twice a month }\end{array}$

( ) Once a week ( ) More than once a week

( ) Less than once a month

7. Do the congregational readings motivate you to spend more time in private Scripture reading? Yes No

\section{Prayers}

1. Do you find meaning in praying the Lord's Prayer in unison?

$($ ) Very often ( ) Often ( ) Occasionally ( ) Seldom ( ) Never

2. Do you prefer silent meditation before the pastoral prayer?

( ) Very often ( ) Often ( ) Occasionally ( ) Seldom ( ) Never

3. Do you find inspiration for your own prayer during the pastoral prayer? $($ ) Very often ( ) Often ( ) Occasionally ( ) Seldom ( ) Never

4. Do you enjoy singing a prayer, such as "As we come to You in prayer" for the prayer invocation?

( ) Very often ( ) Often ( ) Occasionally ( ) Seldom ( ) Never

5. Do the moments of prayer in church motivate you to a more active personal prayer life? Yes No 


\section{Lay Worship Leaders}

1. Do you enjoy having lay person assist and involved in leading the worship service? $($ ) Very often ( ) Often ( ) Occasionally ( ) Seldom ( ) Never

How often?

( ) Once a month

( ) Twice a month

( ) Three times a month

( ) Every week

( ) Less then once a month

2. Rank from 1 to 5 in the order of your preference the following categories of worship leaders:

- Youth

_ Young students

— Women

- Children

— Men

3. Is there any category of leader who has failed to lead you effectively in worship?

( ) Yes

( ) No

( ) Undecided

If yes, which?

\section{Ordinances}

1. Can you see the baptismal service?
( ) Yes
( ) No

2. Can you hear the baptismal service?
( ) Yes
( ) No

3. Do you like the use of the pitcher, cup, and loaf to dramatize the first Lord's Supper?

( ) Very often ( ) Often ( ) Occasionally ( ) Seldom ( ) Never

4. Can you hear the minister during the Lord's Supper serving?

$($ ) Very often ( ) Often ( ) Occasionally ( ) Seldom ( ) Never

5. Throughout the year during the celebration of the Lord's Supper,

a. Do you find meaning in a candlelight service?

( ) Very often ( ) Often ( ) Occasionally ( ) Seldom ( ) Never

b. Do you find meaning in a Sabbath morning Lord's Supper observance?

( ) Very often ( ) Often ( ) Occasionally ( ) Seldom ( ) Never 
c. Do you find meaning in celebrating baptism and the Lord's Supper in the same service?

( ) Very often ( ) Often ( ) Occasionally ( ) Seldom ( ) Never

d. Do you like instrumental music while you are being served the Lord's Supper?

( ) Very often ( ) Often ( ) Occasionally ( ) Seldom ( ) Never

e. Do you like a silent Lord's Supper?

( ) Very often ( ) Often ( ) Occasionally ( ) Seldom ( ) Never

6. Do you understand the meaning of
a. Baptism
Yes No
b. Lord's Supper
Yes No
c. Ordinance of Foot-Washing
Yes No
d. Bread and Wine ordinance
Yes No

Would you like to be better informed about the meaning of these ordinances?

\section{Sermon}

1. Do you think a sufficient variety of topics is dealt with?
( ) Yes
( ) No
( ) Undecided

2. Do you feel that the length of the sermon is appropriate?
( ) Yes
( ) No
( ) Undecided

3. Do you feel the explanation of the biblical text is adequate and enlightening?

( ) Very often ( ) Often ( ) Occasionally ( ) Seldom ( ) Never

4. Is there a favorite sermon you have heard in the last two years you would like to have repeated?
a. ( ) Yes ( ) No
b. If yes, what was the title or the topic?

5. Do you like a series of message?
( ) Yes
( ) No
( ) Undecided

6. Is there a text, topic, or sermon series you would like to hear preached?
a. ( ) Yes ( ) No ( ) Undecided
b. If yes, please indicate: 
7. Would you like regular opportunities for talk-back and discussion of the sermon?
a. ( ) Yes
( ) No
( ) Undecided
b. If yes, please check when:
( ) After the worship service on Sabbath morning
( ) Sabbath afternoon after potluck
( ) Some week evening. Your preference:

8. Below are several areas involved in presenting the sermon. Check any that you feel needs to be improved by the preacher.
( ) Eye contact
( ) Speed of speech
( ) Gesture
( ) Variation in tone of voice
( ) Use of notes
( ) Volume of speech
( ) Grammar
( ) Movement of hands or feet

9. Do you like the children's moment?
a. ( ) Yes ( ) No ( ) Undecided
b. How long do you feel it should be?
( ) Less than 3 minutes
( ) About 3 minutes
( ) More than 3 minutes

c. How often would you prefer the children's moment?
( ) Weekly
( ) Once in 3 weeks
( ) Twice a month
( ) Once a month

d. Would you prefer the children to sit at the front of the sanctuary during the children's moment?
( ) Yes
( ) No
( ) Undecided

10. Does the children's/youth moment create in you the desire for spending more time at home in family worship?

Very little Little Some Much Very much

11. Have you found meaning in the varied forms of proclamation used such as drama, video, slides, dramatic musicals, dramatic readings, and computer graphics?

1. ( ) Very often ( ) Often ( ) Occasionally ( ) Seldom ( ) Never 
2. Rank from 1 to 6 your order of preference:
( ) Drama
( ) Dramatic musicals
( ) Slides
( ) Dramatic readings
( ) Video
( ) Computer graphics/power point presentation

12. In which ways does the sermon encourage you for a deeper encounter with God and new commitments in your life?

\section{Participation in Worship}

1. Theoretically you are expected to participate in worship in several areas. Do you feel a sense of participation? Circle your response.

a. In the organ/piano music?

Very little Little Some Much Very much

b. In the other musical instruments? Which one:

Very little Little Some Much Very much

c. In the hymns?

Very little Little Some Much Very much

d. In the prayer?

Very little Little Some Much Very much

e. In the choral/group music?

Very little Little Some . Much Very much

f. In the Scripture reading?

Very little Little Some Much Very much

g. In the preaching/sermon?

Very little Little Some Much Very much

h. In the children's moment?

Very little Little Some Much Very much

2. "When you come to church, you should forget for a time the problems and responsibilities you have to deal with all week."

Would you agree with this statement?

Strongly agree

Undecided

Agree

Disagree

Strongly disagree 
3. How much of a direct connection or relationship do you see between what you do during the week and what you hear and do during worship service on Sabbath? Very little Little Some Much Very much

4. In the responsibilities, problems, or decisions which you face in your work (or home or social life), do you ask yourself what the religious perspective or Christian answer is for that particular situation?

( ) Very often ( ) Often ( ) Occasionally ( ) Seldom ( ) Never

\section{Welcome and Announcements}

1. Do you prefer that the worshipers be welcomed and visitors recognized?
( ) Yes
( ) No
( ) Undecided

2. Can you hear the names of the new members presented and the announcements made?
( ) Yes
( ) No
( ) Most of the time
( ) Seldom

3. Do you think the close of the worship period is the best time for important announcements?
( ) Yes
( ) No
( ) Undecided

If no, when would you prefer that this be done?

\section{Sound System}

1. Are you able to easily hear those who speak from the pulpit? Circle one response.
Always
Often Sometimes
Seldom
Never

2. If you are unable to hear most speakers,

a. Which speaker can you not hear?

Minister Elder Teacher Lay person

b. Do you wear a hearing aid?

Yes No

c. Would you use a hand-held hearing set if it were installed where you sit? Yes No Undecided

d. Would you move to designated seats in the sanctuary if hearings sets were installed there?

Yes No Undecided 


\section{8}

e. Where do you usually sit?
( ) Left
( ) Under left balcony
( ) Under middle balcony
( ) Middle
( ) Under right balcony
( ) Left balcony
( ) Right
( ) Right balcony
( ) Middle balcony

\section{Extra Comments}

Use this space and the back of this page to indicate any other suggestions or questions on our worship service. Please return this survey to any church leader as soon as possible. 
APPENDIX C

WORSHIP INVENTORY SURVEY 


\section{WORSHIP INVENTORY SURVEY}

Age: __ Sex: M $\quad$ F A Church Member? $\quad$ Y N Now Long?

1. The high point of the worship service for me is:

a. Morning prayer

b. Special music

c. Scripture reading

d. Sermon

e. Invitation

g. Congregational singing

h. Other:

2. Which of the following types of worship service would you prefer:
a. Very formal
b. Restrained, but not too formal
c. More spontaneous and less structured
d. Very informal and unstructured

3. I prefer a sermon that:
a. Is highly evangelistic
b. Relates Scripture to everyday problems
c. Is based on personal illustration from the pastor
d. Explains a Scripture passage
e. Is based on real people experiences

4. How long do you believe a sermon should be?

5. Which type of music do you prefer in a worship service?
a. Old familiar hymns
b. New catchy tunes
c. Folk music
d. Choir anthems
e. Solo

6. Do you feel that dramatic presentations help you to worship? Yes No Sometimes

7. Do announcements detract from worship? Yes No Sometimes 
8. If you could, what one thing would you change in the worship service of your church?

9. What do you feel should be the strongest mood of theme in a worship service?
a. Laughter
b. Thanksgiving
c. Assurance
d. Joy
e. Seriousness
f. Commitment
g. Hope
h. Surrender

10. Would you prefer to have regular Worship Services that separate youth from adults?

Yes No Occasionally

11. When new elements are introduced in a worship service (guitars instead of organ, dialogue or testimony instead of sermon; drama; soundtrack instead of live accompaniment; or any change from the regular service) what is your reaction?

12. Do you like sermons that are obviously directed toward you (family, youth, divorce, vocation, dating, addiction, and so forth)?

Yes No Occasionally

13. What subjects would you like to hear discussed?

14. Would you like for the pastor to preach occasionally on topics suggested by youth or any other minority groups in your church?

Yes No Occasionally

15. Do adults in your church encourage youth to participate in the leadership of worship services?

Yes No Occasionally

16. What is your favorite song for use in worship? 
17. Consider the meaning of the words of the following songs, and number them in order of their significance for you in worship.

_ In the Garden

_ One in the Spirit

_ Take My Life and Let It Be

- Holy, Holy, Holy

- How Great Thou Art

- A Mighty Fortress

_ At the Cross

— More About Jesus

18. Listed below are a few of the many types of music used in worship today. Circle the types most significant to you and explain why.

a. Major works, such as Handel's Messiah

b. Formal anthems, such as settings of scriptural texts

c. Folk musicals, such as Good News

d. Anthems that are hymn arrangements

e. Gospel songs, such as "Love lifted Me"

f. Choruses, such as "Majesty", "Give Thanks" and "Holy Ground"

g. Spirituals, such as "He's Got the Whole World in His Hand"

19. What do you usually do during the morning worship service?

20. The greatest problem I am facing just now is:

21. What do you do in order to help you worship in private (Bible reading, prayer, meditation, and so forth)?

22. When I listen to the preaching, I am:

a. Interested most of the time

b. Bored most of the time because I usually don't listen

- The sermon is not relevant to me most of the time

— I'd rather be somewhere else

- I honestly don't understand what's being said most of the time

— Other: 
23. The offering is part of the worship service because:
a. The church needs the money to pay bills
b. Is my obligation to give
c. The Bible says we should give
d. It gives me opportunity to give something of myself to God.

24. When other people lead in prayer, I:
a. Listen to the words and participate silently in the prayer to make it mine also
b. Feel close to God and enjoy the experience
c. Think of other things
d. Listen to the prayer but don't know what to do or what to concentrate on
e. Other:

25. When I participate in the Lord's Supper or Communion, I:
a. Understand its meaning
b. Consider it routine; I don't really understand it
c. Enjoy the reverent atmosphere
d. Feel the presence of Christ in a special way
e. Other:

26. When the Bible is read in a worship service, I:
a. Don't pay much attention
b. Listen for the meaning of the passage
c. Read along silently in personal Bible or pew Bible
d. Consider it a meaningful part of the worship for me
e. Other comments:

27. I read the Bible for private worship:
a. Never
b. Sometimes
c. On a regular basis

28. Meaningful characteristics of worship for me are:

_ Service to others

- Praising God

_ Talking about religion with friends

— Feeling forgiven

- Being quiet

- Praying

- Singing

— Being with friends

— Speaking to God

- Listening to God

— Going forward during the invitation

- Giving money

- Listening to the preacher

Other:

29. I really feel God's presence most when (consider any time - public or private): 
APPENDIX D

WORSHIP EXPERIENCE QUESTIONNAIRE 


\section{WORSHIP EXPERIENCE QUESTIONNAIRE}

We are honored that you chose to worship with us. It is for people like you that this church exists. Please candidly answer the questions below based on your worship experience with us.

In our endeavor to provide you with a satisfactory corporate worship experience:

1. What are three things that we do well now which you want us to keep doing/providing?

2. What are three things that we do now which you would like to see us stop doing/providing?

3. What are three things that we don't do now which you would like us to start doing/providing?

4. How do you feel we compare with other churches' worship services you attended?

5. What are some of the trends in your spiritual life that you feel we need to know to help you connect better with God? 
APPENDIX E

WORSHIP SURVEY SAMPLE LATTER 
Dear Worshiper,

We want to provide better worship service to you! In order to help us determine where to focus our worship continuous improvement efforts, we would like you to complete this Worship Inventory Survey (or the Worship Questionnaire).

We are sending the same survey to all our worshipers.

Too often, we get asked to complete surveys and the results are never shared with the worshipers who provided the feedback in the first place. You have our commitment that we will share the results of this survey with you, and more important, our worship service improvement plans based on your feedback.

Please take the time to complete the survey and return it in the envelop provided by (date). Your input is very much appreciated.

Sincerely, 


\section{APPENDIX F}

WORSHIP PLANNING WORKSHEET 


\section{WORSHIP PLANNING WORKSHEET}

Date:

Worship Theme:

Message Title:

Text:

Piano/Keyboard:

Organ:

Children's Moment:

Worship Leader:

Overhead Projector Operator:

Exaltation Songs:

1.

2 .

3.

4.

Special Music:

Person:

Song:

Closing Song or Special:

As a result of this service, what do we want the worshipers to:

a. Believe about God:

b. Feel in their hearts?

c. Do?

Special Notes: 
APPENDIX G

WORSHIP EVALUATION FOR THE LEADERS 


\section{WORSHIP EVALUATION FOR THE LEADERS}

Check one for each question:

1. Is the main effort of the worship we lead to entertain the congregation?

Yes No Uncertain

2. Do the worship leaders view themselves as the only performers?

Yes No Uncertain

3. Are the lay people involved in planning the worship experience?

Yes No Uncertain

4. Are the lay people involved in leading the worship service?

Yes No Uncertain

5. Are the worshipers directed in a specific encounter with God?

Yes No Uncertain

6. Is the Bible reading and interpretation central in worship?

Yes No Uncertain

7. Is there variety in the format of worship?

Yes No Uncertain

8. Do the hymns and songs provide accurate biblical interpretation?

Yes No Uncertain

9. Are the worshipers allowed to participate in worship other than by singing or listening?

Yes No Uncertain

10. Is there significant variety and change in the various elements of worship?

Yes No Uncertain

11. How much time is spent weekly in designing the worship service?

$1 / 2$ to 1 hour. $\quad 1$ to 3 hours. $\quad 4$ to 8 hours.

12. How important is worship to the church?

Very Moderate Little 
APPENDIX $\mathrm{H}$

WORSHIP SERVICE EVALUATION 


\section{WORSHIP SERVICE EVALUATION}

The purpose of this evaluation is to discover ways to improve the church worship service. After observing a service, answer the questions below based on that one service. The numbers under each question indicate varying degrees of effectiveness: 0 - for very poor, 1 - for poor, 2 - for fair, 3 - for good, 4 - for very good, and 5 - for excellent. Circle the number which, in your opinion, describes best your answer in each instance. After each rating, if you desire, list factors which determined your choice:

1. Was the meeting place conducive to worship?

$$
\begin{array}{llllll}
0 & 1 & 2 & 3 & 4 & 5
\end{array}
$$

2. Did the ushers contribute to the worshipfulness of the service?

$$
\begin{array}{llllll}
0 & 1 & 2 & 3 & 4 & 5
\end{array}
$$

3. Were the worship leaders prepared to lead when the service started?

$$
\begin{array}{llllll}
0 & 1 & 2 & 3 & 4 & 5
\end{array}
$$

4. Was an appropriate selection and arrangement/order of worship elements used in the service?

$\begin{array}{llllll}0 & 1 & 2 & 3 & 4 & 5\end{array}$

5. Where the hymns appropriate?

$\begin{array}{llllll}0 & 1 & 2 & 3 & 4 & 5\end{array}$

6. Did the congregational participate in the singing in a meaningfully way?

$$
\begin{array}{lllllll}
0 & 1 & 2 & 3 & 4 & 5
\end{array}
$$

7. Did the musicians, choir members, singers, and leader refrain from anything that would distract the worshipers?
0
12
34
5

8. Did the musical instruments contribute meaningfully to your worship experience?

$$
\begin{array}{llllll}
0 & 1 & 2 & 3 & 4 & 5
\end{array}
$$

9. Was the public prayer helpfuil to you?

$$
\begin{array}{llllll}
0 & 1 & 2 & 3 & 4 & 5
\end{array}
$$

10. Was the Bible handled appropriately? Was the Scripture passage read effectively?

$\begin{array}{llllll}0 & 1 & 2 & 3 & 4 & 5\end{array}$


11. Did the offertory present an opportunity for worshipful expression? $\begin{array}{llllll}0 & 1 & 2 & 3 & 4 & 5\end{array}$

12. Did the "special" music contribute effectively to meaningful worship? $\begin{array}{llllll}0 & 1 & 2 & 3 & 4 & 5\end{array}$

13. Did God seem real to you?

$$
\begin{array}{llllll}
0 & 1 & 2 & 3 & 4 & 5
\end{array}
$$

14. Did you worship reverently without distraction?

$$
\begin{array}{llllll}
0 & 1 & 2 & 3 & 4 & 5
\end{array}
$$

15. Was there evidence of a sense of purpose and direction in the worship?

$$
\begin{array}{llllll}
0 & 1 & 2 & 3 & 4 & 5
\end{array}
$$

16. Did you feel interested in the sermon?

$\begin{array}{llllll}0 & 1 & 2 & 3 & 4 & 5\end{array}$

17. Did the sermon give you new information?

$\begin{array}{llllll}0 & 1 & 2 & 3 & 4 & 5\end{array}$

18. Did the sermon inspire you to action?

$\begin{array}{llllll}0 & 1 & 2 & 3 & 4 & 5\end{array}$

19. Did the call/invitation seem appropriate and effective?

$\begin{array}{llllll}0 & 1 & 2 & 3 & 4 & 5\end{array}$

20. Did you respond to the call/invitation in any way?

$\begin{array}{llllll}0 & 1 & 2 & 3 & 4 & 5\end{array}$

21. In what specific ways was the Father, Son, and Holy Spirit triune nature of God expressed in the service?

22. Was the story of God's work in history adequately expressed?

Was the Good News expressed?

The relationship between heaven and earth was expressed?

23. How did this service help the worshipers identify their dislocation? How did worship relocate the worshiper in God? The worship planned interface with the needs of people present? 
24. Where did this worship create the feelings of aware and wonder in the worshiper?

25. In this worship, where were the following experienced:

Intention -

Imagination -

Contemplation -

Celebration -

Commitment -

Body expression -

26. What was your overall response to the worship experience?

27. What impressed you most favorably?

28. What improvements would you suggest?

29. Did your encounter with God during the worship experience impress you to make changes in your
a. Personal life
b. Relationships
Yes No
c. Behavior and Lifestyle
Yes No
d. Family life
Yes No
e. Spiritual discipline
Yes No
Yes No

30. In the worship service have you been reminded of the meaning of
a. The assurance of salvation through the ministry of Jesus in heaven
b. The joy of the Sabbath experience
Yes No
c. The hope in the Second Coming of Jesus
Yes No
Yes No 
APPENDIX I

MY ENCOUNTER WITH GOD 


\section{MY ENCOUNTER WITH GOD}

1. How did the worship service appeal to your
a. Mind?
b. Emotions?
c. Will?

2. Are there any changes that you decided to make in your life as a result of your presence in the worship service?

3. In which ways were you encouraged to make new commitments as a result of your encounter with God?

4. How did the worship experience bring you into oneness with other worshipers?

5. In what ways did the worship service encourage you for a positive change toward God?

6. To what extent and in what ways was the grace of God evident for you in the worship service?

7. In what ways was the hope and preparation for the second coming of Jesus a challenge for you in the worship service?

8. In what ways did your confidence in Jesus' interceding for you in the heavenly sanctuary help you to renew your assurance of salvation?

9. What is your understanding of:

a. Worship in general

b. SDA worship 
c. Genuine encounter with God

d. Sabbath experience

e. Hope of the Second Coming of Jesus

f. Ministry of Christ in the Sanctuary

10. Did your encounter with God during the worship experience impress you to make changes in your
a. Personal life
Yes No
b. Relationships
Yes No
c. Behavior and Lifestyle
Yes No
d. Family life
Yes No
e. Spiritual discipline
Yes No

11. In the worship service have you been reminded of the meaning of

a. The assurance of salvation through the ministry of Jesus in heaven Yes No

b. The joy of the Sabbath experience Yes No

c. The hope in the Second Coming of Jesus Yes No

12. Did the Scripture readings remind you of any of these SDA beliefs? Yes No

13. Did the singing remind you of these SDA beliefs and bring relevance to your life? Very little Little Some Much Very much

14. Did the congregational readings motivate you to spend more time in private Scripture reading? Yes No

15. Did the moments of prayer in church motivate you to a more active personal prayer life? Yes No

16. Do you understand the meaning of
a. Baptism
Yes No
b. Lord's Supper
Yes No
c. Ordinance of Foot-Washing Yes No
d. Bread and Wine ordinance Yes No

Would you like to be better informed about the meaning of these ordinances?

17. Did the children's/youth moment create in you the desire for spending more time at home in family worship?

Very little Little Some Much Very much 


\section{BIBLIOGRAPHY}

Archer, David. "The Postmodern Challenge to Worship." Epworth Review, April 2000, 613.

Arn, Charles. How to Start a New Service: Your Church Can Reach New People. Grand Rapids, MI: Baker Books, 1997.

Baggett, Byrd. The Book of Excellence. Nashville, TN: Rutledge Hill Press, 1992.

Barna, George. The Habits of Highly Effective Churches. Ventura, CA: Regal Books, 1999.

Basden, Paul. The Worship Maze: Finding a Style to Fit Your Church. Downers Grove, IL: InterVarsity Press, 1999.

Beausay, William. The People Skills of Jesus. Nashville, TN: Thomas Nelson, 1997.

Berkley, James D., ed. Leadership Handbook of Management and Administration. Grand Rapids, MI: Baker, 1997. , ed. Leadership Handbook of Preaching and Worship. Grand Rapids, MI: Baker Books, 1992.

Bietz, Gordon. "Religion for the Head and Heart." Adventist Review, 8 January 1998.

Birch, Alf. "What Is Worship?" Record [South Pacific Division], June 1991, 4.

Black, Kathy. Worship across Cultures: A Handbook. Nashville, TN: Abingdon Press, 1998.

Bonn, Linda. The Work of the Worship Committee. Valley Forge, PA: Judson Press, 1998.

Brauer, James L. "The Role of Music in Seeker Services." Concordia Journal 24 (1998): 7-20.

Burrill, Russell. Revolution in the Church. Fallbrook, CA: Hart Research Center, 1993. 
Calkins, Ann, and Jack Calkins. Children in Worship. Lincoln, NE: AdventSource, 1998.

Calkins, Jack. Children's Church: Responding to God's Love. Lincoln, NE: AdventSource, 1999.

Callahan, Kennon L. Dynamic Worship: Mission, Grace, Praise, and Power. San Francisco, CA: HarperSanFrancisco, 1994.

Carney, Michael. "Liturgical Music in the Postmodern Age." Hymn 50 (1999): 15-23.

Carson, D. A. Worship: Adoration and Action. Grand Rapids, MI: Baker Book House, 1993.

Carson, Timothy. So You're Thinking About Contemporary Worship. St. Louis, MO: Chalice Press, 1997.

Clark, Kenneth E., and Mirian B. Clark. Choosing to Lead. Charlotte, NC: Iron Gate, 1994.

Coleman, Robert. The Master Plan of Evangelism. Westwood, NJ: Advocate, 1990.

Cousins, Don, Leith Anderson, and Arthur DeKruyter. Mastering Church Management. Portland, OR: Multnomah Press, 1990.

Covey, Stephen R. Principle Centered Leadership. New York, NY: Fireside, 1992.

Dingwall, Cindy. Worship Time with Kids : Bible-Based Activities for Children's Church. Nashville, TN: Abingdon, 1998.

Dobson, Edward G. Starting a Seeker Sensitive Service. Grand Rapids, MI: Zondervan, 1993.

Dudley, Roger L. Why Our Teenagers Leave the Church. Hagerstown, MD: Review and Herald, 2000.

Dugmore, C. W. The Influence of the Synagogue Upon the Divine Office. Westminster: Faith Press, 1964.

Engle, Paul E. Baker's Worship Handbook: Traditional and Contemporary Service Resources. Grand Rapids, MI: Baker Books, 1998.

Foley, Edward, and Mark Paul Bangert. Worship Music: A Concise Dictionary. Collegeville, MN: Liturgical Press, 2000. 
Frame, John M. Worship in Spirit and Truth. Phillipsburg, NJ: P\&R Pub., 1996.

Freudenburg, Ben, and Rick Lawrence. The Family Friendly Church. Loveland, CO: Group Publishing, 1998.

Fulton, Roger. Common Sense Leadership. New York, NY: Barnes \& Noble, 2001.

Gaddy, C. Welton, and Don W. Nixon. Worship, a Symphony for the Senses. Macon, GA: Smyth \& Helwys Pub., 1998.

Gangel, Kenneth O. Team Leadership in Christian Ministry. Rev. ed. Chicago, IL: Moody Press, 1997.

Gangel, Kenneth O., and Jim Wilhoit. The Christian Educator's Handbook on Spiritual Formation. Grand Rapids, MI: Baker Books, 1997.

Garlington, Joseph L. Worship: The Pattern of Things in Heaven. Shippensburg, PA: Destiny Image, 1997.

General Conference of Seventh-day Adventists. Seventh-day Adventist Church Manual. 16th ed. Hagerstown, MD: Review and Herald, 2000. . Seventh-day Adventist Elder's Handbook. Washington, DC: Author, 1994. . Seventh-day Adventist Minister's Handbook. Washington, DC: Author, 1997. . Seventh-day Adventists Believe. Washington, DC: Author, 1988.

George, Carl F. Prepare Your Church for the Future. Grand Rapids, MI: Fleming H. Revell, 1992.

George, Carl F., and Robert F. Logan. Leading and Managing Your Church. Grand Rapids, MI: Fleming H. Revell, 1996.

Gillespie, V. Bailey. The Sounds of Grace in Our Churches. Riverside, CA: Hancock Center Publications, 1996.

Graybill, Ronald D. "Enthusiasm in Early Adventist Worship." Ministry, October 1991.

Habecker, Eugene B. Leading with a Follower's Heart. Wheaton, IL: Victor Books, 1990. 
Hare, Doreen C. "Worship Fit for the Third Millennium." Epworth Review, April 2000, 14-17.

Hayford, Jack. Worship His Majesty. Rev. and exp. ed. Ventura, CA: Regal Books, 2000.

Hendricks, Howard G. Color Outside the Lines. Nashville, TN: Word Publishing, 1998.

Hendricksen, William. 1-2 Timothy and Titus: New Testament Commentary. Grand Rapids: Baker, 1957.

Henry, Matthew. A Commentary on the Bible. New York, NY: Funk and Wagnalls, n.d.

Hill, Andrew E. Enter His Courts with Praise. Grand Rapids, MI: Baker Books, 1993.

Hodges, Randy T. A Call to Worship. Kansas City, MO: Beacon Hill Press, 1996.

Holmes, C. Raymond. Sing a New Song! Berrien Springs, MI: Andrews University Press, 1984.

Holmes, C. Raymond, and Douglas Kilcher. The Adventist Minister. Berrien Springs, MI: Andrews University Press, 1991.

Hooper, Wayne. "Inspire Your Congregation's Singing." Ministry, April 1990, 12-13.

Hudson, Jill M. Evaluating Ministry: Principles and Processes for Clergy and Congregations. Washington, DC: Alban Institute, 1992.

Humphrey, Art, and Patricia L. Humphrey. "I Have a Hard Time Staying Awake in Church." Guide, 10 November 2001, 13.

Hunter, George G. Church for the Unchurched. Nashville, TN: Abingdon Press, 1996.

Hustad, Donald. True Worship: Reclaiming the Wonder \& Majesty. Carol Stream, IL: Hope Publ., 1998.

Hybels, Lynne, and Bill Hybels. Rediscovering Church: The Story and Vision of Willow Creek Community Church. Grand Rapids, MI: Zondervan, 1995.

Integrity Music Inc. Worship Software. Seventh-day Adventist version ed. Mobile, AL: Integrity Music, 1996.

Jasper, Tony, and Pauline Webb. Worship in Every Event: Worship Resources for Every Day. Oxford: Oxford University Press, 1998. 
Johansson, Calvin M. Discipling Music Ministry: Twenty-First Century Directions. Peabody, MA: Hendrickson Publishers, 1992.

Jones, Laurie Beth. Jesus, CEO: Using Ancient Wisdom for Visionary Leadership. New York, NY: Hyperion, 1995. . Jesus, Inc.: The Visionary Path. New York, NY: Crown Business, 2001.

Kahn, Si. Organizing. Silver Spring, MD: National Association of Social Workers Press, 1991.

Kavanaugh, Patrick. Worship: A Way of Life. Grand Rapids, MI: Chosen Books, 2001.

Kraeuter, Tom. Developing an Effective Worship Ministry. Lynnwood, WA: Emerald Books, 1993.

. Keys to Becoming an Effective Worship Leader. Hillsboro, MO: Training Resources, 1991.

. The Worship Leader's Handbook. Lynnwood, WA: Emerald Books, 1997.

Leadingham, Everett. Worshiping God: The Church's First Call. The Dialog Series. Kansas City, MO: Beacon Hill, 1996.

Lewis, Phillip V. Transformational Leadership. Nashville, TN: Broadman \& Holman Publishers, 1996.

Liesch, Barry. The New Worship : Straight Talk on Music and the Church. Exp. ed. Grand Rapids, MI: Baker Books, 2001.

Maddox, Mirian B. Dramatized Bible Readings. Grand Rapids, MI: Baker House, 1980.

Malphurs, Aubrey. Planting Growing Churches for the 21st Century. Grand Rapids, MI: Baker Books, 1995. 1993.

Pouring New Wine into Old Wineskins. Grand Rapids, MI: Baker Books,

Marshall, Don R. The Four Elements of Successful Management: Select, Direct, Evaluate, Reward. New York, NY: Amacom, 1999.

Martin, Ralph P. Worship in the Early Church. Grand Rapids, MI: Eerdmans Publishing, 1992. 
Maxwell, John C. Developing the Leaders around You. Nashville, TN: Thomas Nelson, 1995.

. The 21 Irrefutable Laws of Leadership. Nashville, TN: Thomas Nelson Publishers, 1998.

. Failing Forward: Turning Mistakes into Stepping Stones for Success.

Nashville, TN: Thomas Nelson, 2000.

. Success: One Day at a Time. Nashville, TN: Countryman, 2000.

Maxwell, John C., and Tim Elmore. The Power of Partnership in the Church. Nashville, TN: Countryman, 1999.

McLaren, Brian D. Reinventing Your Church. Grand Rapids, MI: Zondervan, 1998.

Miller, Steve. The Contemporary Christian Music Debate. Wheaton, IL: Tyndale House, 1993.

Mittelberg, Mark. Building a Contagious Church. Grand Rapids, MI: Zondervan, 2000.

Morey, Robert A. Worship: It's Not Just Sunday Morning. Iowa Falls, IA: World Bible Publishers, 2001.

Morgenthaler, Sally. Worship Evangelism: Inviting Unbelievers into the Presence of God. Grand Rapids, MI: Zondervan Publishing House, 1995.

Nelson, Alan, and Gene Appel. How to Change Your Church without Killing It. Nashville, TN: Word Publishing, 2000.

Norton, Ricardo. Syllabus for CHMN 664, Equipping Lay Leaders for Church Growth. Andrews University, Berrien Springs, MI, 1997.

Old, Hughes Oliphant. The Reading and Preaching of the Scriptures in the Worship of the Christian Church. Grand Rapids, MI: Eerdmans, 1998.

Olivetto, Washington. Seminar in "Building Quality into Your Organization." Sao Paulo, SP, Brazil, May 1992.

Ortlund, Anne. Up with Worship. Rev. and updated ed. Nashville, TN: Broadman \& Holman, 2001. 
Ostring, Sven. "Notes on Worship." Record (South Pacific Division), 19 January 2002, 10.

Owens, Ron, and Jan McMurray. Return to Worship: A God-Centered Approach. Nashville, TN: Broadman \& Holman, 1999.

Pankake, Anita M. Implementation: Making Things Happen. The School Leadership Library. Larchmont, NY: Eye on Education, 1998.

Perry, Michael, ed. The Dramatized New Testament. Grand Rapids, MI: Baker House, 1994. , ed. The Dramatized Old Testament. Grand Rapids, MI: Baker House, 1995.

Ray, David R. The Big Small Church Book. Cleveland, OH: Pilgrim Press, 1992. .Wonderful Worship in Small Churches. Cleveland, OH: Pilgrin Press, 2000.

Roberts, Harry V., and Bernard F. Sergesketter. Quality Is Personal: A Foundation for Total Quality Management. New York, NY: Free Press, 1993.

Rossi, Peter Henry, Howard E. Freeman, and Mark W. Lipsey. Evaluation: A Systematic Approach. 6th ed. Thousand Oaks, CA: Sage Publications, 1999.

Saliers, Don E. Worship as Theology: Foretaste of Glory Divine. Nashville, TN: Abingdon Press, 1994. . Worship Come to Its Senses. Nashville, TN: Abingdon Press, 1996.

Saxe, John Godfrey. "The Blind Men and the Elephant," quoted in Henry Mintzberg, "Strategy Formation: Schools of Thought," in Perspectives on Strategic Management, ed. James W. Fredrickson. New York: Harper Business Division of Harper \& Row, 1990.

Schwarz, Christian A., and Christoph Schalk. Implementation Guide to Natural Church Development. Carol Stream, IL: ChurchSmart Resources, 1998.

Segler, Franklin M. Christian Worship. Nashville, TN: Broadman \& Holman Publishers, 1996.

. Understanding, Preparing for, and Practicing Christian Worship. 2d ed. Nashville, TN: Broadman \& Holman Publishers, 1996. 
Shipley, Joseph T. Dictionary of Word Origins. New York, NY: Philosophical Library, 1945.

Stookey, Laurence Hull. Let the Whole Church Say Amen!: A Guide for Those Who Pray in Public. Nashville, TN: Abingdon Press, 2001.

Towns, Elmer L. Putting an End to Worship Wars. Nashville, TN: Broadman \& Holman Publishers, 1997.

Townsend, Michael J. Worship: Thinking Things Through. Peterborough: Epworth Press, 1997.

Tozer, A. W. Worship : The Missing Jewel. Harrisburg, PA: Christian Publications, 1992.

Ward, Elaine M. Asking for Wonder: "Resources" for Creative Worship and Preaching. Lima, OH: CSS Publ., 1997.

Wardle, Terry Howard. Exalt Him! Camp Hill, PA: Christian Publications, 1988.

Webber, Robert. The Biblical Foundations of Christian Worship. Peabody, MA: Hendrickson Publishers, 1993.

. Blended Worship: Achieving Substance and Relevance in Worship. Peabody, MA: Hendrickson Publishers, 1996.

. Learning to Worship with All Your Heart: A Study in the Biblical Foundations of Christian Worship. Peabody, MA: Hendrickson, 1996.

. Planning Blended Worship. Nashville, TN: Abingdon Press, 1998.

. Rediscovering the Missing Jewel: A Study of Worship through the Centuries. Peabody, MA: Hendrickson, 1996.

.Worship Is a Verb: Eight Principles for Transforming Worship. 2nd ed.

Peabody, MA: Hendrickson Publishers, 1992.

.Worship Old \& New: A Biblical, Historical, and Practical Introduction. Rev. ed. Grand Rapids, MI: Zondervan, 1994.

. The Worship Phenomenon. Nashville, TN: Abbot Martyn, 1994.

Webber, Robert, ed. The Complete Library of Christian Worship. 7 vols. Nashville, TN: Star Song Publishing House Group, 1994. 
Webber, Robert, ed. Music and the Arts in Christian Worship. Vol. 4 of The Complete Library of Christian Worship. Nashville: Star Song Pub. Group, 1994.

Webster's New Collegiate Dictionary. Springfield, MA: Merrian-Webster, 1974.

Whaley, Vernon M. The Dynamics of Corporate Worship. Ministry Dynamics for a New

Century, ed. Warren W. Wiersbe. Grand Rapids, MI: Baker Books, 2001.

White, Ellen G. The Acts of the Apostles. Mountain View, CA: Pacific Press, 1911. $1890,145-6$.

. "Christ Prayed for Unity among His Disciples." Review and Herald, 11 March

. "Co-Operation with Ministers." Review and Herald, 24 July 1883, 465-6.

. The Desire of Ages. Mountain View, CA: Pacific Press, 1940.

. Education. Oakland, CA: Pacific Press, 1903.

. Evangelism. Washington, DC: Review and Herald, 1970.

. The Historical Sketches of the Foreign Missions of the Seventh-day

Adventists. Basle: Imprimerie Polyglotte, 1886.

. The Ministry of Healing. Mountain View, CA: Pacific Press, 1942.

. MS 24, 1887, Ellen G. White Research Center, Andrews University, Berrien Springs, MI.

. My Life Today. Washington, DC: Review and Herald, 1952.

. "The New Heart." Review and Herald, 14 April 1885, 225-6.

. "Our Late Experience." Review and Herald, 27 February 1866, 97-99.

. Pastoral Ministry. Silver Spring, MD: General Conference of Seventh-day Adventists, 1995.

. Patriarchs and Prophets. Washington, DC: Review and Herald, 1958.

. "Remarks by Mrs. E. G. White, at the Tent-Meeting in Oakland, July 2, 1869." Review and Herald, 17 August 1869, 57-58. 
White, Ellen G. "Requisites to a Good Prayer-Meeting." Signs of the Times, 4 December 1884,475 .

"Sabbath Reform Needed." Review and Herald, 18 March 1884, 177-8.

. "The Schools of the Prophets." The Signs of the Times, 22 June 1882, 277-8.

. Testimonies for the Church. 9 vols. Mountain View, CA: Pacific Press, 1948.

. Testimonies to Ministers and Gospel Workers. Mountain View, CA: Pacific

Press, 1923.

. "To the Brethren and Sisters." Review and Herald, 10 June 1852, 21.

. The Voice in Speech and Song. Boise, ID: Pacific Press, 1988.

White, James F. A Brief History of Christian Worship. Nashville, TN: Abingdon Press, 1993.

. Documents of Christian Worship: Descriptive and Interpretive Sources.

Louisville, KE: Westminster/John Knox Press, 1992.

. Rethinking the Church. Grand Rapids, MI: Baker Books, 1997.

Whitney, Donald S. Spiritual Disciplines within the Church: Participating Fully in the Body of Christ. Chicago, IL: Moody, 1996.

Wicai, Hillary. "Postmodern Worship, Three Views." Congregations, July/August 2001, 28-30.

Wiersbe, Warren W. Real Worship. 2nd ed. Grand Rapids, MI: Baker, 2000.

Williams, Dennis E., and Kenneth O. Gangel. Volunteers for Today's Church. Grand Rapids, MI: Baker Books, 1993.

Woods, Charles Jeffrey. User Friendly Evaluation: Improving the Work of Pastors, Programs, and Laity C. Jeff Woods. Washington, DC: Alban Institute, 1995.

Wright, N. T. For All God's Worth: True Worship and the Calling of the Church. Grand Rapids, MI: Eerdmans, 1997.

Wright, Tim, and Herb Miller. A Community of Joy: How to Create Contemporary Worship Effective Church Series. Nashville, TN: Abingdon Press, 1994. 
Wright, Tim, and Jan Wright. Contemporary Worship: A Source Book for SpiritualTraditional, Praise and Seeker Services. Nashville, TN: Abingdon Press, 1997.

Zigarelli, Michael A. Management by Proverbs. Chicago, IL: Moody Press, 1999.

Zimmerman, Martha. Celebrate the Feasts of the Old Testament in Your Own Home Church. Minneapolis, MN: Bethany House Publishers, 1981. 
NAME: $\quad$ Nelson Fernando de Oliveira Junior

DATE OF BIRTH: 21 December 1959

PLACE OF BIRTH: Montes Claros, MG, Brazil

WIFE: Nilma Najla Will de Oliveira

CHILDREN: $\quad$ Neander Will de Oliveira

Narlon Will de Oliveira

CREDENTIAL: Ordained a Seventh-day Adventist Minister

Rio Grande do Sul Conference

November 1989

EDUCATION:

1984 Bachelor of Theology, Instituto Adventista de Ensino, SP, Brazil

1984 Bachelor of Religious Education, Instituto Adventista de Ensino, SP, Brazil

1998 Master of Divinity (equivalency), Andrews University, MI, USA

2002 Doctor of Ministry, Andrews University, MI, USA

DENOMINATIONAL SERVICE:

1985-1985 School and Associate Pastor in Goiânia, GO, Brazil 1986-1986 District Pastor in Formosa, GO, Brazil

1987-1987 District Pastor in Vila Nova, Goiania, GO, Brazil

1988-1989 District Pastor in Sarandi, Porto Alegre, RS, Brazil

1990-1991 Youth and Music Director, South Parana Conference, PR, Brazil

1992-1996 Youth and Music Director, Sao Paulo Conference, SP, Brazil

1999-1999 Associate Pastor in Mountain View Church, Las Vegas, NV, USA

2000- District Pastor in Provo, UT, USA 